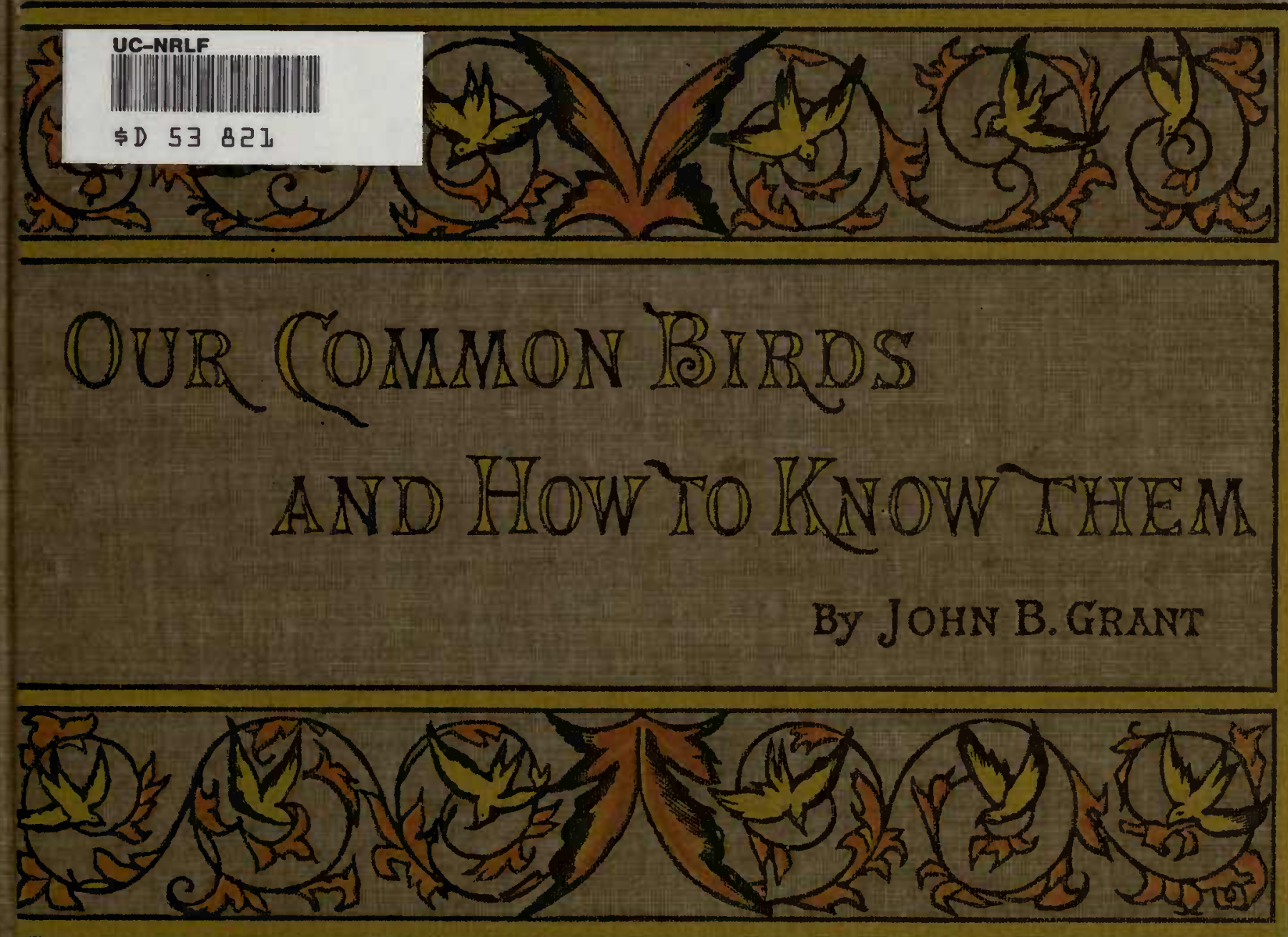


The Gift of Beatrix Farrand to the General Library

University of California, Berkeley

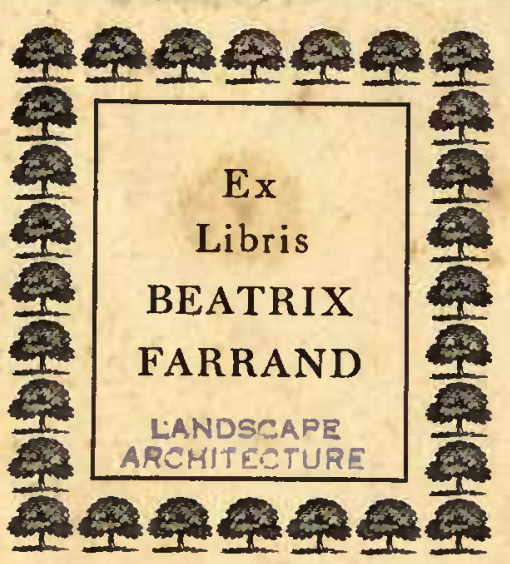

REEF POINT GARDENS

LIBRARY 


\title{
OUR COMMON BIRDS
}

\section{AND HOW TO KNOW THEM}

\author{
BY \\ JOHN B. GRANT
}

WITH SIXTY-FOUR PLATES

FOURTH EDITION

NEW YORK

CHARLES SCRIBNER'S SONS

1893 
Copyright, $189 \mathrm{I}$, BY

CHARLES SCRIBNER'S SONS

Press of J. J. Little \& Co. Astor Place, New York

\section{LANDSCAPE}




\section{INTRODUCTION}

IN offering this little book to the public, the author desires to disclaim great scientific knowledge of birds and their ways, his object being not so much to impart information, as to point his readers to the way of acquiring it for themselves. He believes, indeed, that by reason of his own experience, recent and consequently fresh in his memory, he is fitted to make some suggestions, particularly looking toward the economy of time and labor, which will be of value to the beginner in the art of observing birds. He thinks also that, in view of such measure of proficiency as has been attained by him, he can give encouragement by the promise of ultimate success, thus affording cheer to the student, and it may be preventing the abandonment of a study, which, if persevered in, cannot fail to increase the substantial enjoyment of all out-of-door life.

Doubtless, the beginner who has no friend learned in Natural History to counsel him, but is dependent wholly upon the books for guidance and his own untrained observation for facts, will experience certain discouragements. It will seem to him that if he reads up on any one bird and then sets out to find it, that particular variety will be the one which by no chance will he be able to meet with on his immediate excursions ; 


\section{Introduction}

while other kinds, unknown to him, will swarm about him. And, if he reverses the method, and singles out a specimen from those he does find, noting its markings, song and habits, with the intention of subsequently identifying it in the written descriptions, it will similarly appear to him that either such peculiarities as he has observed appertain equally to several varieties, or, worse still, if the books are to be trusted, they belong to none at all. Hence, whichever way he turns the result is the same-many birds seen but none identified.

This is, indeed, a serious dilemma, sufficiently embarrassing and disheartening; but it is to the student arrived at such a despondent frame of mind that the writer hopes to be of use, both with his advice and by means of the plates herewith presented.

As for the advice, though of the simplest, it is believed that it will prove effective. It will be given in detail in the following pages; but the most important, if the least startling features of it, may be here briefly stated.

Study one bird at a time.

Begin with the commonest, that is, the most abundant and most easily recognized ones; it is the province of this book to point such out. 


\section{Introduction}

Do not attempt, at the commencement, to identify any bird which presents puzzling characteristics, or rather any which does not present some striking mark either of song or plumage to serve as a sign for certain classification.

If these rules are observed, discouragements will be avoided, and progress will be realized more rapid than might at first thought be expected.

Regarding the plates, it may be observed that these not only afford the writer his principal hope of aiding the learner, but they serve as his chief excuse for this little volume. Many books have been written about birds, and by those, too, far more learned upon the subject than the present writer is. Reliable and handsome plates also have been published. But the books have either been of a purely literary character, delightful indeed to read, but conveying no detailed instruction to the beginner, or so voluminous and scientific as to repel him who desires only a naming acquaintance with such birds as he constantly sees. The plates thus far published have been in a form so bulky as to forbid their being carried into the field for use, and so expensive as to prevent many from ever owning them.

The plates presented in this volume are photographs of specimens mounted by an 


\section{Introduction}

expert taxidermist, ${ }^{*}$ which represent the birds in characteristic attitudes, sometimes modified, however, to positions best calculated to display plumage marks. Of course, the absence of color will be regretted. But colored plates are costly, and the object here has been to make an inexpensive book. Photography cannot, as yet, reproduce color, but it may, aided by description, indicate it.

Ninety specimens have been selected and described, all of them males, and all representing varieties so abundant that any person may surely find them if he chooses to seek. Of these birds, sixty-four portraits have been given. The descriptions, it is hoped, will be found to be trustworthy, although there is no pretense in them of exhaustive detail. The aim has been to furnish sufficient data to serve the purpose of identification, while avoiding the danger of confusion. The book has been put into such form as to be conveniently taken into the field for the learner's use, while he is actually regarding the living bird. It is not expected to take the place of a larger Manual, but to be supplementary to such a work. A complete Ornithological Treatise is a desirable possession for the bird-lover from the start, and it will become gradually indispensable to him as he grows in knowledge

* J. Wallace, 16 North William St., New York City. 


\section{Introduction}

and desires fuller and more detailed information than a small volume such as the present one can supply.

The birds which have come under the author's own observation, and whose habits are here recorded, were seen on Long Island, near Flushing, and at various points upon the Hudson River between New York City and Peekskill ; and in this connection it must be borne in mind that birds' habits vary greatly in different localities, so that absolute conformity to customs mentioned here must not in other places be invariably expected. Thus, to mention a single example, birds which, in one part of the country, nest upon the ground, may, in another part, be found building in trees.

Until a comparatively recent dite, no universally accepted system of bird nomenclature has been in vogue. Naturalists have, perhaps, not always been wise in the names they have bestowed upon the several varieties, and their successors have not hesitated to christen again and again according to their supposed better judgment or knowledge. It therefore came to pass that a bird could have several scientific, that is, Latin names, and it was even necessary in some instances, when making use of one of them, to append the name of the man who had applied it, to indicate with certainty what bird was meant. 


\section{Introduction}

This state of things naturally created considerable confusion-a confusion which must unfortunately continue to exist in all our bird literature antedating in publication the year 1885 .

In that year the American ORNITHOLOGIST'S Union adopted a Code of Rules, and issued a Check List prepared by a committee appointed by the Society. This document was compiled with so much learning and conservative wisdom, that its authority has been recognized by most if not all ornithologists and its nomenclature adopted. The arrangement and nomenclature of this List have been followed as a matter of course, in the present book, so far as the Latin names are concerned. In regard to the common names of birds, however, which are in no sense scientific, the author has frequently allowed himself to make use of those which seem to him more familiar. For example, Pine Finch instead of Pine Siskin, Indigo-bird instead of Indigo Bunting, Red Crossbill instead of American Crossbill, etc., etc.

Many books have been consulted to correct or confirm the author's own statements ; likewise to furnish authority for the descriptions appertaining to a small number of specimens which he has not seen in life, but which, for the sake of completeness, he 


\section{Introduction}

has thought it best to include in his list. Two of these works require special mention, because of the liberal use made of them. They are Dr. Elliott Coues' KEY TO NORTH American Birds, and A list of the Birds of the Hudson Highlands, by Dr. Edgar A. Mearns. The measurements of birds given in the latter of these works have, with slight modifications, been adopted here. The figures are the average lengths of from half a dozen to about half a hundred specimens, and may serve as a general indication of size. Dr. Mearns' List is the source also from which most of the dates of migration have been taken.

It should also be said that the idea of a calendar of bird arrivals and departures is not an original one. Dr. Allen published a somewhat similar list of New England birds in the first volume of the American Naturalist, issued in 1867-8.

Thanks for assistance are due to Mr. E. A. Fairchild, Principal of the Flushing Institute, and to Mr. Clifford Smyth, of New York City.

To Dr. J. A. Allen, Curator of the Ornithological Department of the Museum of Natural History of New York City, the author is particularly indebted for kindly advice and much valuable help in various ways. 
Our Common Birds and How to Know Them 
"Whan shaws beene sheene, and shraddes full fayre, And leaves both large and longe,

Itt's merrye walkyng in the fayre forrèst

'To heare the small birdes songe."

-Ballad of Robin Hood and Guy of Gisborne. 


\section{OUR COMMON BIRDS AND HOW TO KNOW THEM}

THE equipment necessary for an observer of birds is not large. He needs only a pocket note-book, a good opera or field glass, stout and easy boots or shoes and clothing of strong texture and inconspicuous color; these for the field. For the study he must have a good book of reference (there is none better than A KEY TO THE BIRDS OF NORTH AmERICA, by Dr. Elliott Coues), and a journal. The notes made during a ramble will, of course, be hasty, incomplete, in short mere memoranda ; but the transcriptions of these into the journal should be elaborated with care, and in the best literary style possible. This journal will be frequently read, both by its writer and probably by his friends, and it may with great likelihood form the basis of future publication. Moreover, it should be written out as soon as possible after the excursion whose results are to be recorded, and while the observations regarding markings and habits of specimens remain clear in the memory; for, if this be not systematically done, and if the notes of several days' ramblings be allowed to accumulate, it is more than likely that there will be a confusion of the facts beyond the power of the field book to disentangle. 


\section{Our Common Birds and How to Know Them}

But if the would-be observer looks forward to what may be called professional work, and intends to make an exhaustive study of ornithology. he must kill birds and learn to skin and preserve them; and for this purpose he must have a gun and a set of taxidermist's instruments. Dr. Coues, in his KeY, gives full directions regarding the use of these, together with ample instruction in the formation and care of a collection. In the present little work this branch of the subject will not be discussed, and only such familiarity with birds will be sought for as may be attained by observation alone and through the instrumentality of no weapon more deadly than the opera-glass.

Armed, therefore, with opera-glass and note-book, start out in the early morning or towards sunset. It is at these times during the summer season, that birds are active. In the heat of the day, no observations can be made of sufficient importance to repay the personal discomfort and even risk which exercise at such a time involves. The few hours immediately succeeding day-break are best of all, but for obvious reasons a somewhat later period will be chosen by most people, and indeed there is enough occurring for quite a large portion of the morning to repay the watcher. After all, the occupation 


\section{Our Common Birds and How to Know Them}

is undertaken for recreation, and let him to whom early rising is an abomination, in the name of Morpheus, slumber on ; only, when his tardy start is effected, he shall not witness bird-life so exuberant, nor listen to such floods of melody, nor inhale such richness of perfume, nor find refreshment in airs so balmy, as he might have done had he been earlier astir.

In Spring and Fall, however, the conditions are somewhat different, and mid-day walks may well be productive of good; while in Winter they are sometimes best of all.

When exploring open country, such as field and meadow, walk briskly. Here you cannot hope to steal up to your bird and study him, yourself unobserved. The most you can do is to come upon him suddenly, mark the spot whence he starts that his nest may be searched for ; note his manner of flight, getting at the same time such details of plumage as may be possible, and perhaps stalk him in the tree or thicket where he has taken refuge. And this stalking must be deftly done. Approaches must be accomplished by detours, with advantage taken of trees, bushes, rocks and mounds for partial concealment. Nor may you push your investigations too far ; a bird's quickness of sight and hearing is remarkable, and its dislike of inspection a universal 


\section{Our Common Birds and How to Know Them}

trait. It is also surprisingly clever in discriminating between the casual wayfarer who is oblivious of its presence, and him who comes to spy upon its privacy.

Therefore, your hunting must be full of lndian-like craft and subtlety, and your standpoint for observing chosen with good judgment. But, should it happen, as too often it will, that the bird you are following is unusually shy, and you feel doubtful of being able to attain a sufficiently near position, artifice may still enable you to carry out your design. Throw off now all appearance of stealth or watchfulness, and, assuming the guileless and unconcerned manner of the purposeless loiterer, stroll along, not too directly towards the bird, and particularly avoid any steadfast gazing. Duplicity of this sort will frequently outmatch your adversary's sagacity, and should be practiced in its proper time.

Another expedient for retarding a bird's too hasty departure, sometimes adopted with success, is to give utterance to sundry chirps and whistles to which you will endeavor to impart some resemblance to bird-language. It is a fact, unlikely as it may seem, that a bird will often remain to answer, and will sometimes even approach quite near to the accomplished mimic. 


\section{Our Common Birds and How to Know Them}

When wandering in woods or groves, tactics of another sort should govern your proceedings. Here you may confidently expect to surprise many a bird, and therefore you should go slowly, with your attention given mostly to the tree-tops, quick to notice and investigate each motion among the branches, and with ears alert for every chirp or twitter. In such a place, you will, perhaps hear the chatter and see the bright eyes or bushy tail of the saucy squirrel. Fur or feathers, quills or scales, all creatures will be objects of interest to you even from the beginning of your investigations, while their importance will intensify as increase of knowledge is obtained.

When you have come upon a bird, of course your opera-glass will be put to use. But even in raising it to your eyes your movement should be deliberate. Never forget that a hasty motion or the quick glancing of the sun upon the barrel or lens of the glass is sufficient to betray your presence. Now that you are watching your specimen, it might, perhaps, seem that your end is attained and that no further special qualifications are needful for what remains to be done, the simple act of observation. Not so; your observing faculties must be trained before good results can be assured. It is not sufficient that you see in a merely superficial way; you must be capable of detecting special and 


\section{Our Common Birds and How to Know Them}

distinctive peculiarities, and the ability to do this comes to few except through training. The bird's markings should be carefully studied; the tail and wings should be noted, whether they be long or short, slender or full, and whether the former be rounded, square or notched; the tints of bill and legs should be remarked; attention should be given to characteristic habits, such as the flight, whether straight or undulatory ; the position maintained in the tree, whether high or low in the branches; the general deportment, whether restless or composed ; the nature of the environment, whether marsh, meadow, wood, upland or lowland; and above all, the song or note of the bird should be so thoroughly learned that it will be instantly recognized when again heard. These and a host of other observations of a kindred nature should be diligently made and faithfully transcribed in your note-book. They will assist you greatly, not only in determining the species when you have opportunity to consult your reference book, but, if you chance already to know the individual, they will strengthen former records of its habits, not unfrequently show variations either before not remarked or peculiar to locality, and will always tend to increase your intimacy with the bird.

During the actual inspection of a specimen, it is usually unadvisable to withdraw 


\section{Our Common Birds and How to Know Them}

one's eyes for the purpose of making memoranda, since, if one loses sight of a bird, it is frequently difficult to regain it. Before the next specimen is sought, however, the notes descriptive of the one just observed should habitually be made, and that too, be it remembered, with the thoroughness which has already been strenuously advised. Depend upon it, the time and trouble bestowed upon these notes will be certainly and speedily rewarded.

A third, and for an indolent nature an extremely pleasant, method of studying birds is to seek some spot which possesses peculiarly attractive features for them, and whither they are accustomed to resort in great numbers, and there, properly sheltered, seat yourself and quietly wait for what may come within the range of your vision. I have in mind two localities that have always proved wonderfully rich in bird-life. One is a bluff, perhaps forty feet in height, rather steep, and with a number of good-sized forest trees growing upon its slope. Rolling fields spread backwards from its brow, and at its foot runs a line of shrubbery, somewhat thicket-like in character and forming a sort of natural hedge, which fittingly bounds a boggy meadow beyond. Several small springs issue from the sides of this declivity and trickle down in gentle streams until lost in the 


\section{Our Common Birds and How to Know Them}

ditches which intersect the meadow. Meadowlarks, Blackbirds, Marsh Wrens, Bitterns, Bobolinks and an occasional Duck frequent the lowland. In the upland, the Cowbird, the Robin and the Song Sparrow disport themselves; into the trees and shrubs upon the bluff come Woodpeckers, Thrushes, Orioles, Catbirds, Flycatchers and Warblers, and all of these, and, indeed, more than I have named, take turns in visiting the springs and rivulets; now indulging in a hasty bath, now daintly slaking their thirst, now breaking forth into song, now making love, and now, must it be confessed, waging war, all utterly unconscious of the observer, who, reclining upon a mossy bank, or sitting . motionless upon a log or stump, or leaning fixedly against the trunk of some friendly tree, is watching with intense interest the scenes of sylvan life unwittingly enacted before him.

Such is one of the favored spots. The other is an old, deserted and gone-to-ruin apple orchard, far from any habitation, except a few scattering farm-houses. This orchard is skirted on three sides by forest trees, and on the remaining side by a swamp, which is a tangle of alders and other water-loving growths. Here may be seen the Orchard Oriole, the Black-billed Cuckoo, the Indigo-bird, the Summer Redbird, the Towhee, the 


\section{Our Common Birds and How to Know Them}

Redstart, the American Goldfinch, Wrens, Thrashers, Vireos, and numerous other varieties of birds in great profusion. It was at this place that a friend of the writer pitched a tent, and, with his dog as his only companion, spent four delightful months, solitary, indeed, except for an occasional visit from a few of his acquaintances who were lovers enough of Nature to be willing to accept in her service the limited, but by no means comfortless, accommodations of a canvas house and a somewhat rudimentary couch. It was the writer's good fortune to be reckoned among the favored ones, and the days spent there in delightful rambles and the evenings passed in luxurious repose will linger long in the memory.

Here I made my first acquaintance with the Black-billed Cuckoo. It was at dawn, or shortly after. We were wakened by a loud and continuous and rather hoarse cooing note. We rose and stole out of the tent, and upon the large tree, whose branches overhung our habitation, sat a long, grey bird, with a light breast. It looked somewhat like a Pigeon, and, indeed, its utterance bore a certain resemblance to the croon of that bird. It was not long, however, before we knew it to be the Cuckoo, and we stood and watched it with interest for many minutes. After a time we perceived several 


\section{Our Common Birds and How to Know Them}

others of its companions noiselessly flitting among the branches of some adjacent trees, and our first friend finally joined these and all departed.

Doubtless, there are specially favored spots in every region, where the observer will meet with the objects of his search in greater variety and profusion than in other places, and to him who once becomes attentive to ornithological pursuits, they will speedily become well-known and favorite resorts. Mr. Burroughs, a constant observer and a charming writer, tells of a certain hemlock wood where, during one ramble, he counted "over forty varieties." But it is not essential that multitudes of birds should be present to render the occupation of the student attractive. In fact, it is not certain that too great a variety would not be a means of confusing the beginner. His attention would possibly be diverted from one specimen to another with such rapidity that he could not sufficiently familiarize himself with any. Certainly, the closest observers have never made it a matter of complaint that objects for study were not at hand. Mr. Bradford Torrey, either from necessity or choice, made the Common in the City of Boston a field for his study of birds. One would say that this was not a promising site. In fact, Mr. Torrey admits that the place is not an ideal one for such a purpose, though in justice 


\section{Our Common Birds and How to Know Them}

to him, it must be stated that it is not of the scarcity of objects that he complains, but of the publicity of the situation. He says: "Other things being equal, a modest ornithologist would prefer a place where he could stand still and look up without becoming himself a gazing-stock." Nevertheless, Mr. Torrey did "stand still and look up," and to good purpose, too. He says : "Within the last seven or eight years 1 have watched there some thousands of specimens, representing not far from seventy species." That is what it is to have the love of observing and to know how to exercise it. The ordinary citizen of Boston passes through the Common every day of his life noticing only English Sparrows, and perhaps a few Robins. But Mr. Torrey finds " not far from seventy species," among them birds most unlikely to be in such a place, as the Butcherbird, the Sapsucker, the Maryland Yellow-throat, the Cuckoo, the Kingfisher and the Owl, not to mention a Mockingbird, a Cardinal Grosbeak and a Paroquet, which he guesses to be escaped cage-birds.

Gilbert White's researches were confined to the single parish of Selborne in the county of Hampshire, England; and his diaries and letters to his friends, "Thomas Pennant, Esquire," and "The Honorable Daines Barrington," in which he discusses and 


\section{Our Common Birds and How to Know Them}

comments upon the quadrupeds, birds, insects, worms, vegetables, weather and antiquities of his parish, have been the delight of succeeding generations of readers, whether naturalists or simply cultivated people of no especial calling.

"I find," he writes, "that that district produces the greatest variety which is the most examined;" a significant remark, and, coming from a past-master in his art, worthy of full credence. We may, therefore, be assured that whatever place we are in will be found to offer full scope for studies in natural history. All that need concern us is lest we ourselves fall short in requisite diligence.

It has been intimated that special training, if not special faculties for precise observation are needful to make one a really good observer. Henry D. Thoreau may be cited as a type of this sort of student, and though his personal character may repel one by reason of its intense egotism; and though one be constantly excited to resent the scorn with which he regarded his fellow-men and which he did not hesitate to express; still his reverent love of nature must produce sympathy, and his untiring energy in the pursuit of a knowledge of her secrets must command respect, while the contemplation of his life and work must always be of use to a person engaged in similar research. 


\section{Our Common Birds and How to Know Them}

Thoreau had the faculty of quick and accurate observation to a most extraordinary degree. Emerson, in a biographical sketch of him, says: "He noted what repeatedly befell him, that after receiving from a distance a rare plant, he would presently find the same in his own haunts. And those pieces of luck which happen only to good players happened to him. One day, walking with a stranger who inquired where Indian arrow-heads could be found, he replied, 'Everywhere,' and, stooping forward, picked one on the instant from the ground. At Mt. Washington, in Tuckerman's Ravine, Thoreau had a bad fall, and sprained his foot. As he was getting up from his fall, he saw for the first time the leaves of Arnica mollis."

Read in his journals how he chronicles the reddening of the maple buds, the first appearance of the skunk-cabbage, the earliest note of the tree-frog, the arrangement of the sand upon the rail-road embankments in tiny ridges caused by showers of rain. Nothing is too trivial to escape him, and there is nothing that does not secure the interest of his reader also when once pointed out and commented upon in his own happy manner.

Not every one may hope to equal White or Thoreau. Few people have either their talent or the leisure for its exercise. But there are many, nevertheless, whose love of nature 


\section{Our Common Birds and How to Know Them}

is similar in kind if not in degree to that which dominated them. Some of these, who are now simply conscious of a general, undefined feeling of pleasure when contemplating a charming view, and who, when brought by chance into contact with a bird or an animal in its native haunts, experience only a momentary interest and admiration at the sightsome of these (and more, perhaps, than are themselves aware of any such predilection) are fitted to share that glorious thrill and glow which nature bestows with liberal hand upon her devotees. If they have not already felt that delight it is only because they have hitherto slighted her.

Let us suppose a person of this kind ; one, susceptible indeed to rural delights, but engrossed in other affairs, and hitherto inattentive to natural incidents or objects. Let us suppose some such incident or object to be thrust upon his sight in a way strongly to attract his notice. Say that upon one of his rambles he finds a bird's nest containing a complement of eggs, and is struck with the cleverness of the structure and the beauty of its fragile contents. Can we not perceive that here may be the starting-point from which he will become an accomplished observer? And may we not easily fancy the succeeding steps of his progress? His curiosity is roused, and he takes his station near by 


\section{Our Common Birds and How to Know Them}

to await the coming of the owner of the nest. He is not long delayed, for he soon discovers that yonder little bird, flitting and chirping in the adjoining thicket with manifest uneasiness must be the one he seeks. After some time spent in watching, he departs, only to come next day and the next, until the eggs have given place to young birds; and now he has attained such dexterity of approach that he is able to come near enough, himself undetected, to witness the parents as they feed their fledglings. One day he arrives when one or more of the young birds essay their first flight. But long before this he has found means to inform himself of the species of the birds he is studying, and he is well on the way to become a bird observer. Indeed it maly be confidently asserted that he has not confined his interest to this single group. Led on by that pleasurable initial experience, he has noticed many other birds and has to some degree studied their actions too. He has learned the songs of some kinds, he has seen them feeding, he begins to know in what places to look for certain varieties, and at last he discovers that his acquaintance not only with birds, but with insects, quadrupeds, plants and trees has become considerable, and he is forced to acknowledge that all nature has taken on a new aspect for him. Moreover, his daily enjoyment has enormously increased, in that his resources have been multiplied 


\section{Our Common Birds and How to Know Them}

and his capacity to comprehend has been enlarged, while his health, by reason of abundant out-of-door exercise, and in consequence of the relaxation which comes from a diversity of agreeable pursuits, has received great benefit.

It hals been thus with many who have been led on by insensible degrees, until they have attained considerable proficiency in natural lore; and so it will doubtless be with many more ; and while it is not to be expected that every one who desires an intelligent understanding of the subject will aim to become a learned scientist, still it is desirable that every one should start in the right direction and then the point to which he will arrive may be salfely left to the determination of the many circumstances and conditions which govern the conduct of each individual.

Concerning that branch of natural history termed Ornithology, which we are here briefly considering, three methods of procedure have been indicated and advice has been given concerning each. In the first two, the student walks through woods and forests, and in open fields and meadows. In the last he is seated at ease in some favorable spot known to be inhabited or frequently visited by birds. And while it has been pointed out that each of these methods requires different treatment, it has been assumed that all of them 


\section{Our Common Birds and How to Know Them}

will be practised, since they are all not only dependent upon each other, but are also equally valuable in their results and delightful in their prosecution. The discussion has been slight, but sufficient, it is believed, in connection with the few words of advice which follow to start the novice upon the right way.

Cultivate a noiseless footfall, and avoid jerky movements. Choose firm, turfy ground when possible, shunning gravel that crunches, sticks that snap, or leaves that rustle. Proceeding through bushes and undergrowth, part the branches softly and release them with care, that they may not fly back and by their swaying alarm the birds. Train your ear to catch every sound and to note its source, not allowing a chirp or twitter to escape you or to remain unexplained. Accustom your eye to mark every movement, teaching it to discriminate betwixt the wind-stirred leaf and that set in motion by bird or squirrel. All this, with practice, will become more and more easy until it will be accomplished mechanically - then, a chirp, which once would not have been heard at all, or if by chance noticed, would have conveyed no information beyond the simple fact that some unknown bird, insect, or, it maybe, toad, was in the branches of yonder tree, will now tell you what the creature is and allure you to investigations of delightful interest. 


\section{Our Common Birds and How to Know Them}

But be patient. Do not expect to learn immediately all there is to be known. And do not try to identify too many kinds of birds at the commencement of your career. Choose for your earlier studies those that are at the same time abundant and that are striking in plumage or song, or both; confining yourself to male birds, that is to say, to precisely those which alone as a rule possess these well-marked characteristics. For if you puzzle over each bird you see, and with all your pains fail to become satisfied as to its identity, you must be a person of uncommon perseverance, if you do not soon grow disheartened.

You now probably know the Robin and the Crow. Who does not? Well, begin with these. Study them. They alone, if really studied, are capable of affording much entertainment. As for the Robin you need not leave the precincts of your own garden to find him. But there are other birds probably not known to you, and yet always present in great numbers, which you may immediately add to your list for present study; confident that after reading about them in the books you will recognize them on sight; or even should you chance to meet them without preparation that you will be able to identify them by subsequent reference to the books. They are the Red-winged Black- 


\section{Our Common Birds and How to Know Them}

bird, the Catbird, the Thrush (at first you will not be able to say which one of the Thrushes), the American Goldfinch, the Baltimore Oriole, the Cuckoo, the Flicker, the Hummingbird, the Indigo-bird, the Bobolink, the Meadowlark, the Scarlet Tanager, the Bluebird, the Summer Redbird, the Blue Jay, the Chickadee, the Kingfisher, the Chimney Swift, the Barn Swallow, the Owl and Woodpecker (perhaps the particular kind of these last two will puzzle you), the House Wren, the Cedarbird, and, after you have learned the song, the Song Sparrow.

This is no mean catalogue, and, when you have become familiar with the birds comprising it, you will feel that you have added to the number of your acquaintances a very goodly company. But before this is accomplished, and it will not require a long time to do it, you will have unconsciously learned to know many less easily distinguished birds among the Flycatchers and Warblers, not to mention some of the more soberly attired partners of those birds which have been mentioned.

In selecting such al list as hals been given however, it must be borne in mind that some of these birds vary in color according to the time of year. The Bobolink, for example, in Spring and Summer is strongly marked with white, black and buff, while in 


\section{Our Common Birds and How to Know Them}

the Fall he becomes streaked with different shades of brown. The American Goldfinch in Summer is bright yellow with a black crown ; in the Fall the black on his head disappears and the yellow of his body fades to a pale brown. And the Indigo-bird does not attain to his full brilliancy of plumage until he has been with us some time. The books, however, will apprise you of such changes and no serious trouble on this score need be apprehended.

Prepare for yourself, therefore, a list somewhat similar to that which has here been given of easily distinguished birds which you may expect to meet, and seek and study them. When you see a brown, plainly marked bird, observe it indeed, and even transfer what you may of it to your note-book, but do not puzzle too long in the attempt to name it. Close your memoranda by writing "name unknown." Rest assured that your knowledge will surely augment, and such entries will occur less and less frequently. It is interesting and oftentimes helpful to consult colored plates. But owing to the great expense of really good ones, not everybody can do this. An extremely good plan is to make an occasional visit to the institutions where stuffed specimens are kept, such as the various museums of natural history. Here it may easily happen that a glance will set at rest doubts that a long period of field or book study will fail to solve. 


\section{Our Common Birds and How to Know Them}

The suburban dweller, who is able to continue his observations through every month of the year, will have the privilege of watching the coming and going of the birds in their migrations, and, knowing the periods of these, will be enabled to inspect each species as it arrives, forewarned, so to speak, of the name of the particular bird he may expect to see. The great advantage that an observer so circumstanced will possess over him whose country life is limited to a few months of the Summer, when the birds are present in bewildering confusion, is obvious. The celebrated scientist, John Tyndall, when illustrating in a lecture on Sound the value of previous information concerning what was to be expected from an experiment, relates an incident in his acquaintance with Faraday. He says: "I had everything arranged, when, just before 1 excited the magnet, he laid his hand upon my arm and asked, "What am 1 to look for?". And then he adds that even "that prince of experimenters felt the advantage of having his attention directed to the special point in question." Just so it is with the student of birds. When told that the Song Sparrow arrives early in March; that it is streaked above with red and brown; that it has a chestnut crown; and that its song is "one high note thrice repeated and then a canary-like cadenza ;" and when early in March he hears such a song, and, 


\section{Our Common Birds and How to Know Them}

detecting the singer, remarks that its appearance corresponds with the above description, he entertains no manner of doubt that it is the Song Sparrow which he is regarding.

Again : he is told that the Bluebird comes also early in March ; that the upper part of its body is blue, its breast reddish, its belly whitish; and its song is "al soft, pleasing warble, uttered both when flying and when at rest." When at such time he meets such a bird, there can be no room for mistake in its identification.

The opportunity for watching the coming and going of the birds is indeed most advantageous for the student, and a calendar of their arrivals and departures is here appended.

During the months of January and February the following birds are usually to be found. though few of them are numerous, while in severe winters the greater part will probably be driven southward: White-throated Sparrows, Chickadees, White-bellied Nuthatches, Winter Wrens, Cedarbirds, Shrikes, Golden-crowned Kinglets, Horned Larks, Pine, and Purple Finches, Juncos, Snow Buntings, Crows, Blue Jays, Kingfishers, Red Crossbills, American Goldfinches, Meadowlarks, Hoot Owls, Screech Owls, Snowy Owls, Saw-whet Owls, Hairy, and Downy Woodpeckers, Flickers, Robins and Bluebirds. 


\section{Our Common Birds and How to Know Them}

March

1 to 10 Robins, Bluebirds and Song Sparrows come in small numbers.

10 to 20 These become more plentiful, and Purple Grackles and Red-winged Blackbirds appear. Purple Finches and Flickers receive accessions, and Fox Sparrows may be seen on their northward migration.

Snowy Owls retire nortbward.

20 to 31 All these become still more numerous, Meadowlarks are recruited, and Phobes and Vesper Sparrows begin to come.

Pine Finches, Horned Larks, Snow Buntings and Shrikes go north.

April

1 to 10 Kingfishers are recruited. Red-headed Woodpeckers pass. Myrtlebirds and Ruby-crowned Kinglets appear, though these go farther north in a few weeks. Yellow-bellied Sapsuckers, Cowbirds and Hermit Thrushes arrive. 


\section{Our Common Birds and How to Know Them}

April

10 to 20 Palm Warblers pass. Field Sparrows and Chipping Sparrows come.

Red Crossbills leave for the north.

20 to 30 White-throated Sparrows, Chewinks, Chimney Swifts, Brown Thrashers and House Wrens appear.

Winter Wrens go nortb. Most of the Fox Sparrows bave passed.

May

I to to Whip-poor-wills, Catbirds, Barn, and Bank Swallows, Kingbirds, Oven-birds, Wilson's Thrushes, Wood Thrushes, Blue Yellow-backed Warblers, Yellow Warblers, Black-throated Blue Warblers, Black and White Warblers, Chestnut-sided Warblers, Solitary Vireos, White-eyed Vireos, Yellowthroated Vireos, Redstarts, Grasshopper Sparrows, Rose-breasted Grosbeaks, Baltimore Orioles, and Yellow-breasted Chats arrive.

Juncos and Golden-crowned Kinglets go nortb. Ruby-crowned Kinglets also" resume their nortbward flight. 


\section{Our Common Birds and How to Know Them}

May

Io to 20. Magnolia Warblers, Bay-breasted Warblers, and Blackburnian Warblers may be seen on their northern migrations. Bobolinks, Orchard Orioles, Redeyed Vireos, Wood Pewees, Scarlet Tanagers, Maryland Yellow-throats, Black-throated Green Warblers, Worm-eating Warblers, Hooded Warblers, Cuckoos, Indigo-birds, Great Crested Flycatchers, Least Flycatchers and Hummingbirds come.

White-tbroated Sparrows leave for the north. Hermit Thrushes become less common, most of these also retiring nortbward. Myrtlebirds also resume their nortbward journey

20 to 31. Black-poll Warblers and Yellow-bellied Flycatchers pass, going north. Marsh Wrens appear, and one may hope for an occasional sight of a Cardinal Grosbeak.

During June, July and August the birds effect little change of locality, as nests have been constructed and the duties of incubation assumed. In many cases young birds have 


\section{Our Common Birds and How to Know Them}

entered into existence and by their immature and changing plumage have added to the difficulties which the unaccustomed observer has already had in identifying specimens. Indeed, unless the student has by this time made considerable progress in his acquaintance with birds, he will now experience that embarrassment which arises from a superabundance of material, and will find the number of birds present bewildering to classify, both because of the great variety and because of the dissimilarity of the male, female and young of each species.

Let him, however, not despair ; much may still be done by observation, and even from the order of their retirement specimens may be identified.

Sept.

I to 15 Wilson's Thrushes, Yellow-breasted Chats, Yellow Warblers, Hooded Warblers, Barn Swallows, Bank Swallows, Baltimore Orioles, Kingbirds, Whip-poorwills, and Hummingbirds now go south.

Blackburnian Warblers, Magnolia Warblers and Yellow-bellied Flycatchers pass on their southern migration. 


\section{Our Common Birds and How to Know Them}

Sept.

15 to 30 Wood Thrushes, Chimney Swifts, Yellow-throated Vireos, Redstarts, Wood Pewees, Great Crested Flycatchers, Rose-breasted Grosbeaks, Indigo-birds, Orchard Orioles, Worm-eating Warblers, Chestnut-sided Warblers, Cuckoos and Bobolinks follow.

Red-beaded Woodpeckers, Bay-breasted Warblers, Paln Warblers, Myrtlebirds and Ruby-crowned Kinglets pass, going south. Juncos arrive from the north.

Oct.

1 to 15 Hermit Thrushes, Grasshopper Sparrows, Marsh Wrens, House Wrens, Catbirds, Brown Thrashers, Red-eyed Vireos, Solitary Vireos, White-eyed Vireos, Cowbirds, Scarlet Tanagers, Black and White Warblers, Blue Yellow-backed Warblers, Black-throated Blue Warblers and Least Flycatchers go.

White-throated Sparrows pass. Golden-crowned Kinglets, Horned Larks, Pine Fincbes and Winter Wrens appear. 


\section{Our Common Birds and How to Know Them}

Oct.

15 to 31 Oven-birds, Maryland Yellow-throats, Song Sparrows, Chipping Sparrows, Field Sparrows, Phobes, Chewinks and Black-throated Green Warblers go ; so do the most of the Flickers, Purple Finches, and Yellow-bellied Sapsuckers. Nov. Fox Sparrows and Black-poll Warblers now visit us as they go south.

1 to 15 Purple Grackles, Vesper Sparrows, and Red-winged Blackbirds now go, also most of the Meadowlarks, Robins and Bluebirds ; leaving us our Winterresident birds.

Snow Buntings and Sbrikes arrive.

Just what prominence to give to the purely scientific phase of Ornithology in a book of the limited scope and modest pretensions of this one is not easy to determine. But that some attention should be bestowed upon this branch of the subject, seems advisable for several reasons. Continual reference is made in bird literature to family, species and genus, and a clear conception of just what these terms mean is essential to the reader. Again, even though a knowledge of the common names only of birds be all that is at first intended, the time will shortly arrive when the Latin name will be applied, and when this is done, the genus, the species, and sometimes the sub-species, is indicated by the simple 


\section{Our Common Birds and How to Know Them}

use of the name. The Latin name of the Hermit Thrush is Turdus aonalascbka pallasii ; Turdus being the genus, aonalascbka the species and pallasii the sub-species. Again, the Latin name of the Wood Thrush is Turdus mustelinus. Here Turdus is the genus, and mustelinus the species. And finally, when the Manuals and Keys are used in identifying specimens, some familiarity with scientific terms and nomenclature is absolutely needful for an intelligent perusal of the volumes.

It is thought therefore that these considerations justify the insertion of a few remarks of a somewhat scientific character.

Naturalists have arranged the kinds of birds in many divisions and sub-divisions. As an illustration of such arrangement Dr. Coues in his KEY gives the following example of the classification of one bird, namely, Alice's Thrush :

Kingdom, Animalia: Animals.

Branch, Vertebrata: Back-boned Animals.

Province, Sauropsida : Lizzard-like Vertebrates.

Class, Aves: Birds.

Sub-class, Carinate: Birds with Keeled Breast-bone.

Order, Passeres: Perching Birds.

Sub-order, Oscines: Singing Birds.
Family, Turdida: Thrush-like Birds.

Sub-family, Turdina: True Thrushes.

Genus, Turdus: Typical Thrushes.

Sub-genus, Hylocichla: Wood Thrushes.

Species, Ustulatus: Olive-backed Thrush.

Sub-species, Alicia: Alice's Thrush. 


\section{Our Common Birds and How to Know Them}

A scale of sixteen steps is recommended in the CODE of the American Ornithologist's Union as being "adequate to all practical requirements of even a refined system of classification."

It is as follows :
1 Kingdom.
5 Super-order.
9 Family.
13 Species.
2 Sub-kingdom.
6 Order.
10 Sub-family.
14 Sub-species.
3 Class.
7 Sub-order.
4 Sub-class.
8 Super-family.
II Genus.
15 Variety.
12 Sub-genus.
16 Individual.

It would indeed seem to a layman that these sixteen grades afforded sufficient scope for the classification of any ordinary bird.

All birds, whether living or extinct, belong to the Class Aves. In this Class there are five sub-classes, viz. :

SAURURT.

ODONTOTORMAE.

ODONTOLCE.
RaTITE.

Carinate. 


\section{Our Common Birds and How to Know Them}

The last two are the only ones of which there are living specimens and it is only concerning birds which belong to the last sub-class of all, that is Carinate, that we have here to deal.

Birds of this sub-class are characterized, besides other particulars, byThe keeled breast-bone,

A special adaptation to flight, and

The absence of teeth.

The sub-class Carinate is separated into the following Orders :

1 Pygopodes: Diving Birds.

2 Longipennes: Long-winged Swimmers.

; Tubinares: Tube-nosed Swimmers.

4 Steganopodes: Totipalmate Swimmers.

5 Anseres: Lamellirostral Swimmers.

6 Odontoglossæ: Lamellirostral grallalores.

7 Herodiones: Herons, Storks, lbises, etc.

8 Paludicolæ: Cranes, Rails, etc.

9 Limicolæ: Shore Birds.
10 Gallinæ: Gallinaceous Birds.

11 Columbæ: Pigeons.

12 Raptores: Birds of Prey.

13 Psittaci : Parrots, Macaws, Paroquets, elc.

14 Coccyges: Cuckoos, etc.

15 Pici: Woodpeckers, Wrynecks, etc.

16 Macrochires: Goatsuckers, Swifts, etc.

17 Passeres: Perching Birds 


\section{Our Common Birds and How to Know Them}

And into the following sub-orders :

I Podicipedes: Grebes.

2 Cepphi: Loons and Auks.

3 Ibides : Spoonbills and Ibises.

4 Ciconire: Storks, etc.

5 Herodii : Herons, Egrets, Bitterns, etc.

6 Grues: Cranes.

\% Ralli : Rails, Gallinules, Coots, etc.

8 Phasiani : Pheasants, Grouse, Partridges, Quails, elc.

9 Penelopes: Curassows and Guans.

1o Sarcorhamphi : American Vultures.
11 Falcones: Vultures, Falcons, Hawks, Büzzards, Eagles, Kites, Harriers, etc.

12 Striges: Owls.

13 Cuculi : Cuckoos, etc.

14 Trogones: Trogons.

15 Alcyones: Kingfishers.

16 Caprimulgi : Goatsuckers, etc.

17 Cypseli : Swifts.

18 Trochili : Hummingbirds.

19 Clamatores: Songless Perching Birds.

20 Oscines : Song Birds.

And these, again, into sixty-six families and forty-six sub-families, and into genera, species and varieties to a bewildering extent.

There are about one thousand kinds mentioned in the CHECK LIST of the American Ornithologist's Union, some of which are not properly North American Birds; and Dr. Coues in his KeY describes nearly nine hundred varieties, including birds like the Skylark, 


\section{Our Common Birds and How to Know Them}

which, he says, "occurs as a straggler from Europe in Greenland, and also, it is said, in Bermuda and Alaska,"-and the Great Auk, of which he writes, "It seems very improbable that the species lived down to 1870 ," having "lost the use of his wings and perished off the face of the earth in consequence."

It is not likely that the unprofessional observer will meet with one-quarter of this number. Indeed, three hundred kinds would be a great many to be.observed by the most enthusiastic and diligent professional ornithologist in any one locality.

The birds forming the little collection described in this book, are embraced under live of the Orders, viz. :

Raptores, Coccyges, Pici, Macrochires and Passeres, and belong to the following families:

$\begin{array}{ll}\text { Bubonidx. } & \text { Trochilidx. } \\ \text { Cuculida. } & \text { Tyrannidx. } \\ \text { Alcedinidx. } & \text { Alaudidx. } \\ \text { Picidx. } & \text { Corvidx. } \\ \text { Caprimulgidx. } & \text { Icteridx. } \\ \text { Micropodidx. } & \text { Fringillidx. }\end{array}$

Tanagridæ:

Hirundinidxe

Ampelidie.

Laniidæ.

Vireonidx.
Mniotiltidx.

Troglodytidx.

Paridx.

Sylviidæ; and

Turdidie.

They are representatives of eleven sub-families and number ninety individuals. 


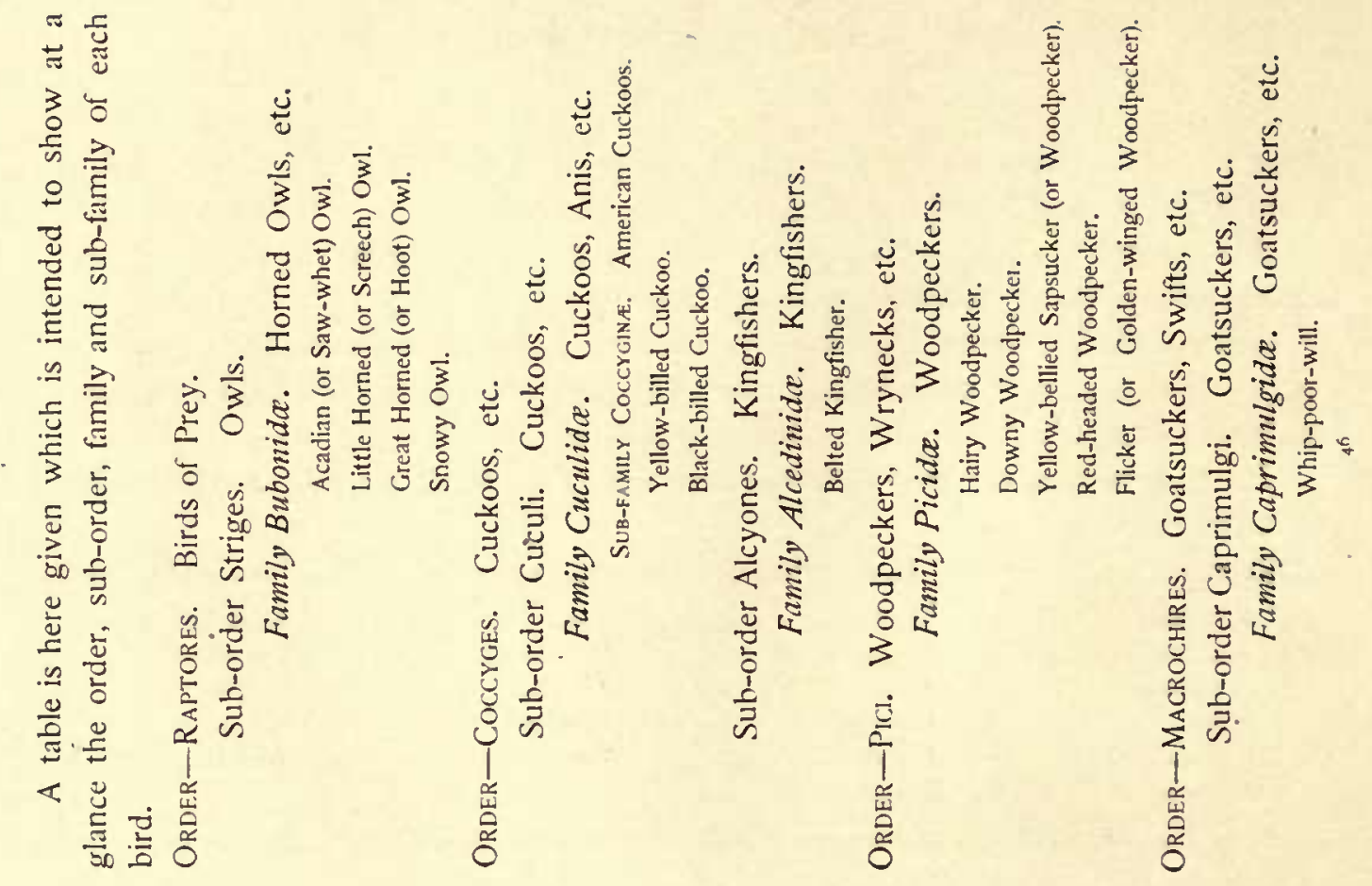




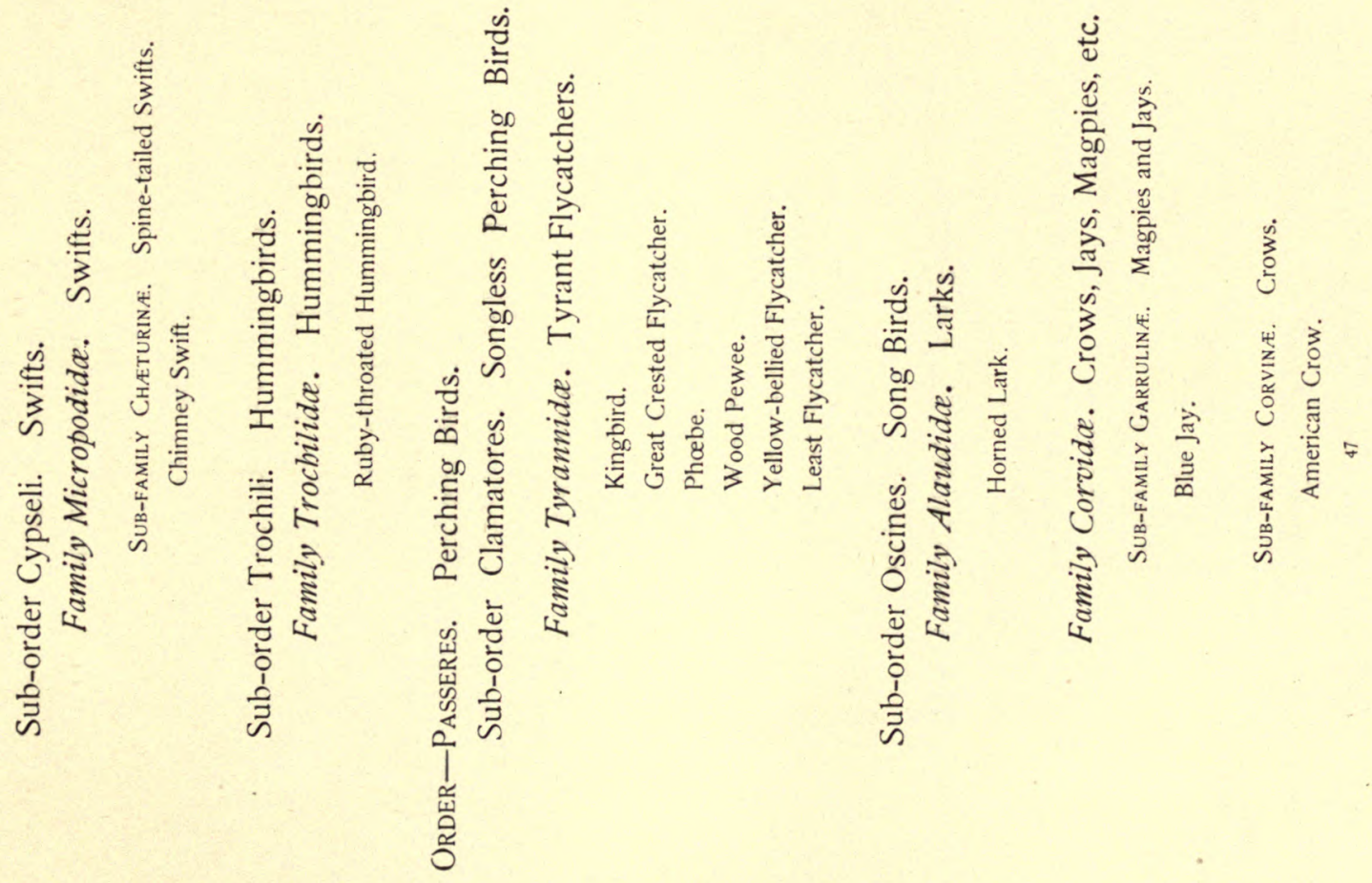




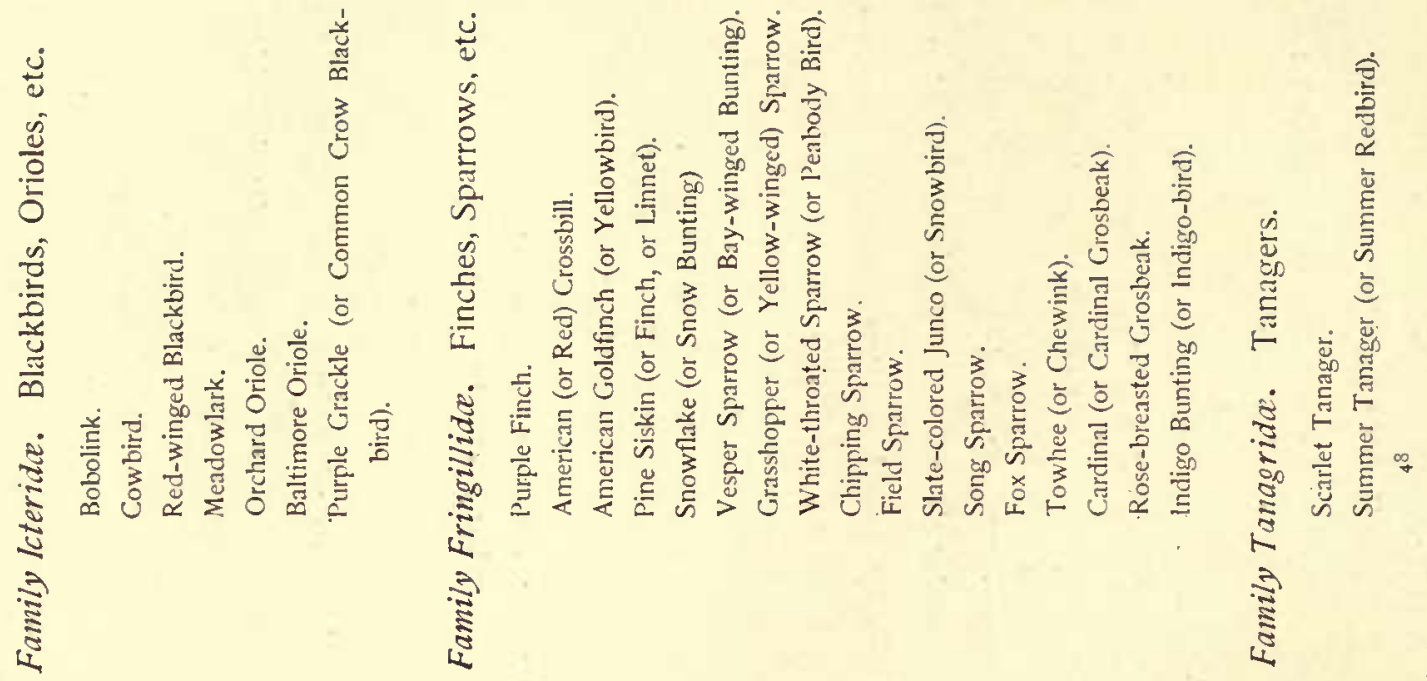




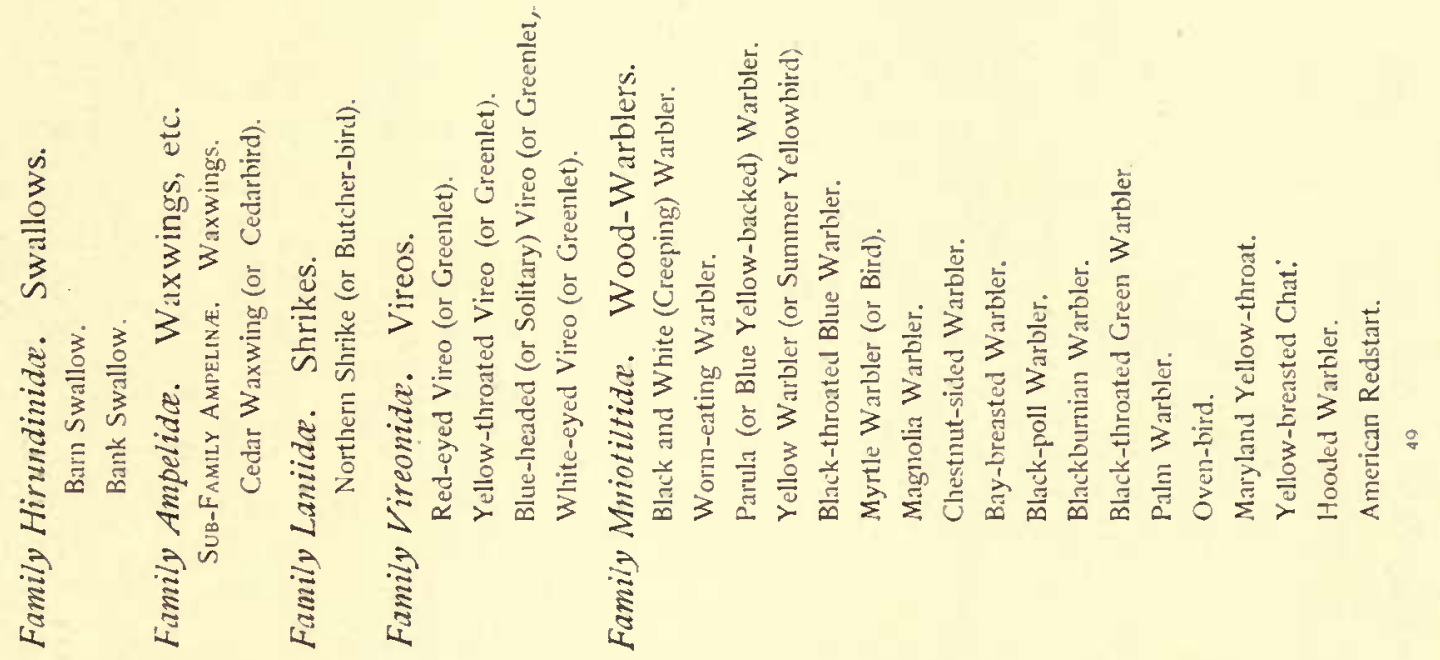




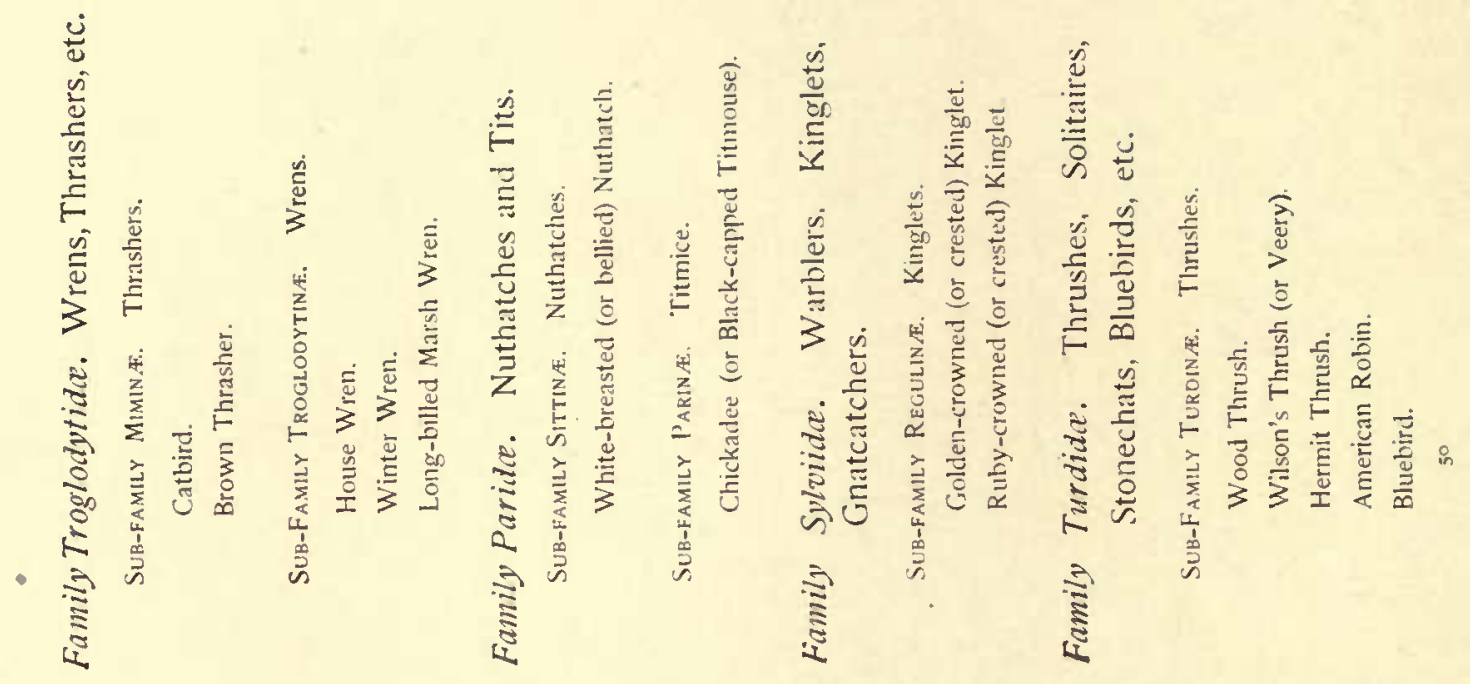




\section{Our Common Birds and How to Know Them}

The largest family of North American birds is the Fringillida, and comprises Finches, Buntings, Sparrows, Linnets, Crossbills, Grosbeaks, etc. The observer will meet numbers of these and will doubtless at first find it difficult to identify many of them. The next largest family that he will have to examine is the Mniotiltide or Wood-warblers, a family perhaps still more difficult of identification, since they are mostly small, shy birds, impatient of close inspection and songsters of small ability. Dr. Coues calculates that these two families constitute about one-fourth of the species inhabiting any one inland locality. Flycatchers and Vireos are also usually abundant and are likewise not the easiest of birds to identify. But, with few exceptions, and referring always to the males only, the birds of the remaining families can be easily learned. They present such notable features of plumage, song or habits that they need only to be seen or heard to make identification certain. 


\section{PLATES}

AND

DESCRIPTIVE TEXT 


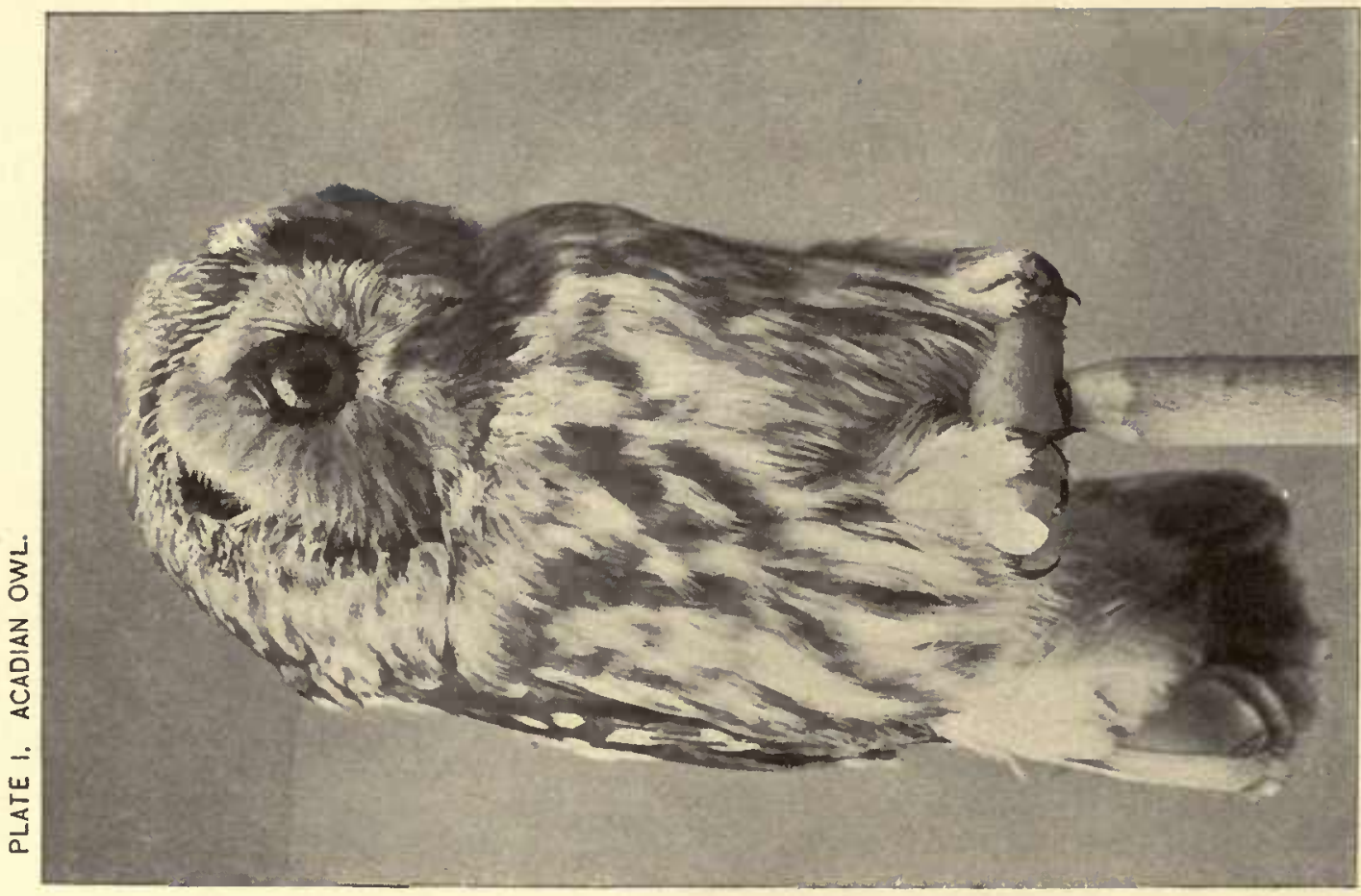




\section{PLATE I.-ACADIAN OWL. SAW-WHET OWL.}

Nyctala acadica.

Above reddish-brown spotted with white; beneath grayish-white splashed with brown; much white on throat and neck; tail somewhat barred; iris yellow ; bill and claws, dark. Length, 8 inches.

Resident.* The smallest of our Owls, and, though from its shyness not frequently seen, not an uncommon bird. It nests in hollow trees or stumps, or in holes in rocks. Audubon says: "The sound of its love-notes bears a great resemblance to the noise produced by filing the teeth of a large saw." It is this similarity which has gained the bird its common name Saw-whet.

* It is believed that no individual bird inhabits permanently, that is throughout the year, any one locality, but that all birds are migratory. Some species, as the American Goldfinch, the Chickadee and the Hairy, and Downy Woodpeckers, usually have representatives here at all seasons. But the individuals seen in Winter have spent the 


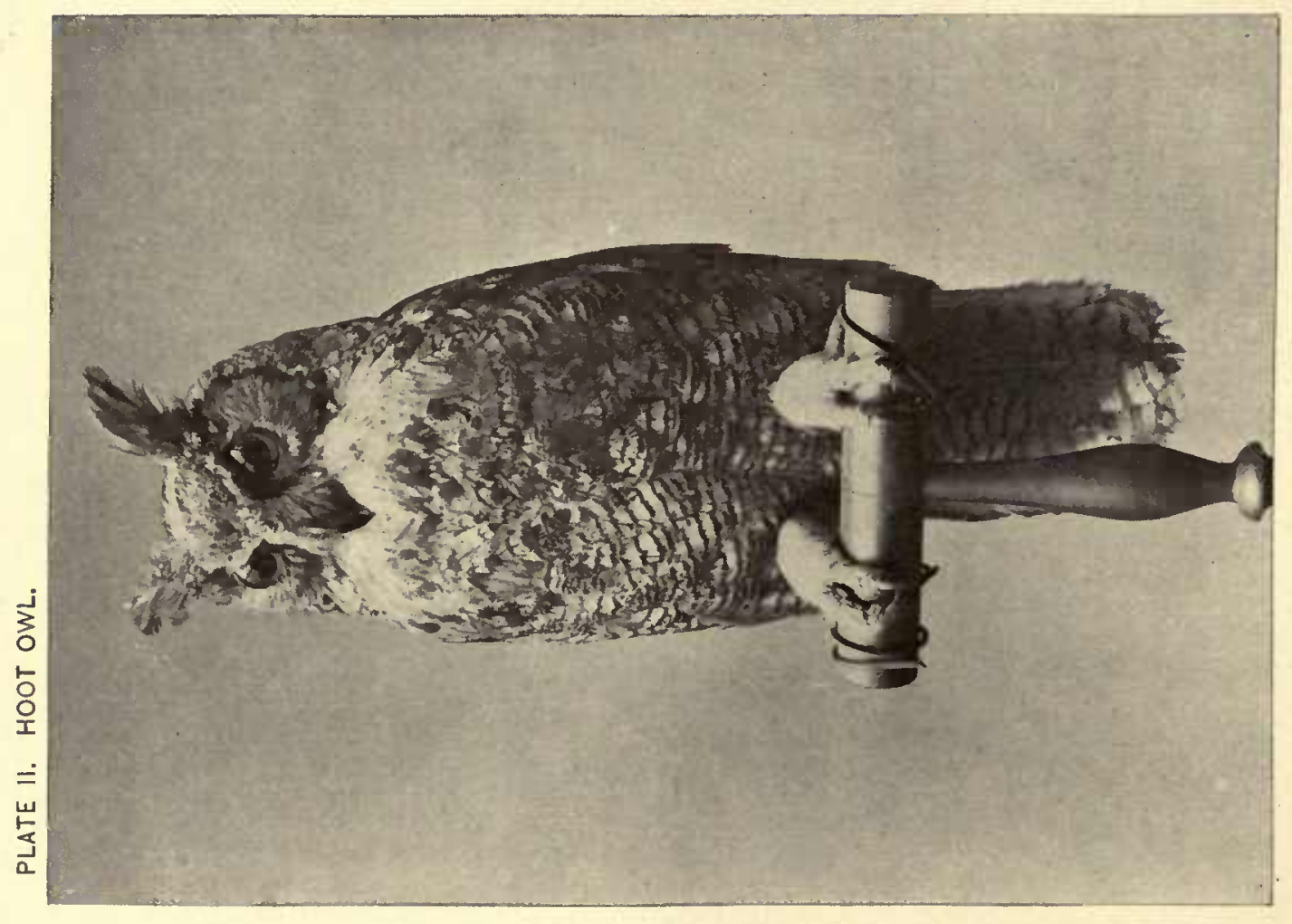




\section{PLATE $11 .-$ GREAT HORNED OWL. HOOT OWL.}

\section{Bubo virginianus.}

Mottled all over with brown, gray, tawny and black; a light collar about the throat; large ears tufted; iris yellow; bill and claws black. Length, 21.45 inches.

Resident. One of the largest of our Owls, and so fierce, that when slightly wounded he is i formidable antagonist.

Said to breed in February. Nests in trees. Though somewhat variable in color, the light collar is always present.

Sunmer farther north, those seen in Summer having gone southward. These, and other hirds of similar habits, are here classed RESIDENT.

Some of the Warblers visit us for a few weeks as they pass northward in the Spring, and southward in the Fall. Some birds, as the Snownlake, are seen here only in Winter. Others, as the Swallow, the House Wren and many more, come only in Summer. Birds with such habits are here classed MigRATORY. 


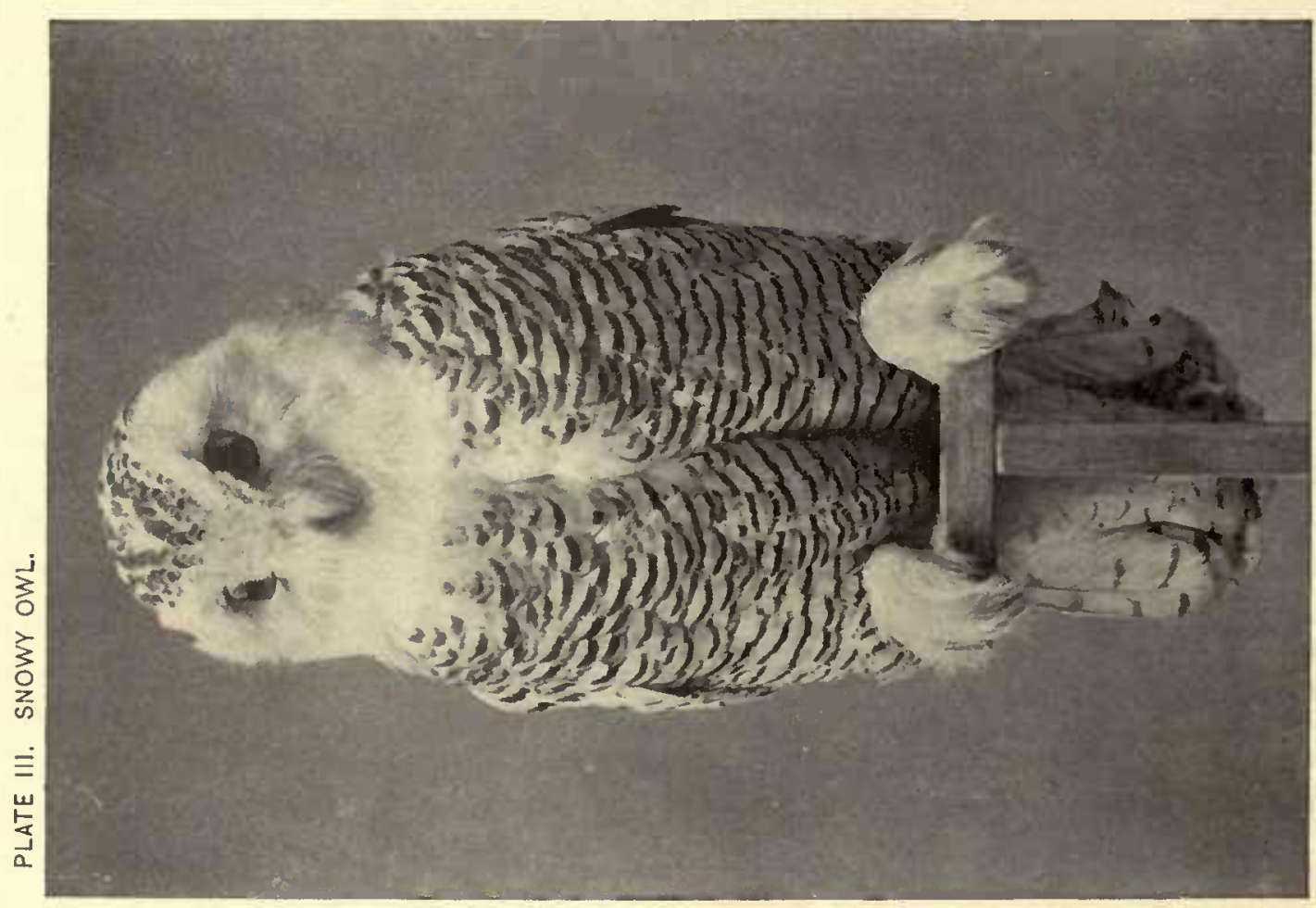




\section{LITTLE HORNED OWL. SCREECH OWL. RED OWL.}

\section{Megascops asio.}

Mottled with black, brown and gray; ears tufted; iris yellow : bill and claws horn color. Length, 9.40 inches.

Resident. Breeds in stumps, holes of trees or in buildings. The commonest $\mathrm{Ow}$ l we have, but so variable in color that the above slight description must not be regarded as universil. It is sometimes mottled, sometimes brown and sometimes red, "entirely independent," as Dr. Coues remarks, "of age, season or sex."

\section{PLATE 111.-SNOWY OWL.}

Nyctea nyctea.

White, spotted all over with brown, except on face, throat and legs,. which are immaculate; iris yellow; bill and claws dark. Length, 23.50 inches. 


\section{PLATE IV. BLACK.BILLED CUCKOO.}

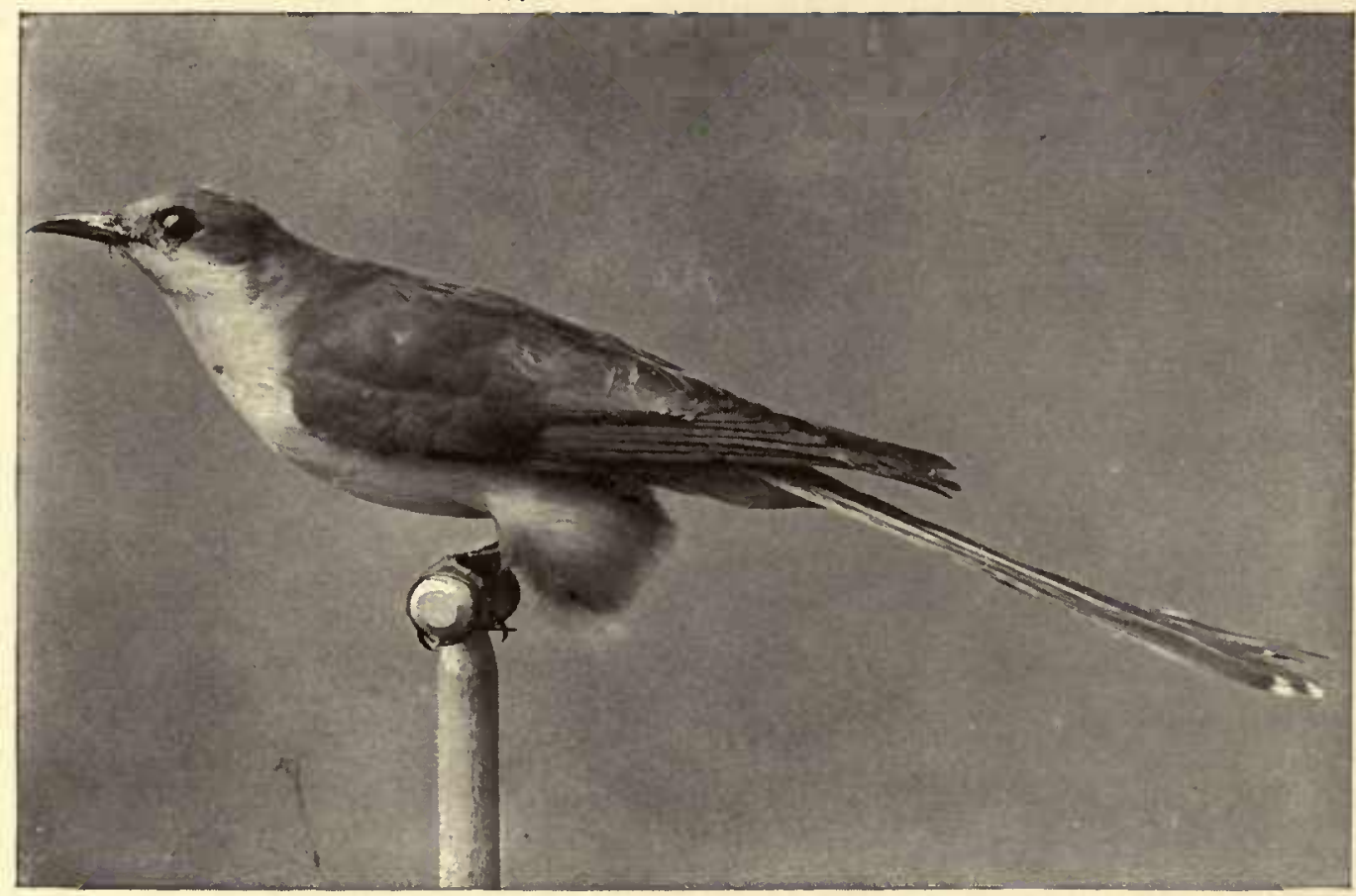


"This remarkable owl," says Dr. Coues, "conspicuous in size and color, abounds in the boreal regions of both hemispheres, whence it comes southward irregularly in Winter, sometimes raiding in large numbers. With us, it is of every Winter occurrence in the Northern and Middle States, sometimes even pushing its way to the Carolinas and Texas; there being no part of the United States where it may not appear at that season. It is far from being exclusively nocturnal, and hunts abroad in the day-time as readily as any hawk."

\section{PLATE IV.-BLACK-BILLED CUCKOO.}

Coccyzus erytbropbtbalmus.

Above olive-green; beneath white; a circle of red skin around the eye; bill black, long and arched; tail long and rounded. Length, 11.80 inches.

Migratory. Arrives early in May, leaves late in September. Nests in bushes. Call $k u k-k u k-k u k-k u k$, many times repeated, commencing rapidly, but with slower enunciation at the close. The sound does not in the least suggest the note of the European variety, neither does it resemble the common pronunciation of its name. It has a hoarse quality, 
however, which distinguishes it from the utterance of any other bird. He who once hears the note will at once feel sure of its identity.

Mr. Burroughs writes of the Cuckoo: "Nothwithstanding the disparity of size and color, the black-billed species has certain peculiarities that remind one of the passengerpigeon.

"His eye, with its red circle, the shape of his head, and his motions on alighting and taking flight, quickly suggest the resemblance; though in grace and speed, when on the wing, he is far inferior. His tail seems disproportionately long, like that of the red thrush (Brown Thrasher), and his flight among the trees is very still, contrasting strongly with the honest clatter of the robin or pigeon."

The Yellow-billed. Cuckoo (Coccyzus americanus) is a more southern bird, much less frequently seen here than the Black-billed, which it closely resembles. Its salient peculiarities are that it has no red around the eyes, its lower mandible is yellow, and it has large white blotches on the under side of its tail.

lts nest is very slightly constructed and is commonly placed in a tree. 


\section{PLATE V.-BELTED KINGFISHER.}

Ceryle alcyon.

Above ashy blue; a band of the same across the breast; remainder of underparts and a spot before the eye white; tail square, banded and spotted with white; head large, and splendidly crested; bill long, black; feet dark. Length, 13 inches.

Resident, except when driven southward by excessive cold, Note, a loud rattle. Nests in holes dug in a dry, sandy bank. Its haunts are brooks and river-banks, where it may be seen stationed upon some overhanging branch ready to plunge into the stream after its prey.

Watch it, and it will soon dart down into the water with a heavy splash, and then mount again to its perch, generally bearing a fish in its beak. The fish is beaten upon the limb until killed, or until the spines of its fins have been crushed, after which it is swallowed. a feat of seeming difficulty and little apparent enjoyment, and only accomplished after much gulping and stretching of neck, jerking of wings and contortion of body.

Now draw nearer, and the bird will take its flight, springing its rattle with angry in- 
PLATE V. BELTED KINGFISHER,

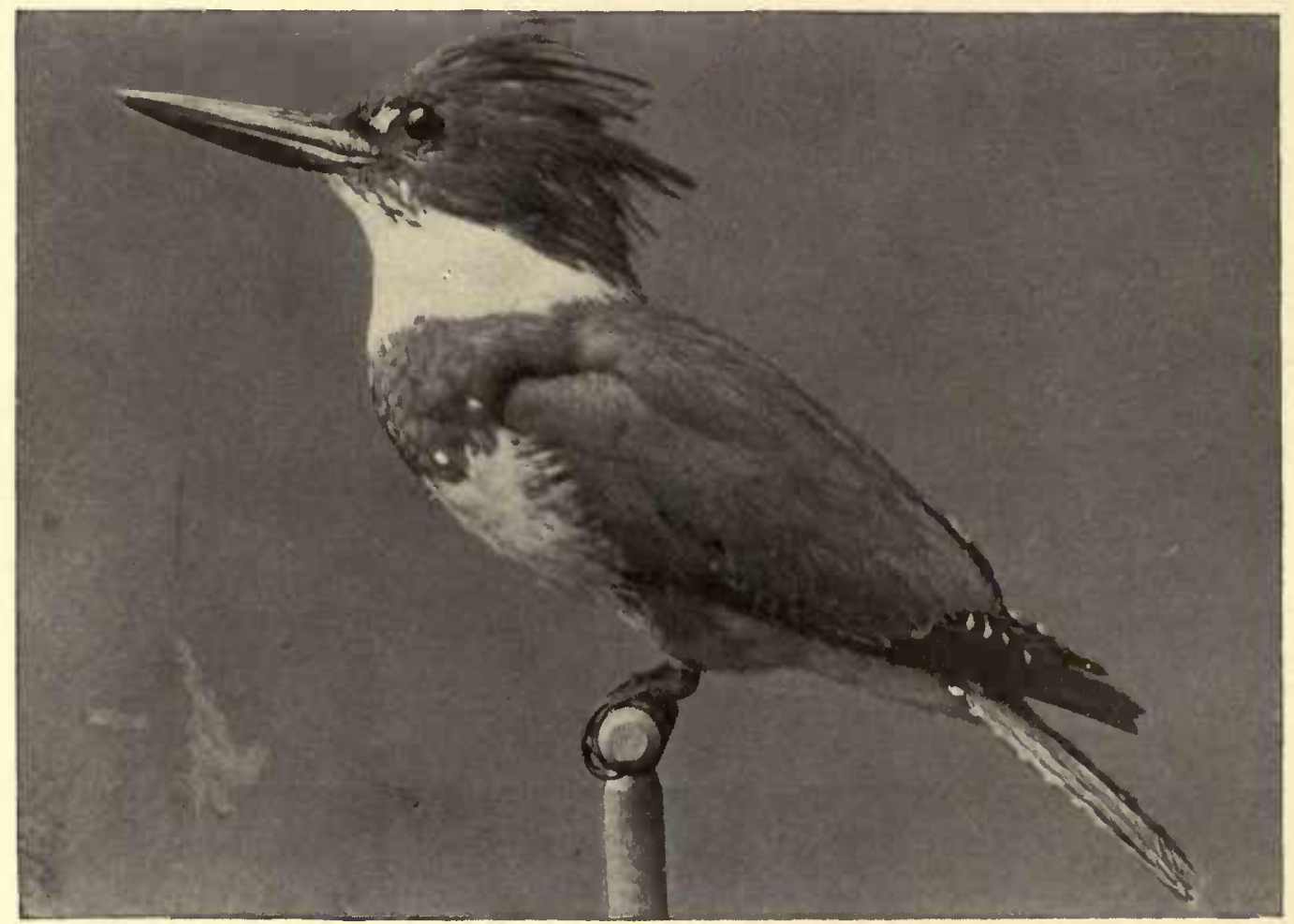


tonation as it goes, but alighting again at no great distance beyond, and always following the course of the stream.

Thus gently urged along, it will make many successive short flights before taking its final departure.

The phrase "halcyon days" is derived from a legend concerning this bird. The Halcyon (Kingfisher), was believed to build its nest upon the water, where, with its complement of eggs, it floated out to sea, the parent bird meanwhile brooding and exerting the occult power possessed by it of preventing storms or tempests during the period of incubation. The continuance of this elemental peace and quietude was called "halcyon days," and later, all times of tranquility, whether physical or moral, came to bear the same appellation. Another common, classical mention of the Kingfisher, and more than once referred to by Shakespeare, indicates that the stuffed skin of this bird, suspended by a thread, was used by the ancients as a weather-vane. One can readily perceive that the skin of a bird might be so adjusted that the beak must always point to the source of the wind. That the Kingfisher alone was selected for this purpose is probably due to its handsome appearance, and to the ease with which it would be possible to discern the position of its beak and magnificent head. 
PLATE VI. HAIRY WOODPECKER.

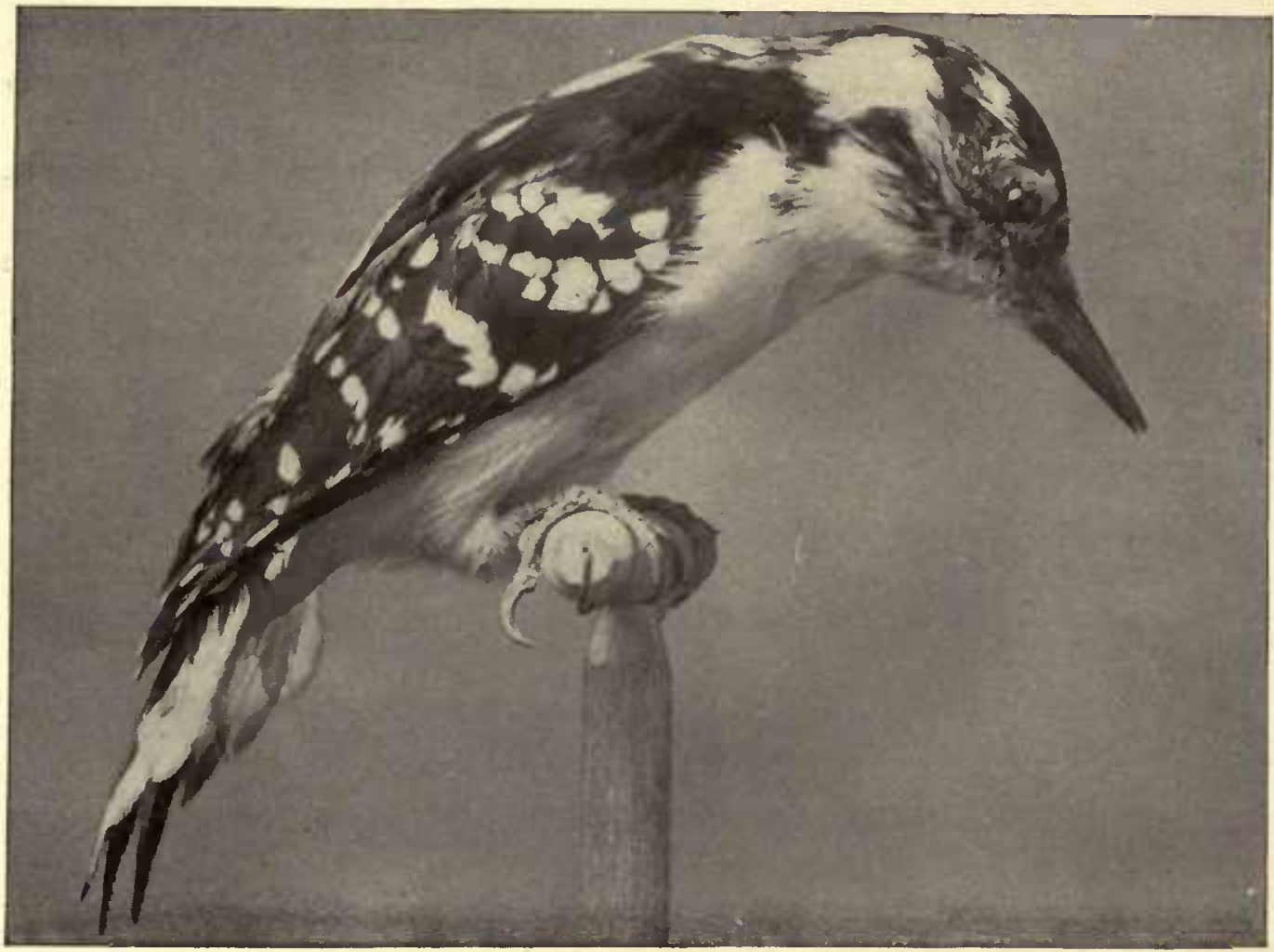




\section{PLATE VI. - HAIRY WOODPECKER.}

Dryobates villosus.

Head black, with a white streak under and one over the eye, and with a scarlet band on the crown; back black, with a white stripe down the centre- "the feathers composing this stripe are loose and unwebbed, resembling hairs;" beneath white; wings black, much spotted with white; tail black, the two outer pairs of feathers white; bill and legs black. Length, 9.40 inches.

Resident. Flight undulatory. Nests in a hole which it has dug in a tree situated commonly in the woods. Its call is a harsh scream.

Closely resembling the Hairy Woodpecker in appearance and habits, but smaller, is the Downy WOODPECKer (Dryobates pubescens).

A peculiarity of this bird, sufficient to prevent confounding it with the preceding, is, that its white outer tail-feathers are barred with black. 


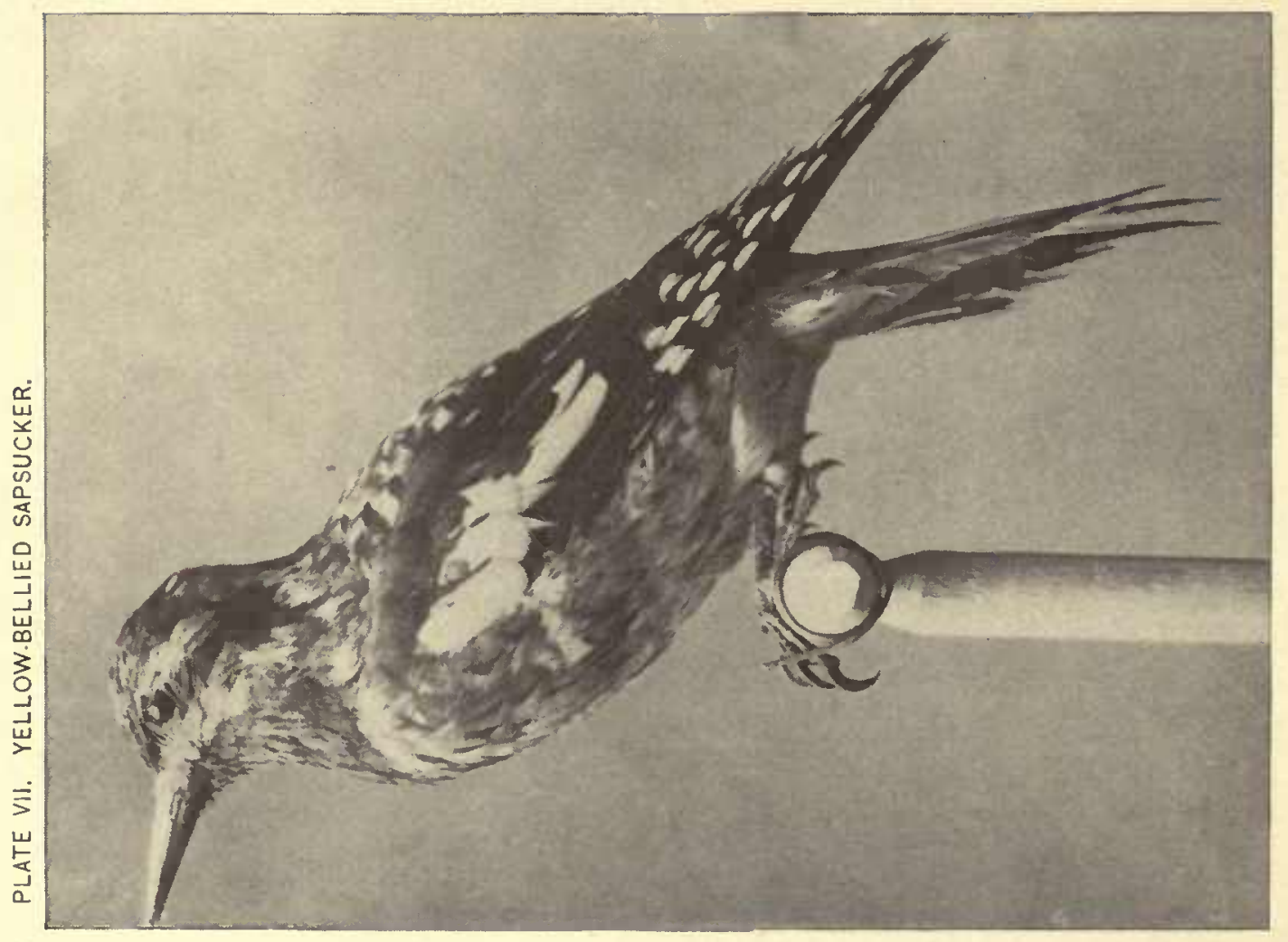




\section{PLATE VII.-YELLOW-BELLIED WOODPECKER. YELLOW- BELLIED SAPSUCKER.}

Sphyrapicus varius.

Crown crimson, inclosed by a half-moon of black, and that similarly bordered for most of its circumference by a band of yellowish-white ; back mottled with black and yellowish-white; sides of head yellowishwhite, cut by a black streak which passes through the eye; throat and upper-breast black, with a large crimson patch on chin; remainder of under-parts yellowish-white, marked on the sides with brown; wings black, much barred, spotted and tipped with white; tail black, with a white streak down the centre, wedge-shaped, the feathers pointed and some of them bordered with white; bill and feet dark. Length, 8.55 inches.

The Yellow-bellied Sapsucker is represented here at all times of the year ; but only during Spring and Fall is it present in any considerable force.

Dr. Coues writes: "Birds of this remarkable genus feed much upon fruits as well als 


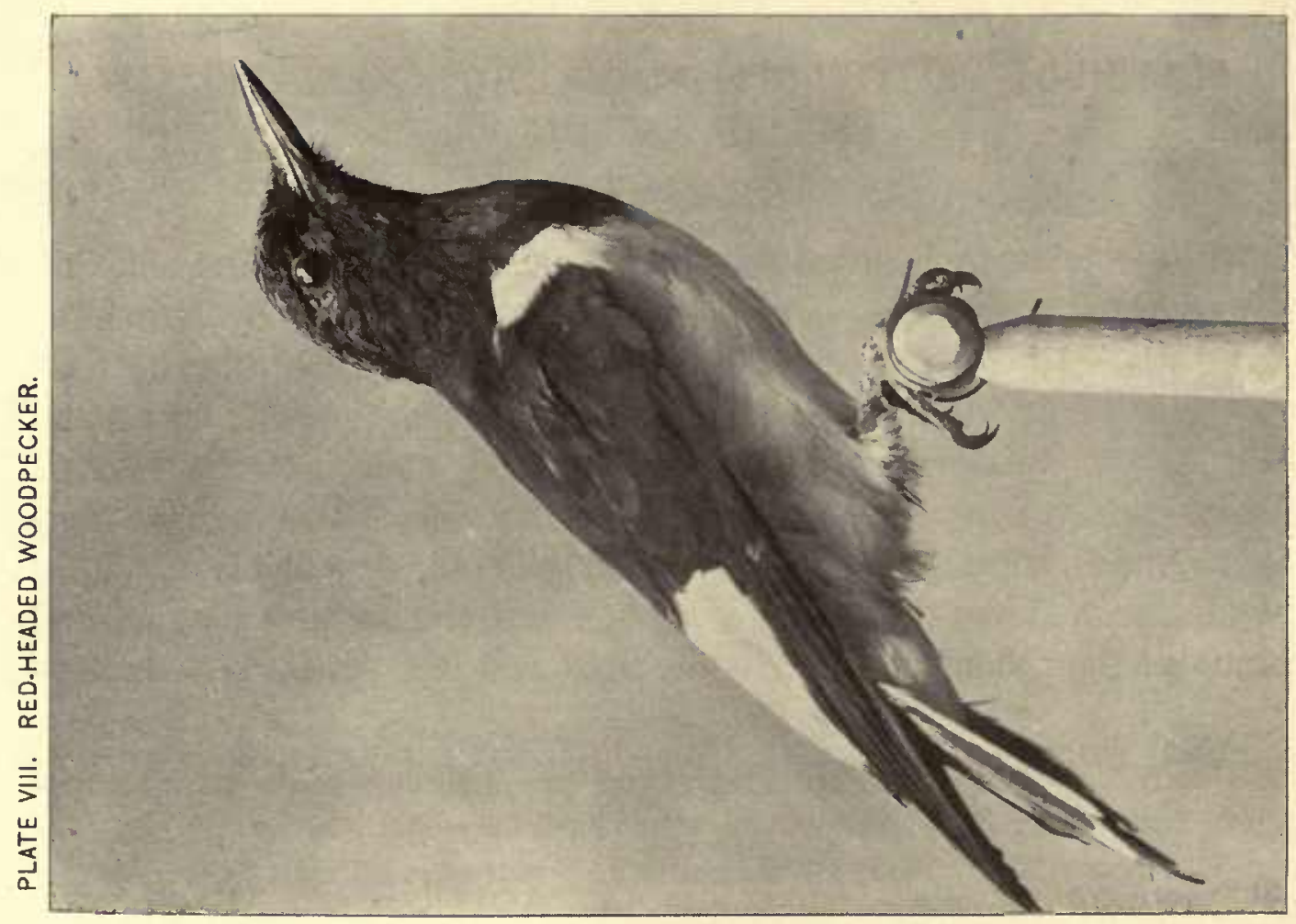


insects, and also upon soft, inner bark; they injure fruit-trees by stripping off the bark, sometimes in large areas, insteald of simply boring holes.

"Of the several small species (of Woodpeckers) commonly called 'Sapsuckers,' they alone deserve the name. In declaring walr against Woodpeckers, the agriculturist will do well to discriminate between this somewhat injurious and the highly beneficial species."

Its nest is in a hole which it has dug, usually in a dead forest-tree.

It has a number of harsh cries.

\section{PLATE VIII.-RED-HEADED WOODPECKER.}

\section{Melanerpes erytbrocephalus.}

Head and neck all round, crimson; back black to rump, which is white; lower breast and belly white ; wings black, with a broad white band; tail black, somewhat tipped with white, rounded, and feathers pointed; bill and feet dark. Length, 9.75 inches.

Migratory. Seen here most frequently in the Spring and Fall. Digs a hole for a nest in al tree in wood or orchard. Its note is high-pitched and resembles that of a tree-frog.

A paragraph in the columns of the New York Tribune, in the Fall of 1890 , stated that a bird of this species fluttered one night against a window of the editorial room, doubtless 


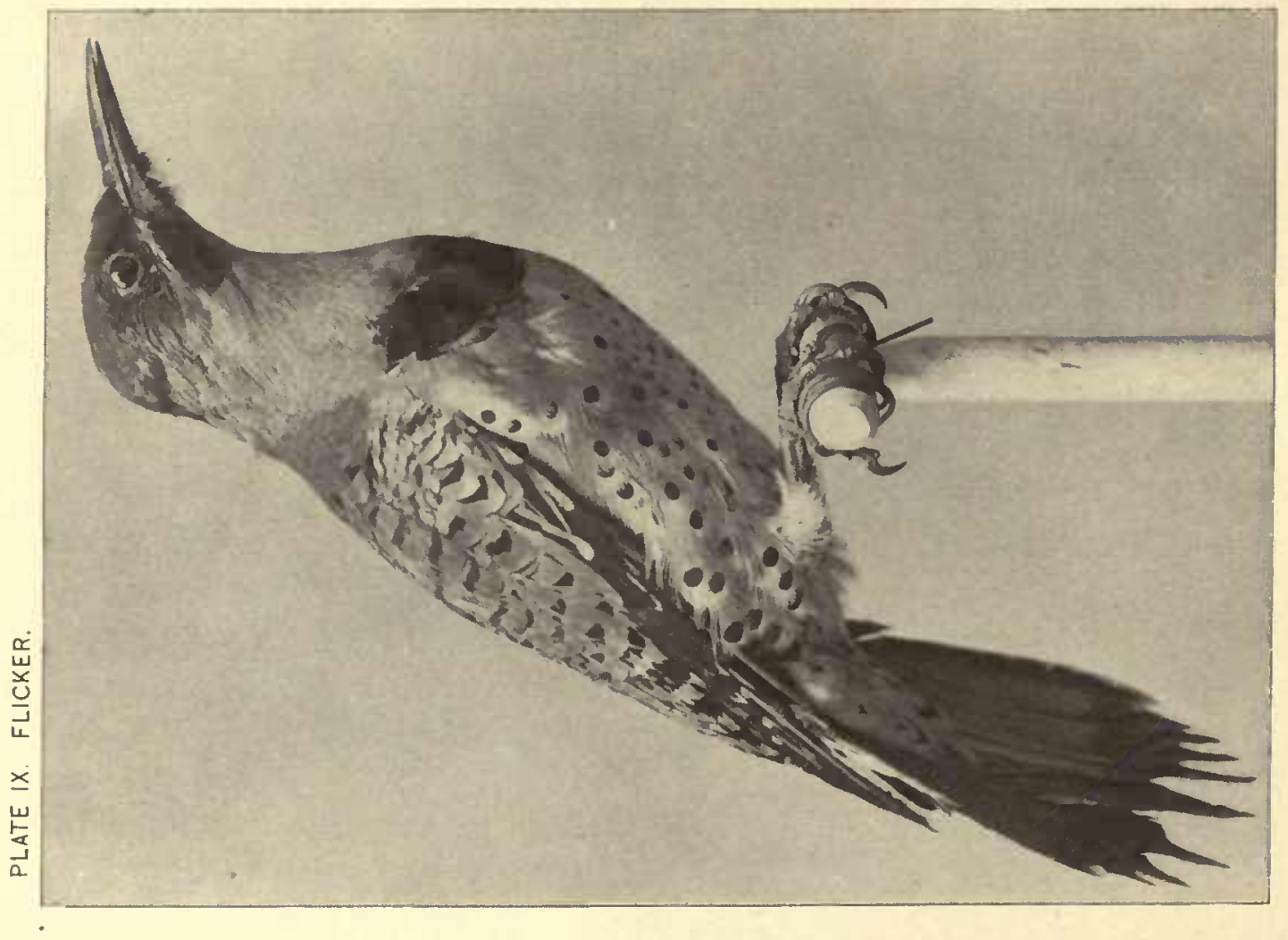


attracted and confused by the lights. The bird was admitted, allowed to rest, and then speeded on its way.

The writer was walking one Autumn in the City Hall Park of New York City, and observed a number of people earnestly regarding some object high up on the trunk of a neighboring tree. He asked a boot-black what they were all looking at, and was told, "A Woodchuck is up in that 'ere tree." Curious to witness a Woodchuck in so unusual a situation, the writer joined the concourse of gazers, and soon perceived a fine Red-headed Woodpecker clamber into sight from the further side of the tree-trunk, drumming assiduously and wholly unconscious of the excitement and interest he was provoking. Thinking it a good opportunity to bestow a bit of onithological knowledge, the writer informed his boot-black friend that the bird was a Woodpecker. "O yes," wals the rejoinder, "we calls 'em Woodchucks."

\section{PLATE IX.-FLICKER. GOLDEN-WINGED WOODPECKER. CLAPE. HIGH-HOLE.}

Colaptes auratus.

Sides of head, throat and breast lilac-brown, with black patches on cheeks and a large black half-moon on breast; back brown barred with 
PLATE X. WHIP-POOR-WILL.

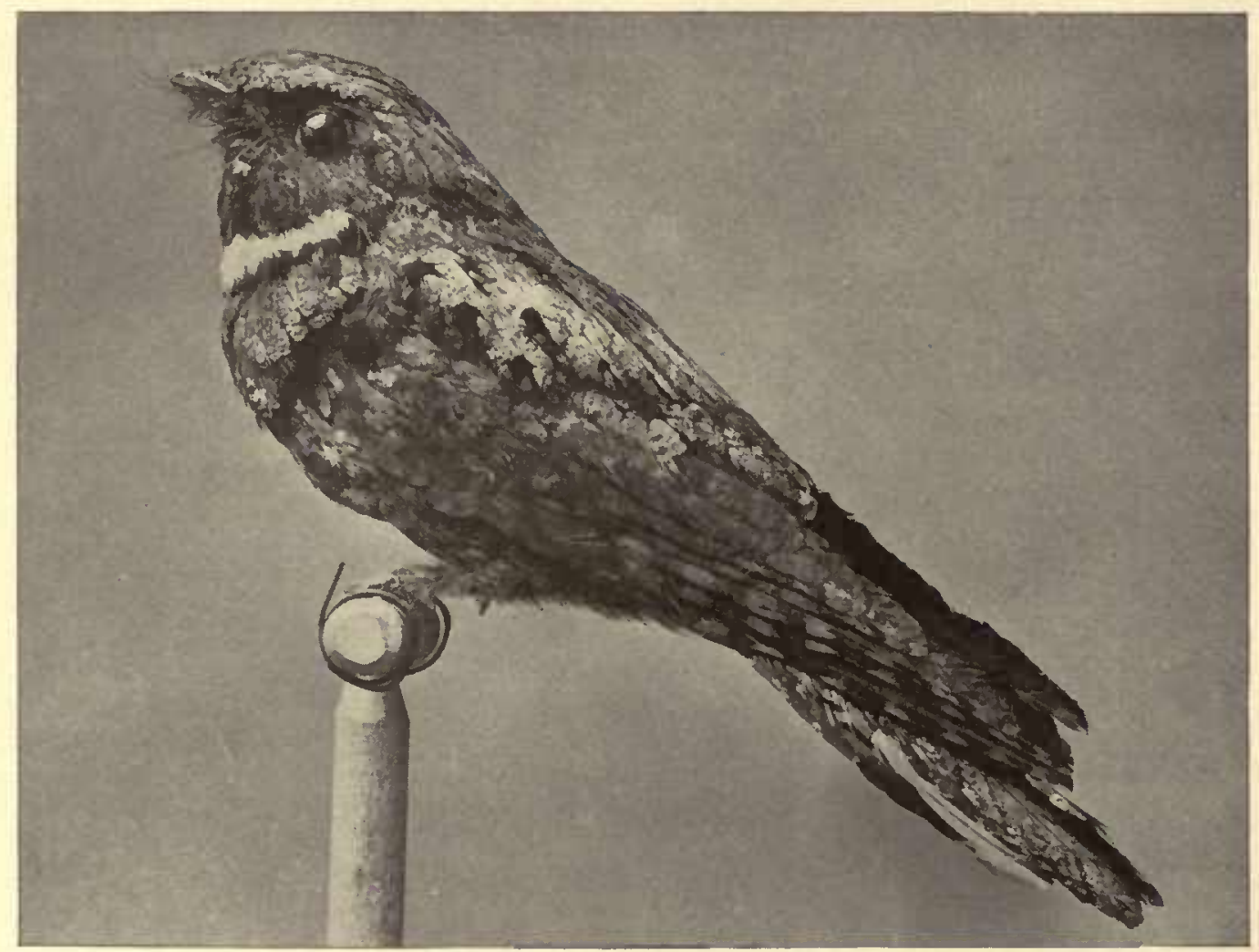


black; belly ashy, with many black spots; tail black above, golden beneath, rounded, the feathers pointed; lining of wings golden; rump white; scarlet crescent on nape; bill and feet dark. Length, 12.60 inches.

A resident species; the majority of them, however, coming in March and leaving by November. No bird has attracted more universal attention and interest than this one, a fact due, perhaps, no less to its size than to its great beauty and admirable proportions. As might be expected, it bears many local names; according to one aluthority, thirty-six. Its nest is built in a hole, dug, often in solid wood, high up in a tree; hence one of its commonest popular names, High-hole. Audubon writes, "Its note is merriment itself, as it imitates a prolonged and jovial laugh, heard at a considerable distance."

The black crescent on the breast is very prominent, and is clearly discernible when the bird is at rest, and the white rump is equally conspicuous during flight. The observer will find no difficulty in identifying this handsome species on sight.

\section{PLATE X.-WHIP-POOR-WILL.}

Antrostomus vociferus.

Mottled all over with reddish-brown, gray-black and soiled white; a white collar on neck; many bristles around the month; tail 


\section{PLATE XI. CHIMNEY SWIFT.}

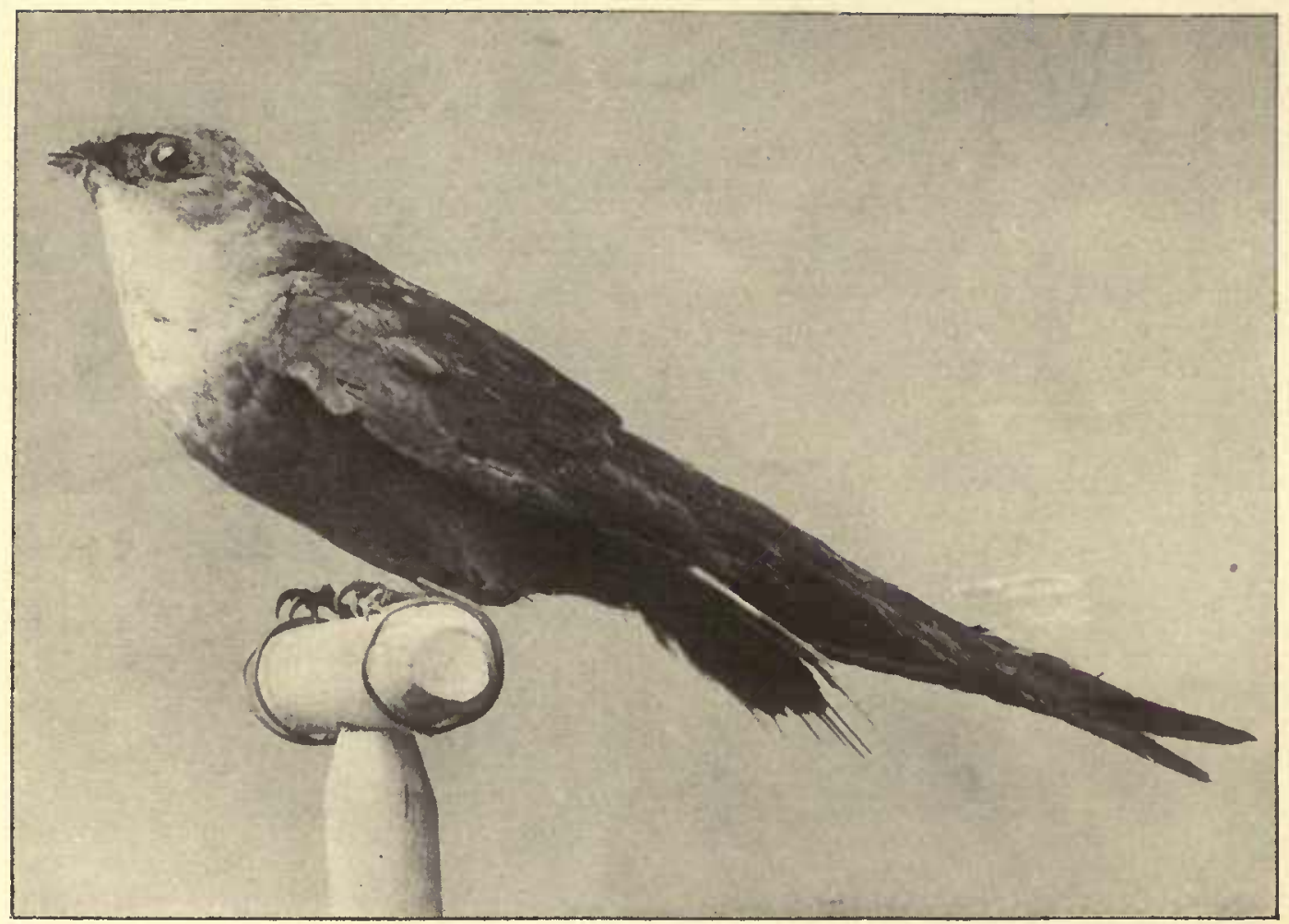


rounded and with patches of white on its under side. Length, 9.75 inches.

Migratory. Arrives early in May, leaves about the middle of September. Builds no nest, but lays its eggs on the ground or upon a stump. It is a nocturnal bird, lying closely in cover by day, and consequently not often seen ; at night, however, its call, clearly suggesting its common name, is frequently heard, a mournful, but not disagreeable, sound.

In general appearance the Whip-poor-will resembles the Night Hawk.

\section{PLATE XI.-CHIMNEY SWIFT.}

\section{Chatura pelagica.}

Sooty brown all over except the throat, which is light gray; eyes surrounded by a black skin; wings long, extending when folded beyond the tail ; tail short, spiny, square. Length, 5.40 inches.

Migratory. Arrives here about April 30 , and leaves late in September. Although the Chimney Swift superficially resembles the Swallow, it, in fact, has no real affinity with that bird, and the common practice of naming it a Swallow is an error. Its closest affinity is with the Hummingbird, which is its only superior in the art of flying. 
It inhabits chimneys or hollow trees, in which it builds nests of twigs glued together with its own saliva.

Its note is a swallow-like twitter, and it is equally voluble whether upon the wing or in its nest.

Seemingly rejoicing in its marvelous power of flight, it is never seen to alight except in chimneys, but it feeds its young, captures its insect prey, and even breaks twigs from trees for nest construction while flying.

\section{RUBY-THROATED HUMMINGBIRD.}

Trochilus colubris.

Above bright metallic green; beneath light gray; sides of body greenish; throat ruby-red; wings and tail dusky violet, the latter deeply forked; bill straight, long and dilated at the tip. Length, 3.75 inches.

Migratory. Arrives early in May, leaves in September. Its nest, which is a tiny affair, is usually placed on the upper side of a limb; it is made of lichens and is lined with vegetable down. 
The humming noise, which has occasioned its populat name, is produced by the air set in vibration by the extraordinarily rapid beats of its wings when it poises over the flower from which it extracts both honey and the insects which, like itself, are fond of that sweet substance, or perhaps are entrapped in its viscous grasp. Its only utterance is a sharp chirp or squeak.

No bird is so easily or quickly tamed as this, or so difficult to maintain alive when in captivity. A lady friend of the writer once found one on her porch overcome by the coldness of an unseasonable Summer day. She took it to her room and revived it by the warmth of her hands, and soon had the satisfaction of seeing it flitting about with apparent cheerfulness, hovering over some potted plants or alighting on her hand or head with charming confidence. The bird was detained for several weeks, fed meanwhile on sweetened water presented to it by means of a medicine dropper, into the tube of which it thrust its long bill, poising itself in the air for the operation.

One fine, bright day it darted out through an opened window and was seen no more. 
PLATE KII. KINGBIRD.

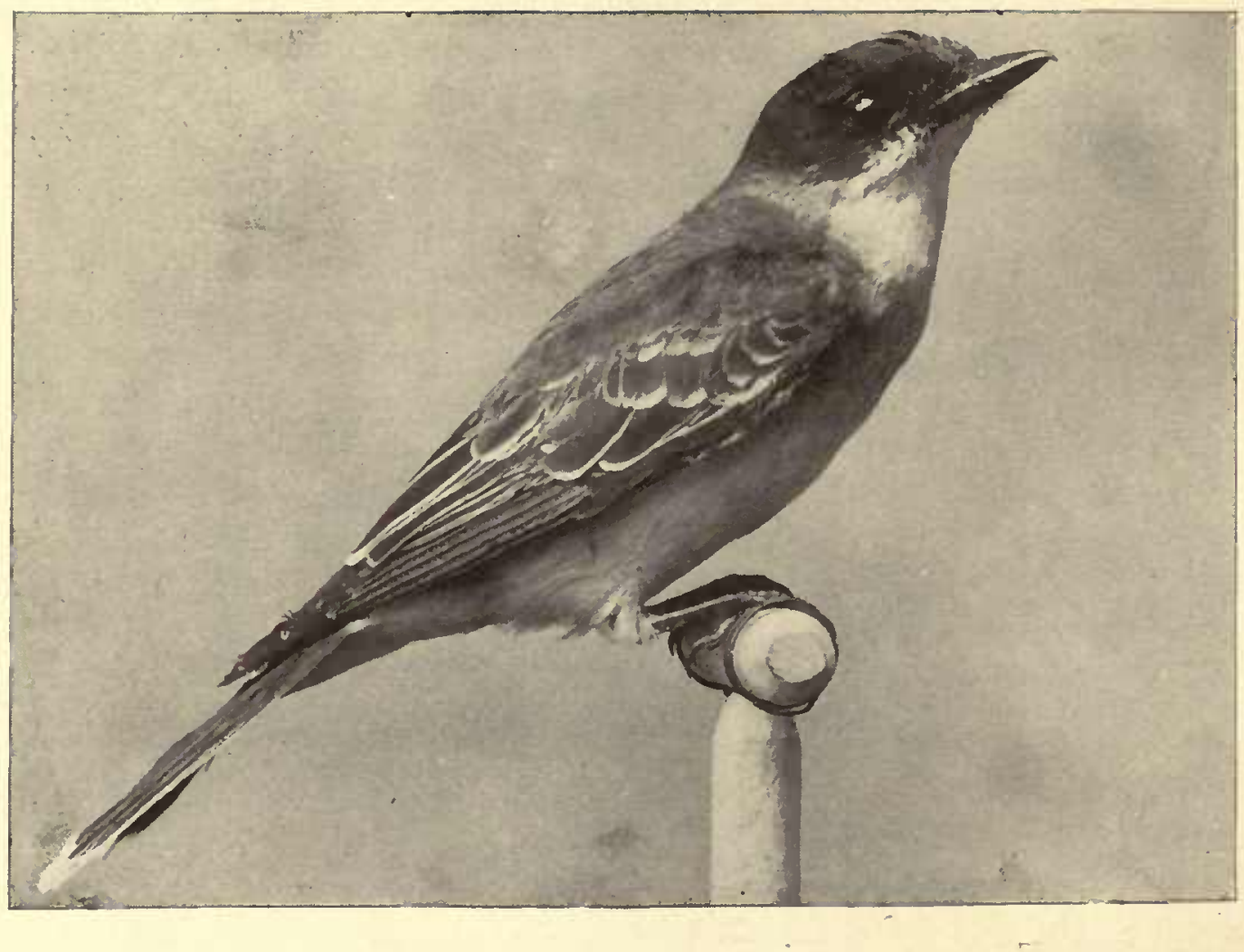




\section{PLATE XII.-KINGBIRD. BEE-MARTIN.}

\section{Tyrannus tyrannus.}

Above dark ash; beneath white shaded with light ash; head black, with an erectile crest in which is a spot of red; tail black, square and with a terminal white band; wing-feathers much edged with white; bill and feet black. Length, 8.50 inches.

Migratory. Arrives early in May, leaves early in September. It is brave and pugnacious, bullying small birds and attacking large ones.

Against the Crow particularly it seems to bear special enmity, and it charges this "dusky marauder" on sight with equal fury and pertinacity. In such an encounter it would be natural to suppose that the Crow's many times greater size would be sure to give it the advantage. This, however, is not the case. The Crow does not attempt even to defend itself, much less to retaliate, but flies stolidly on, seeking safety only in flight.

The honey-bee affords a most highly-prized tidbit to the Kingbird, and the gratification of the bird's taste has earned for it the name, Bee-martin. A swarm of bees consists of so many individuals that the disappearance of an occasional worker is no great loss to the insect community. But when it happens that the queen bee, out on her single wedding 

flight, is snapped up by a discriminating Kingbird, then a calamity indeed has befallen the swarm which can only be remedied by manufacturing another queen, an operation involving both time and trouble. Fortunately the Kingbird atones for its lapses into bee-diet by devouring great quantities of harmful insects.

\section{PLATE XIII.-GREAT CRESTED FLYCATCHER.}

Myiarcbus crinitus.

Above olive-green, darkest on the head, which is crested; throat and breast ash; belly yellow; wings and tail reddish-brown, the former with a pale, transverse bar, and the latter long and nearly even; bill and feet dark. Length, 9 inches.

Migratory. Arrives about May 10, leaves about September 25. Builds its nest in trees and is said to use the cast off skins of snakes in its construction. This constant use of snake-skins is commonly supposed to be in accordance with al desire to frighten off marauders by the display of what they shall haply take to be the live presence of their dreaded common enemy. A recent writer states that in all the nests of the Great Crested Flycatcher found by him, only once was the snake-skin absent, and, in this 
PLATE XIV. PHCEBE.

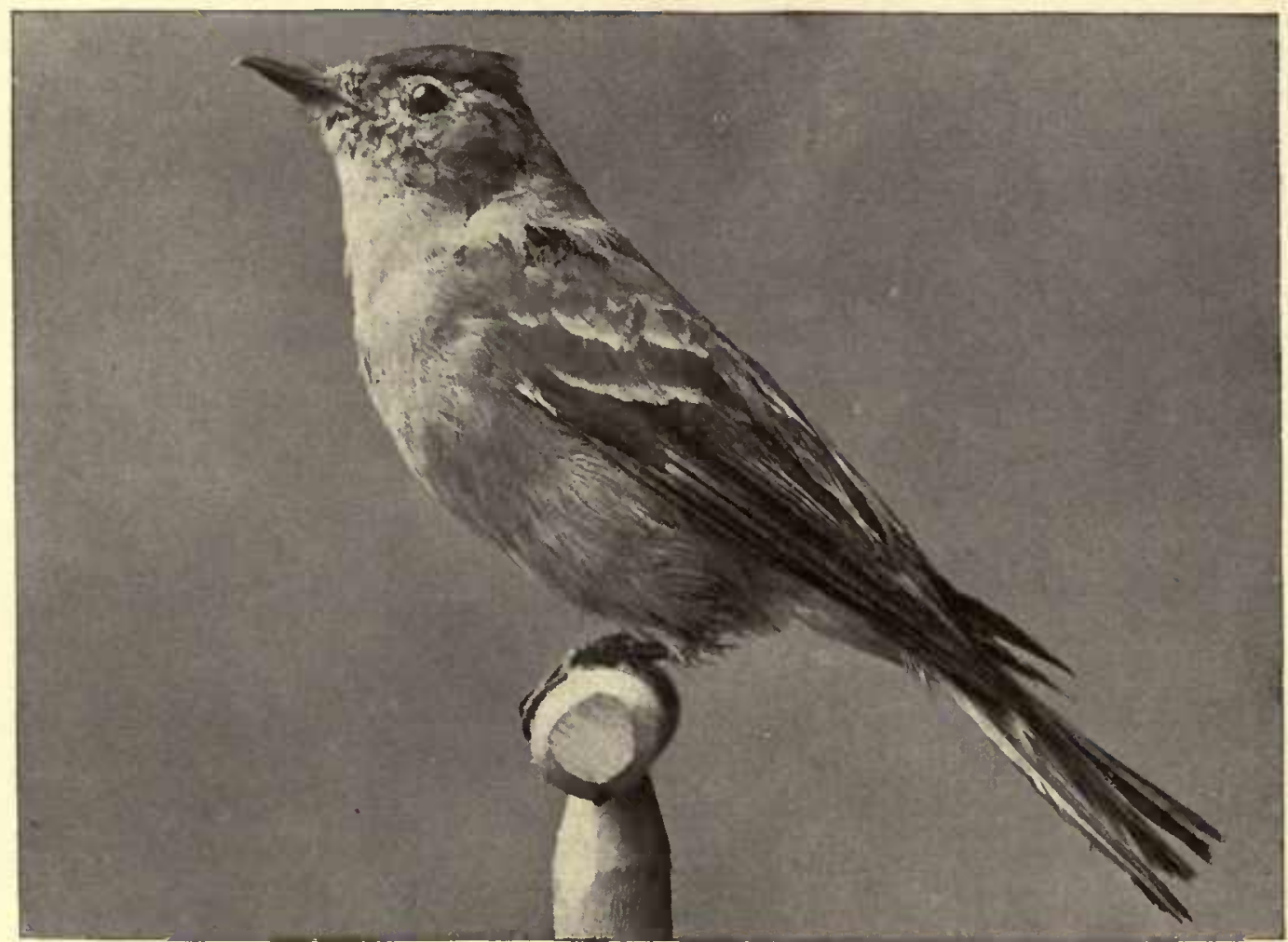


instance, upon his second visit, he found a skin ostentatiously displayed, whence he conjectured that his first visit had alarmed the birds, and that they had subsequently provided tnemselves with the talisman and put it in place with a view to avert, if not a recurrence of the intrusion, at least any danger as a result of it. The note of the bird is harsh and unmusical.

\section{PLATE XIV.-PHCEBE.}

Sayornis phobe.

Head dark brown, with a slight erectile crest; back and sides of body dull olive-brown; underparts soiled white with yellow tinges; wings and tail dusky, their feathers somewhat edged with lighter; bill and feet black. Length, 7 inches.

Migratory. Arrives late in March, leaves late in October. It commonly builds its nest under the eaves of buildings, or under a ledge of rock.

Closely resembling the Phœbe in note, habits and appearance, is the WOOD PEWEE, (Contopus virens). Both the Phoebe and the Wood Pewee are flycatchers, and seize their prey upon the wing. Both give utterance to a drawling, mournful note quite similar in sound; that of the Phœbe being slightly the more abrupt of the two, as pee-wit rather than pee-ee-wee-ee. 
PLATE XV. YELLOW.BELLIED FLYCATCHER.

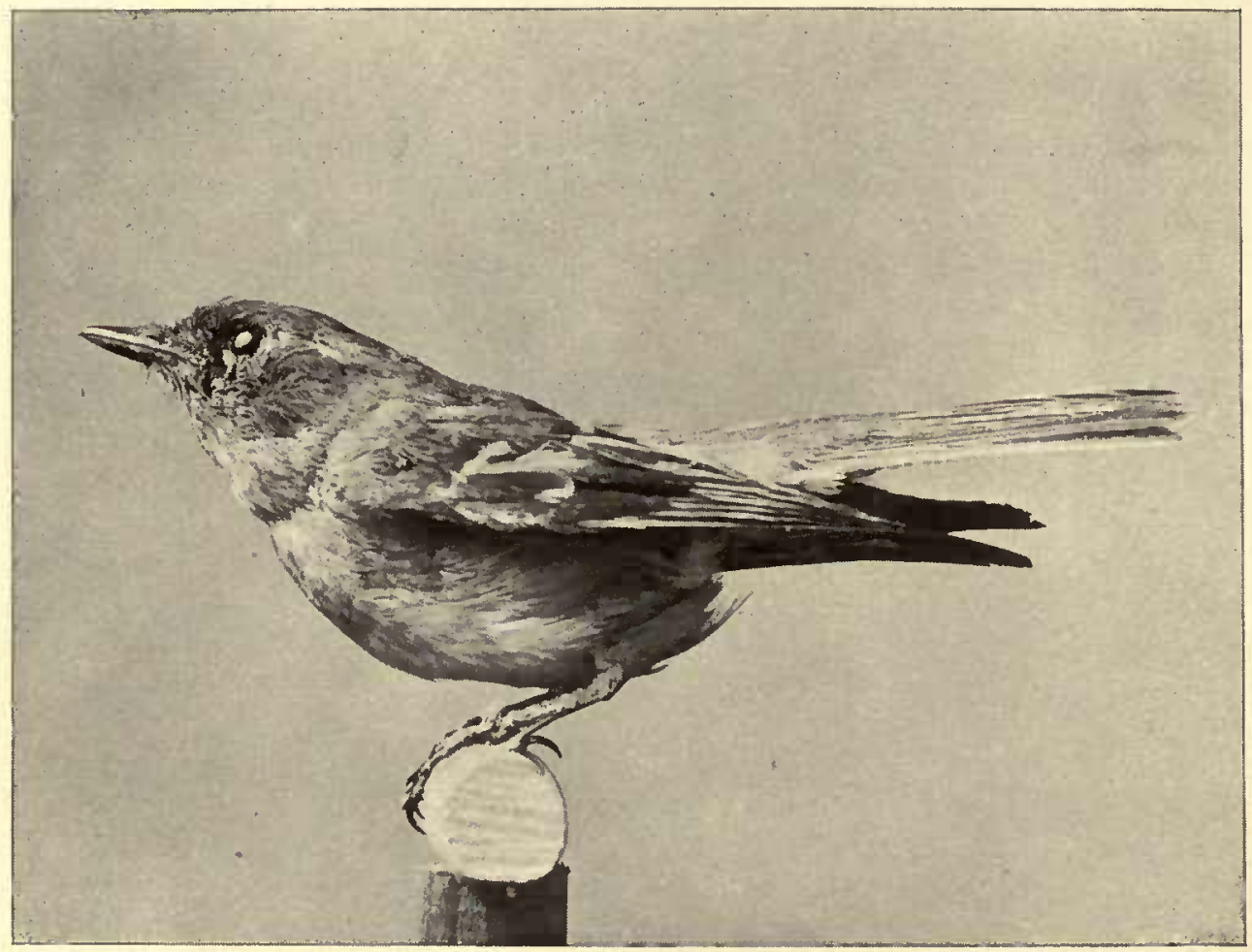


The Phœbe also is the larger bird, and both of its mandibles are black, while the lower mandible of the Pewee is lighter than its upper one. The Pewee nests in trees.

A characteristic habit common to both of these birds is that of drooping wings and tail as they perch, presenting a languid appearance quite in keeping with the lugubrious tone of their note. Let an unwary fly approach, however, and this lassitude quickly vanishes. A lightning dart with unerring aim, a snap of the beak audible at a distance of several yards; a twist, almost a somersault in the air, is made, the bird regains his station and resumes his despondent attitude, and there is one less insect abroad.

\section{PLATE XV.-YELLOW-BELLIED FLYCATCHER.}

\section{Empidonax flaviventris.}

Head and body, above olive-green; beneath greenish-yellow, except on the belly, where the yellow is pure; a yellowish ring encircles the eye; wings brown with yellowish bands; tail brown, square; bill broad, the upper mandible dark brown, the lower one pale. Length, 5.60 inches.

Migratory. This Flycatcher does not nest here. It is rather abundant, however, when on its migrations, and may be seen during the last three weeks of May; and, again, 


\section{PLATE XVI. LEAST FLYCATCHER.}

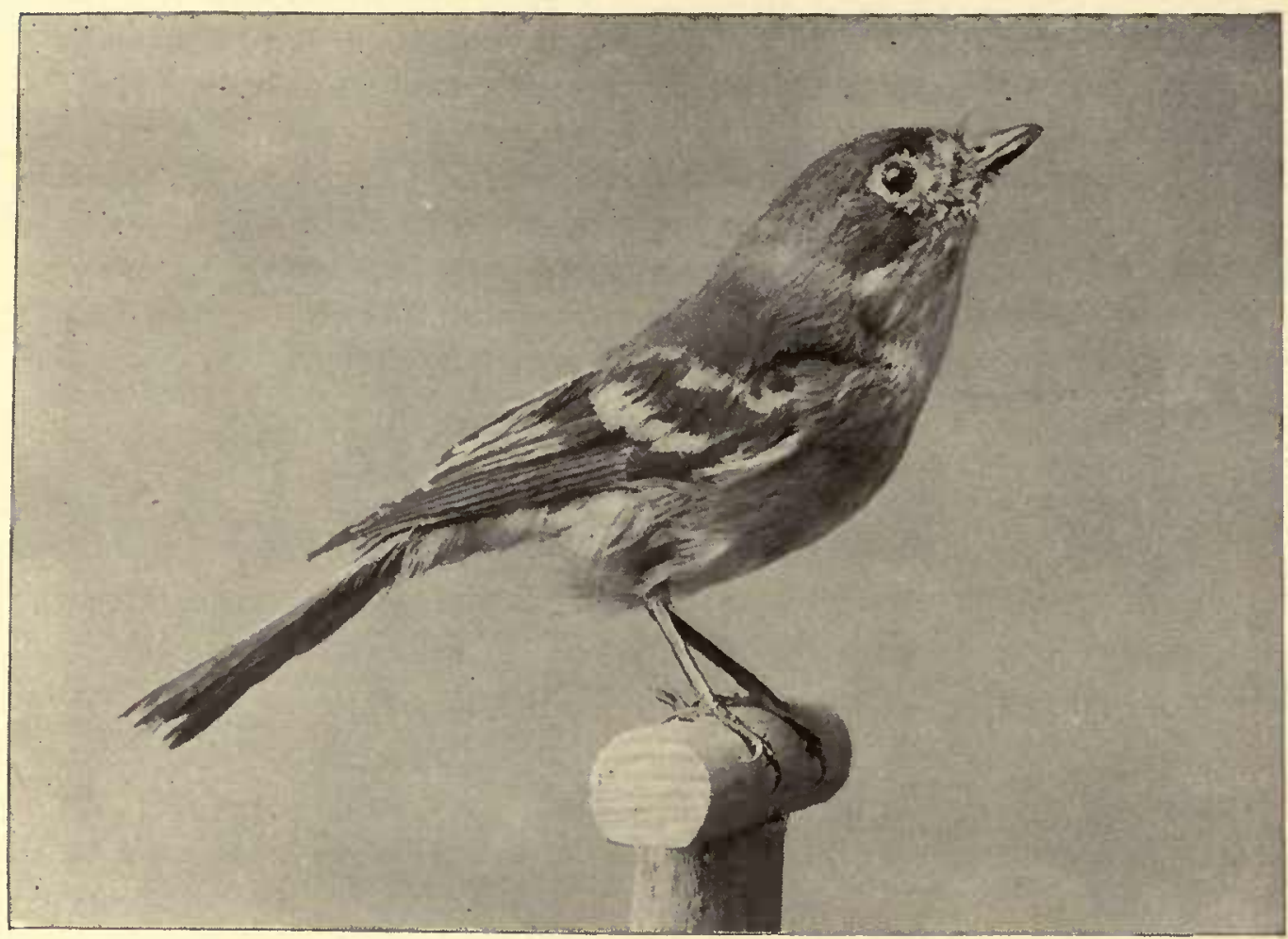


as it goes southward, during most of the month of September. The note is a soft pe-a given in a languid, drawn-out way, suggestive of the first syllable of the Pewee's plaintive utterance.

\section{PLATE XVI.--LEAST FLYCATCHER.}

Empidonax minimus.

Above gray, with a green tinge, darkest on the head and growing lighter towards the rump; beneath dull white, but darker and with olivaceous tinges on the breast and sides; a pale ring around the eye; wings dark, many of the feathers pale-edged; tail dusky, square; bill dark; feet black. Length, 5.40 inches.

Migratory. Arrives early in May, leaves early in October. The nest is usually placed in the crotch of a small tree at no great height from the ground. This little bird frequents orchards or light woods, sometimes even gardens, for it is very sociable. Dr. Brewer makes mention of a pair which built in a honeysuckle attached to his piazza where they reared their brood unmindful of the constant presence of the family. The note is peculiar, and, once heard, will be instantly recognized. It is uttered quickly, and has been written variously as chebec, cadet and sewick. The first is closest to the actual sound. 


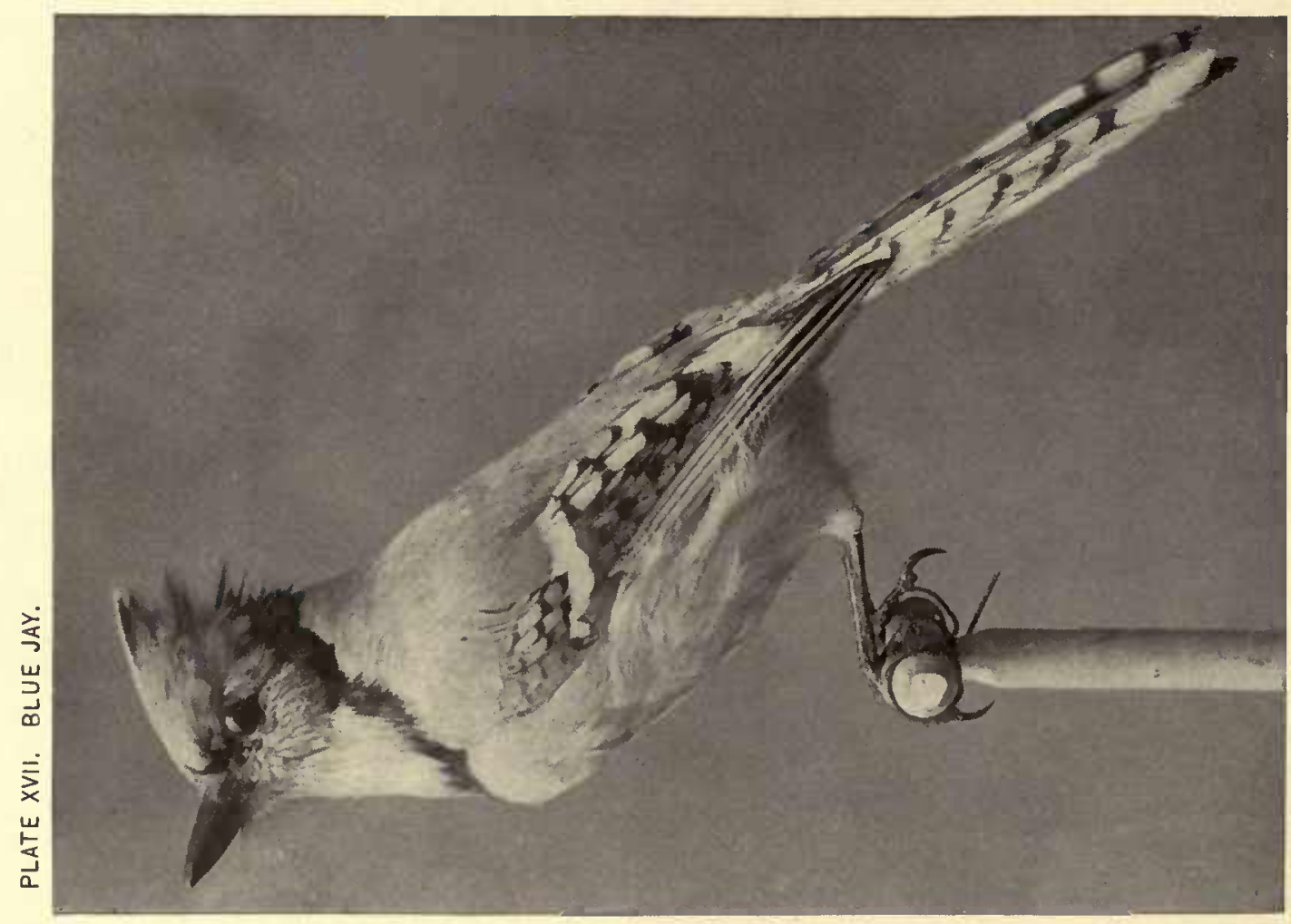




\section{PLATE XVII.-BLUE JAY. \\ Cyanocitta cristata.}

Above light blue; head splendidly crested; cheeks, throat and under-parts bluish white; wings and tail a darker blue, barred with black, and many of the feathers broadly tipped with white; a black band encircles the neck; tail much rounded; mouth, tongue, bill and legs black. Length, 11.75 inches.

A thieving, mischievous, handsome creature. It devours the eggs and young of other birds, and feeds also, upon acorns, chestnuts, berries, fruit, corn, insects, caterpillars, etc. Nests in trees and bushes. Much of great interest has been written about the Blue Jay; see, for example, Thoreau's Succession of Forest Trees; Olive Thorne Miller's A BiRd of AfFAlRs, and an amusing though unscientific chapter in Mark Twain's TRAMP ABROAD.

Samuels says: "Its notes consist of a shrill cry like jay-jay-jay, repeated often and in a high key; a shrill whistle like wheeo-wheeo-wheeo; a hoarse rattle and an exceedingly sweet, bell-like note."

The Blue Jay is a permanent resident here. Although large flocks may be seen traveling southward in the Autumn, the number of the birds does not seem to be diminished in our woods during Winter. The difference, in respect of domiciliation, between 


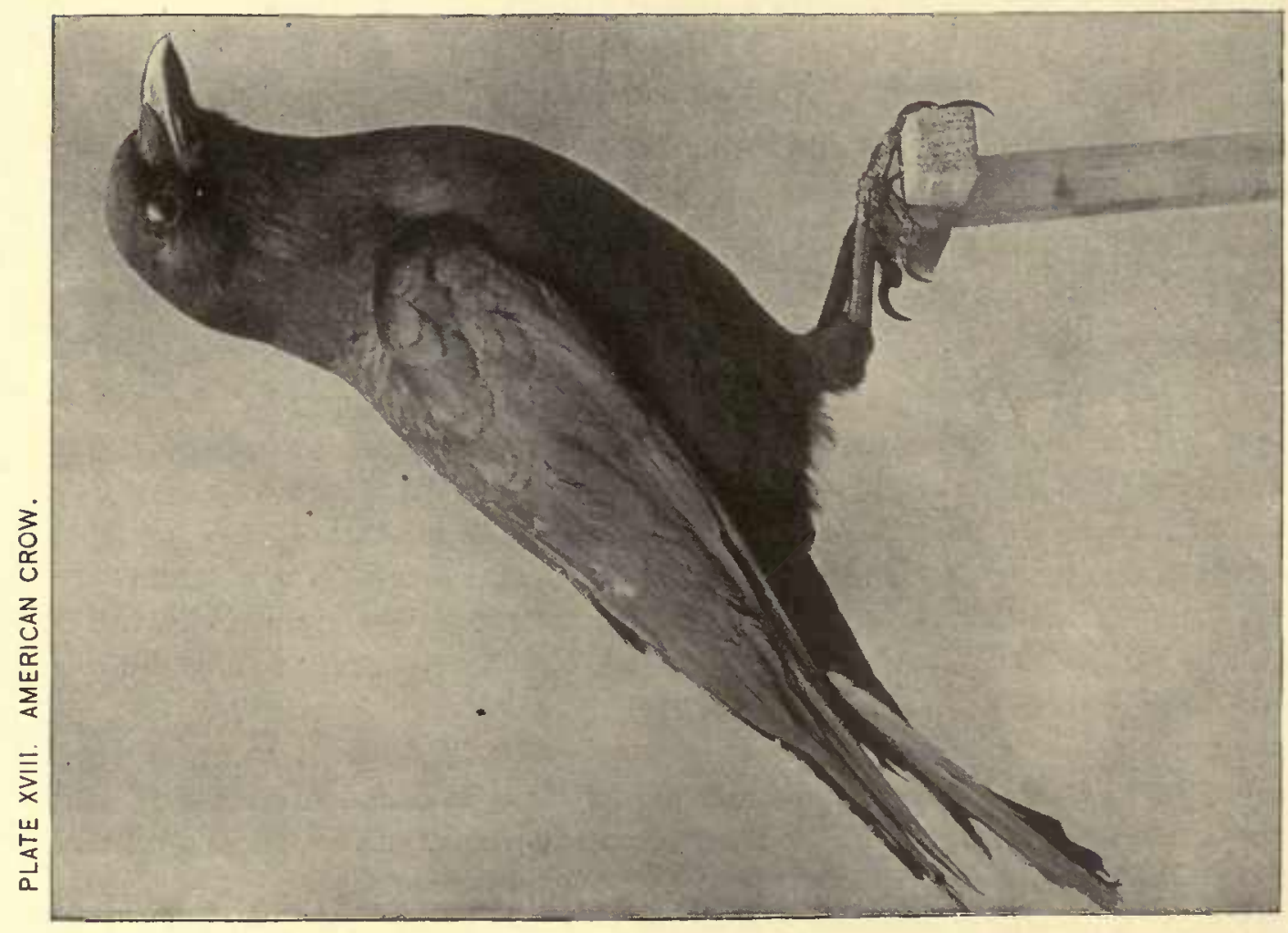


their Summer habits and those of Winter is that, when breeding, the individuals remain constant to one locality; but after the nesting season is done, they roam about, their movements being governed by the distribution of fivorable feeding grounds rather than by an instinct of migration.

\section{PLATE XVIII.-AMERICAN CROW. CROW.}

Corvus americanus.

No description is needed to identify this well-known bird. The following is DeKay's, and is sufficiently explicit: "Black and glossy, with violet reflections. Tail slightly rounded, extending but little beyond the wings. Tail feathers somewhat acute." Length, 19.30 inches.

Resident. Most of the year gregarious; but late in May, it pairs, and breeds. The nest is roughly made of sticks, leaves and grass.

Its hoarse caw is a familiar sound, and, with few varying inflections, is its only utterance. A walker.

\section{HORNED LARK.}

Otocoris alpestris.

Above lilac-brown, the feathers edged with a lighter tinge, and the brown on shoulders and rump redder than elsewhere; forehead, chin, 
PLATE XIX. BOBOLINK.

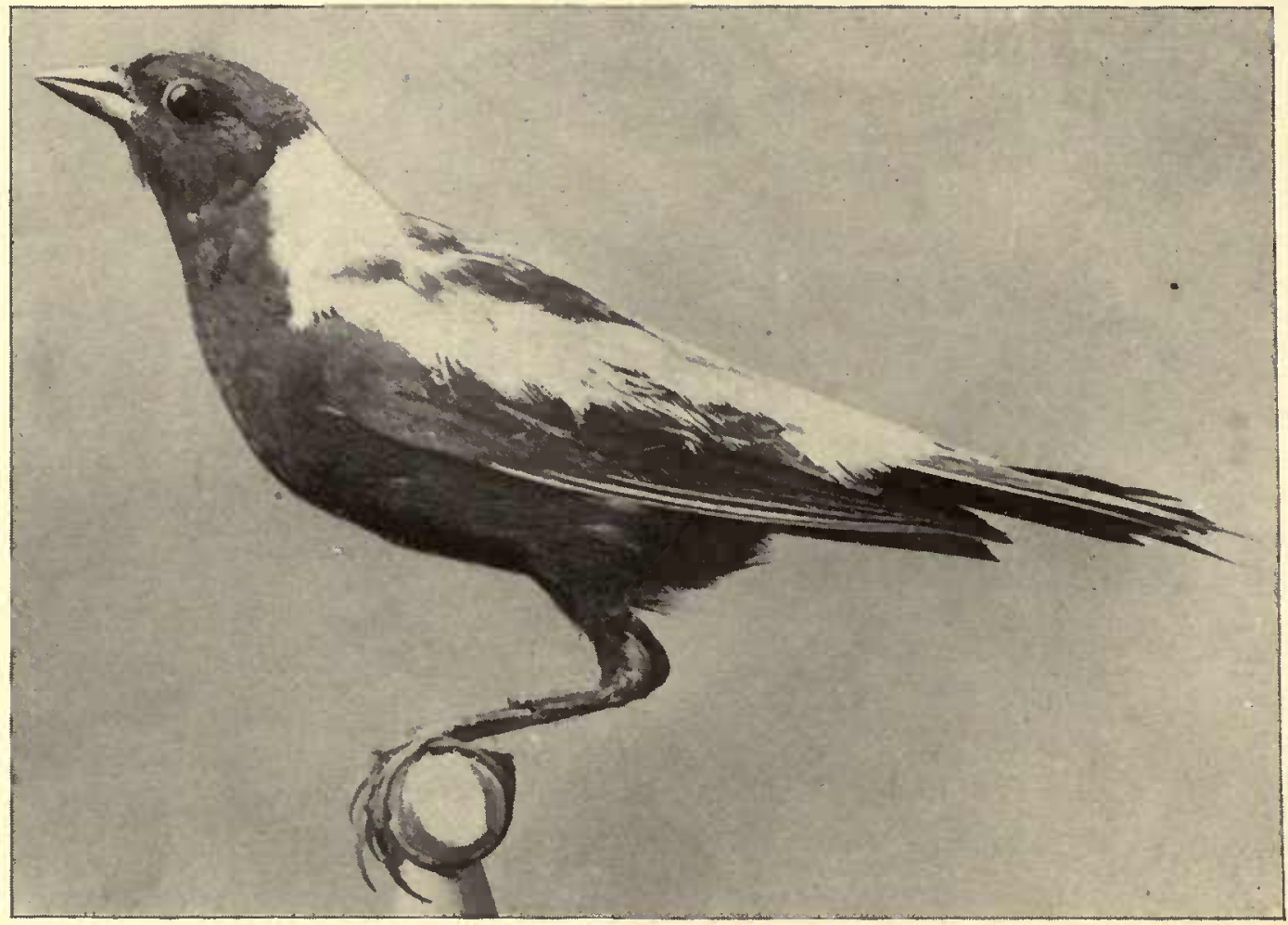


throat, and sides of head yellow; a black stripe commencing at the bill runs back through the eye then downwards on the cheek; a black crescent on the throat; belly white; breast spotted ; sides of body lilacbrown; a black tuft on each side of the head connected by a black band across the crown; wings brown, their feathers somewhat edged and tipped with lighter; tail notched, the middle feathers brown, the others black, but the outermost ones with white edges: bill and feet dark. Length, 7.25 inches.

Migratory. A Winter visitor. Arrives from the north in small flocks in October, returns in March.

\section{PLATE XIX.-BOBOLINK. REEDBIRD.}

Dolichonyx oryzivorus.

In Spring and Summer, breast, wings and tail black; hind neck cream-color; back and rump white; bill and legs brown.

In Fall, yellowish-brown, streaked with darker. Length, 7.55 inches.

Migratory. Arrives early in May, leaves late in September. During the breeding 


\section{PLATE XX. COW'BIRD.}

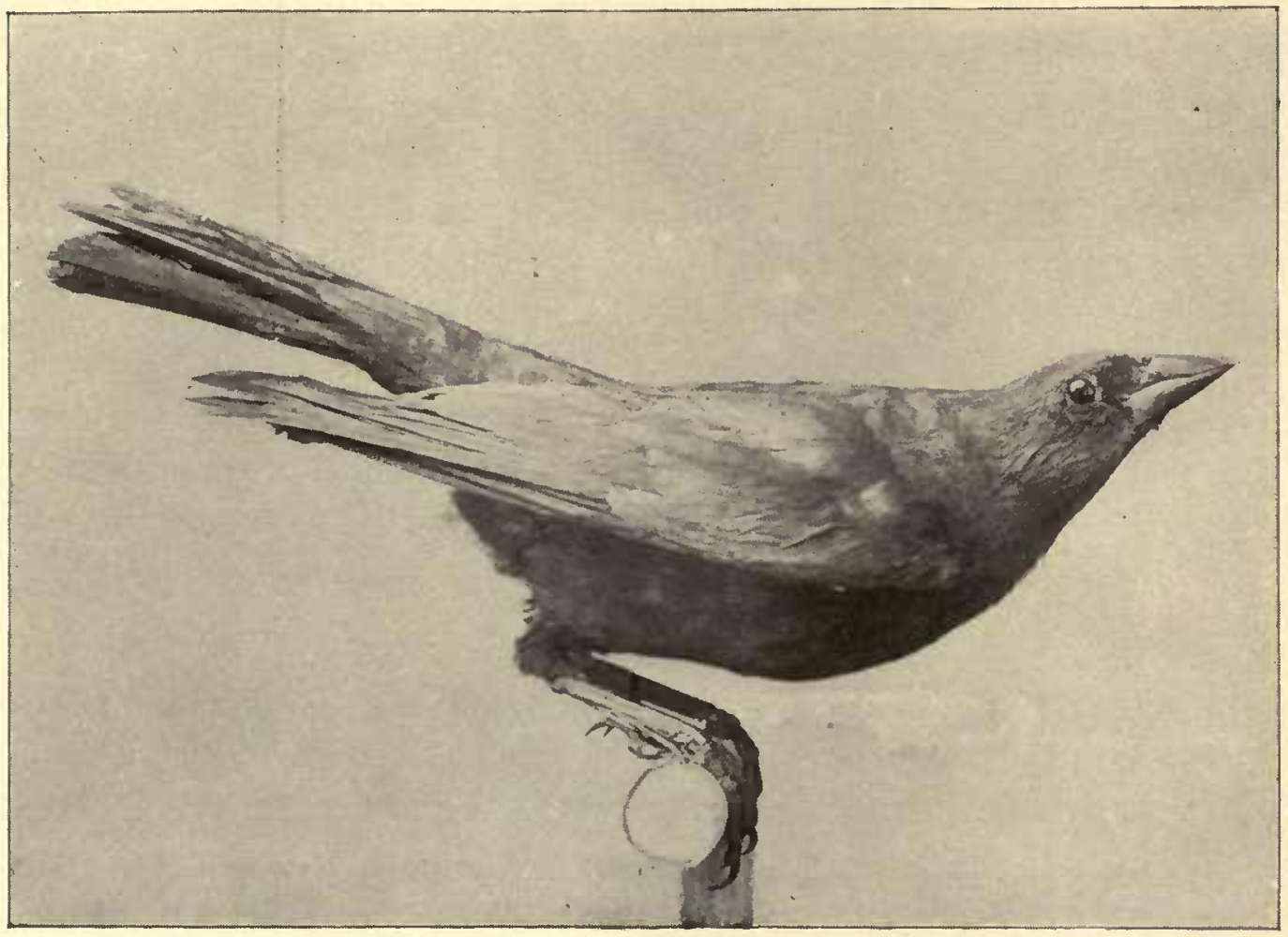


season a vigorous and persistent singer. Samuels calls its song "a most curious, incomprehensible, jingling, roundabout, joyous, laughable medley." When the young have flown, the Bobolink loses its bright plumage and its rollicking song, and indulges for the remainder of its sojourn in nothing more melodious than a peculiar chirp.

A bird of the meadows, and nests upon the ground.

\section{PLATE XX.-COWBIRD.}

\section{Molotbrus ater.}

General color iridescent black; head and neck deep brown; tail square; bill and feet black. Length, 7.90 inches.

Migratory. Arrives early in April, leaves early in October. The Cowbird does not pair, it builds no nest, and the hatching of its eggs is imposed upon some other bird after the fashion of the European Cuckoo. It is, in short, a polygamist, a parasite, and altogether "a bird of loose principles." It is found in flocks, usually in the company of cattle, and has a harsh call, suggesting the syllables cluck-see-see. A walker. 
PLATE XXI. RED.WINGED BLACKBIRD.

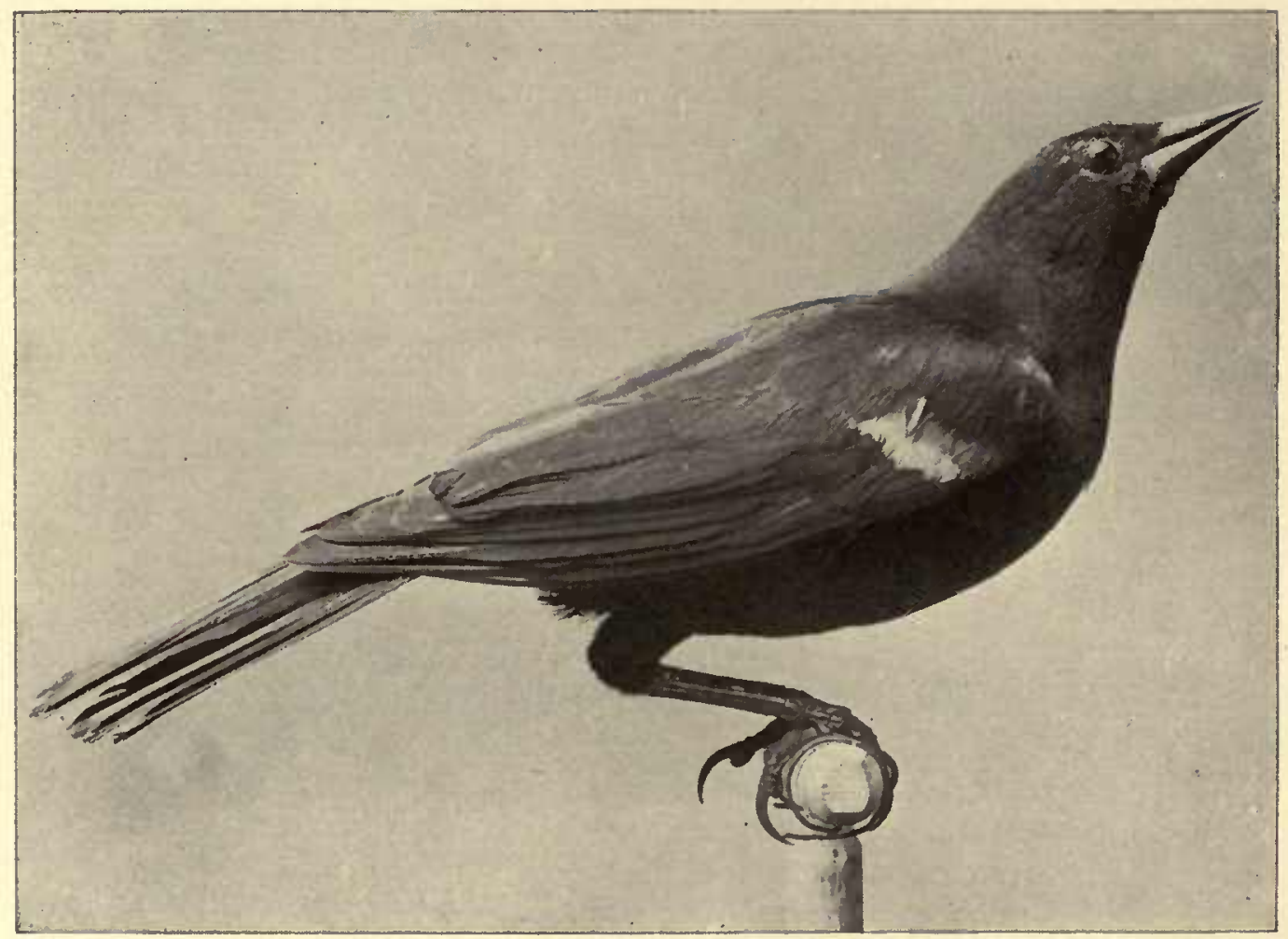




\section{PLATE XXI.-RED-WINGED BLACKBIRD.}

Agelains phoniceus.

General color black, with a greenish lustre; shoulders crimson bordered with buff; tail full and rounded; bill and legs black, the former thick at the base. Length, 9.50 inches.

Migratory. Arrives early in March, leaves early in November. Nests usually in low bushes in meadows or marshes.

After breeding, large flocks collect and are said to consume great quantities of grain. Its call has been rendered quonk-a-ree. A walker. 


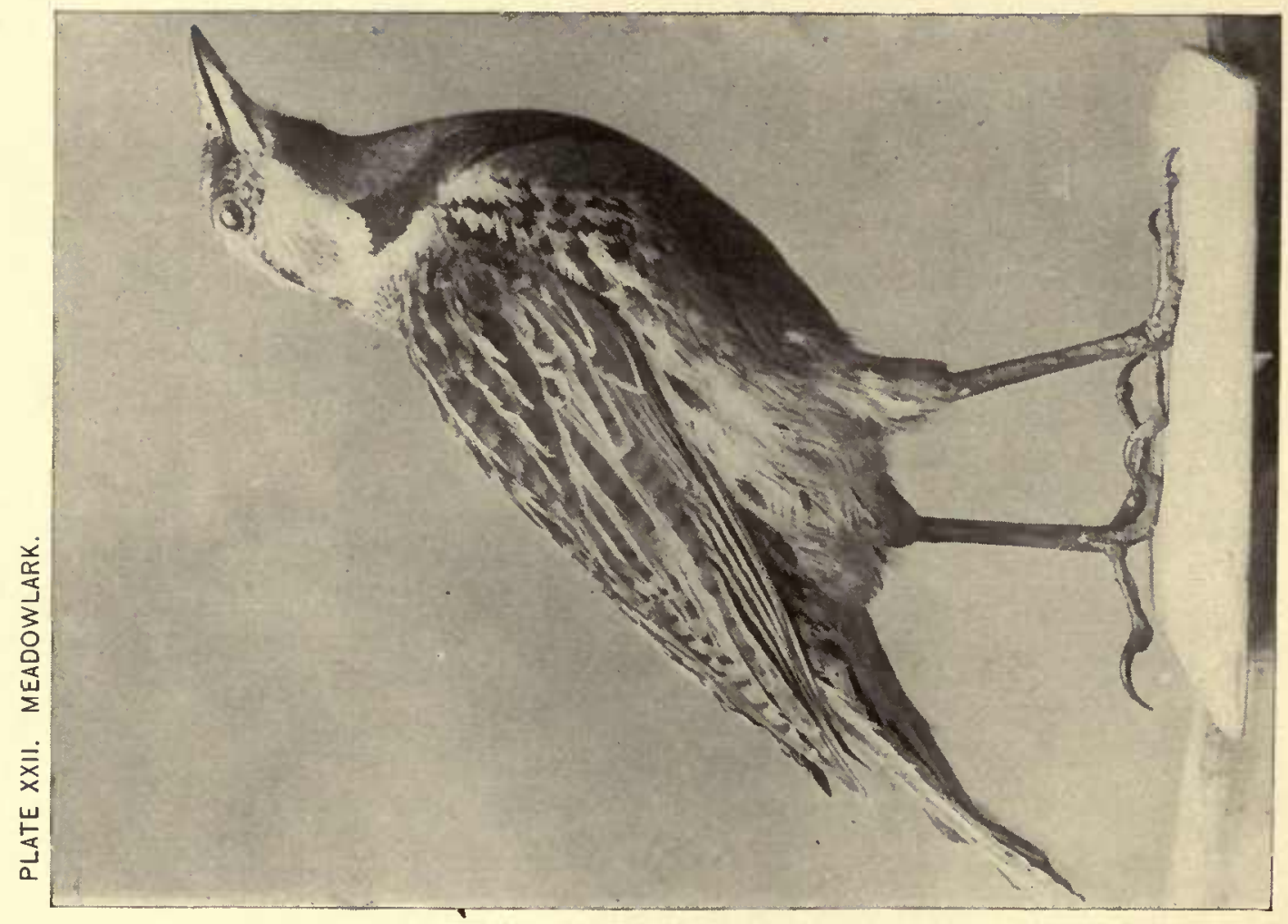




\section{PLATE XXII.-MEADOWLARK.}

\section{Sturnella magna.}

Back brown spotted with black; breast bright yellow, with a large black crescent ; a yellow stripe over the eye and one on the crown; tail feathers pointed, the outer ones white ; legs and feet flesh-color. Length, 10.75 inches.

Resident ; though not numerous in Winter. Most of these birds come late in March and leave late in the Fall.

The Meadowlark nests on the ground in open fields, sometimes in marshes. It is a walker and flies clumsily and with manifest labor. Its note is a plaintive whistle. 
PLATE XXIII. ORCHARD ORIOLE.

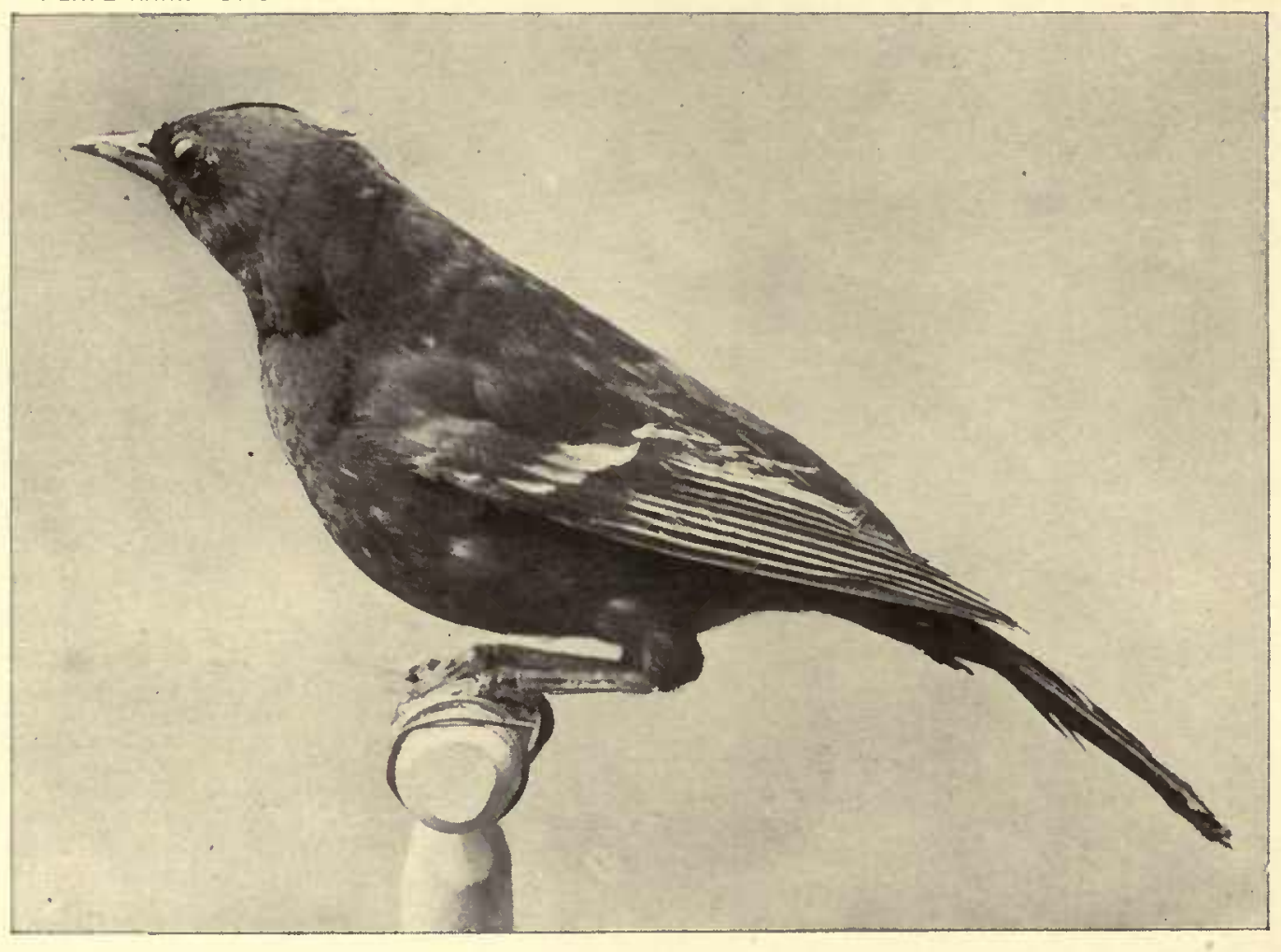




\section{PLATE XXIII.-ORCHARD ORIOLE.}

\section{Icterus spurius.}

Breast and belly chestnut ; head, neck and upper-back black; lowerback chestnut; wings black with chestnut shoulders and a transverse band, some of the quills edged with lighter; tail rounded, black, some of its quills tipped with lighter; bill and feet, dark. Length, 7.30 inches.

Migratory. Arrives early in May, leaves middle of September. Nests in trees, oftenest in orchards. The structure is woven in the same manner as that of the Baltimore Oriole, but unlike the latter, it is placed upon the branch and is not dependent from it. "The Orchard Oriole," to quote Nuttall, "is an exceedingly active, sprightly and restless bird ; in the same instant, almost, he is on the ground after some fallen insect, fluttering amidst the foliage of the trees, prying and springing after his lurking prey ; or flying, and tuning his lively notes in a manner so hurried, rapid and seemingly confused, that the ear is scarce able to thread out the shrill and lively syllables of his agitated ditty. Between these hurried attempts, he also gives others which are distinct and agreeable ; but still his tones are neither so full nor so mellow as those of the brilliant and gay Baltimore." 


\section{BALTIMORE ORIOLE. FIREBIRD.}

Icterus galbula.

Head, neck, throat and upper-back black; lower-back, breast and belly brilliant orange; wings black, with a patch of orange on shoulders, a white transverse band and some tippings and edgings of white; tail full, nearly square, with two large terminal patches of orange; feet and bill black. Length, 7.50 inches.

Migratory. Arrives early in May, leaves about September 15. It builds an elaborate nest, which is, says Nuttall, "a pendulous, cylindrical pouch usually suspended from near the extremities of the high, drooping branches of trees such as the elm, the pear or apple tree, wild cherry, weeping willow, tulip tree or buttonwood."

Its popular name was given it because the black and orange of its plumage were the colors forming the livery of the first Lord Baltimore.

An abundant and beautiful bird, with a piping note, lively and agreeable in quality but limited in scope.

A pair of Baltimore Orioles have made their nest for several successive seasons in an elm near the house in which the writer has passed many Summers, and it is needless to say 
that these birds are always watched with interest, from their advent until their departure. One morning the unusual actions of the female led to the discovery that one of the young, half-fledged nestlings had fallen to the ground, where it was struggling helplessly. It was carefully taken up and a straw was observed protruding from its mouth. The straw had been mostly swallowed, and resisted the gentle force that was used for its extraction. Rather hard pulls were then given, which must have been distressing to that part of the bird's anatomy to which the swallowed end was anchored. At last the straw broke, leaving an end visible, but beyond reach far down the throat, so that nothing more could be done to take it away. A box lined with cotton was then provided, the young bird placed in it, and hauled up close to the nest by means of a string. After this the parent birds were seen feeding, or trying to feed, the sufferer; but all was in vain. The little one died. 


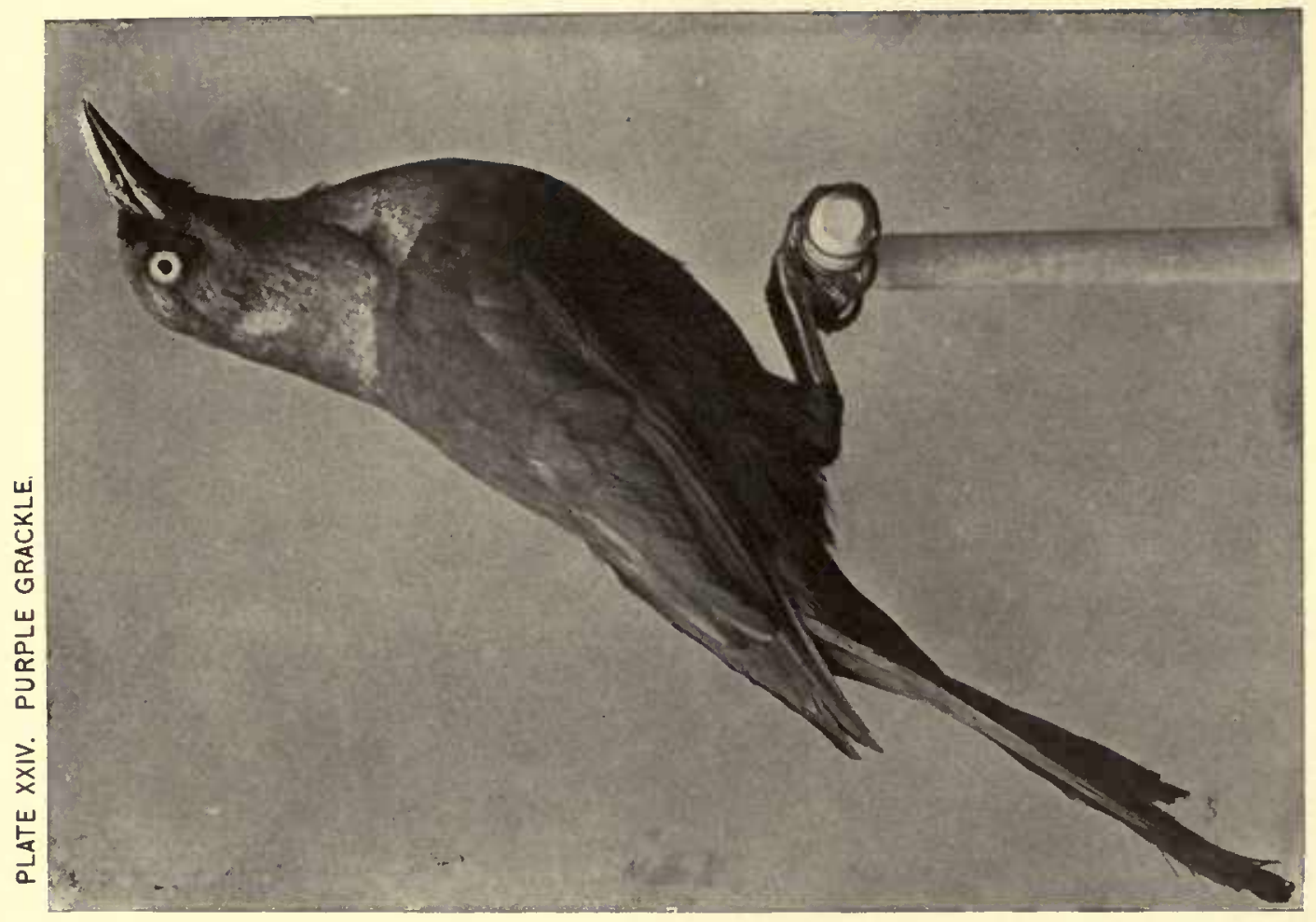




\section{PLATE XXIV.-PURPLE GRACKLE. COMMON CROW BLACKBIRD.}

\section{Quiscalus quiscula.}

Glossy black all over; iridescent on head and neck; tail long and rounded; eyes light yellow; bill and feet black. Length, 12.50 inches.

Migratory. Arrives early in March, leaves early in November. Its nest is a roughly built affair, made of any trash plastered with mud, and is irregularly placed on tree, bush or ground. The bird is gregarious even during the breeding season, but in August it may be seen in immense flocks, in company with equally large numbers of Red-winged Blackbirds foraging in the grain fields, where they create sad havoc. The tail of the Purple Grackle is what is called a keel or boat-tail. It is very much rounded, and during flight the outer quills slant upwards in such fashion as to cause a depression in the centre with a corresponding rise on each side, suggesting, it must be confessed remotely, the keel and sides of a boat.

The bird's notes are harsh and discordant, and many of its attitudes are ungraceful, but, nevertheless, it is not without beauty. The gloss of its black coat and the sheen of purple and violet, green and blue upon its head and breast, compel admiration. A walker. 
PLATE XXV. PURPLE FINCH.

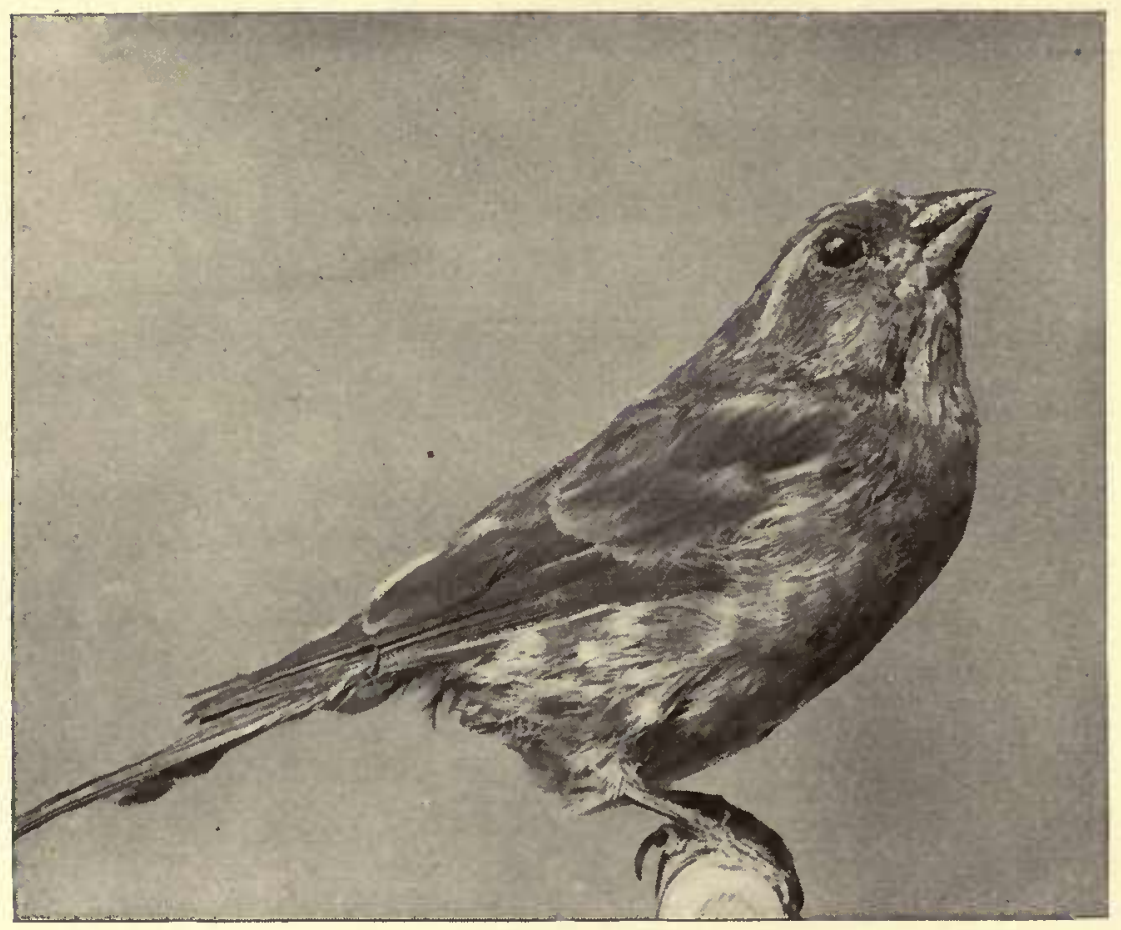




\section{PLATE XXV.-PURPLE FINCH.}

\section{Carpodacus purpureus.}

Body crimson, paler on rump and belly; back streaked with brown; wings, brown, some of the feathers edged with reddish; tail, the same color as the wings, forked; bill conical, horn-color; feet brown. Length, 6.20 inches.

Resident. Nests in trees, sometimes rather high in the branches. It is difficult to say why this bird has been called purple. Dr. Coues writes: "The shade of red is very variable, almost anything but purplish." Mr. Burroughs has caught the purple tint; he says: "The color is peculiar, and looks as if it might have been imparted by dipping a brown bird in diluted pokeberry juice. Two or three more dippings would have made the purple complete."

The song of the Purple Finch is a charming one, which coupled with the gentle deportment and trustful and social disposition of the bird, renders it a general favorite.

During the breeding season it pairs ; but after parental duties are over, it is generally seen only in small flocks. 
PLATE XXVI. AMERICAN CROSSBILL.

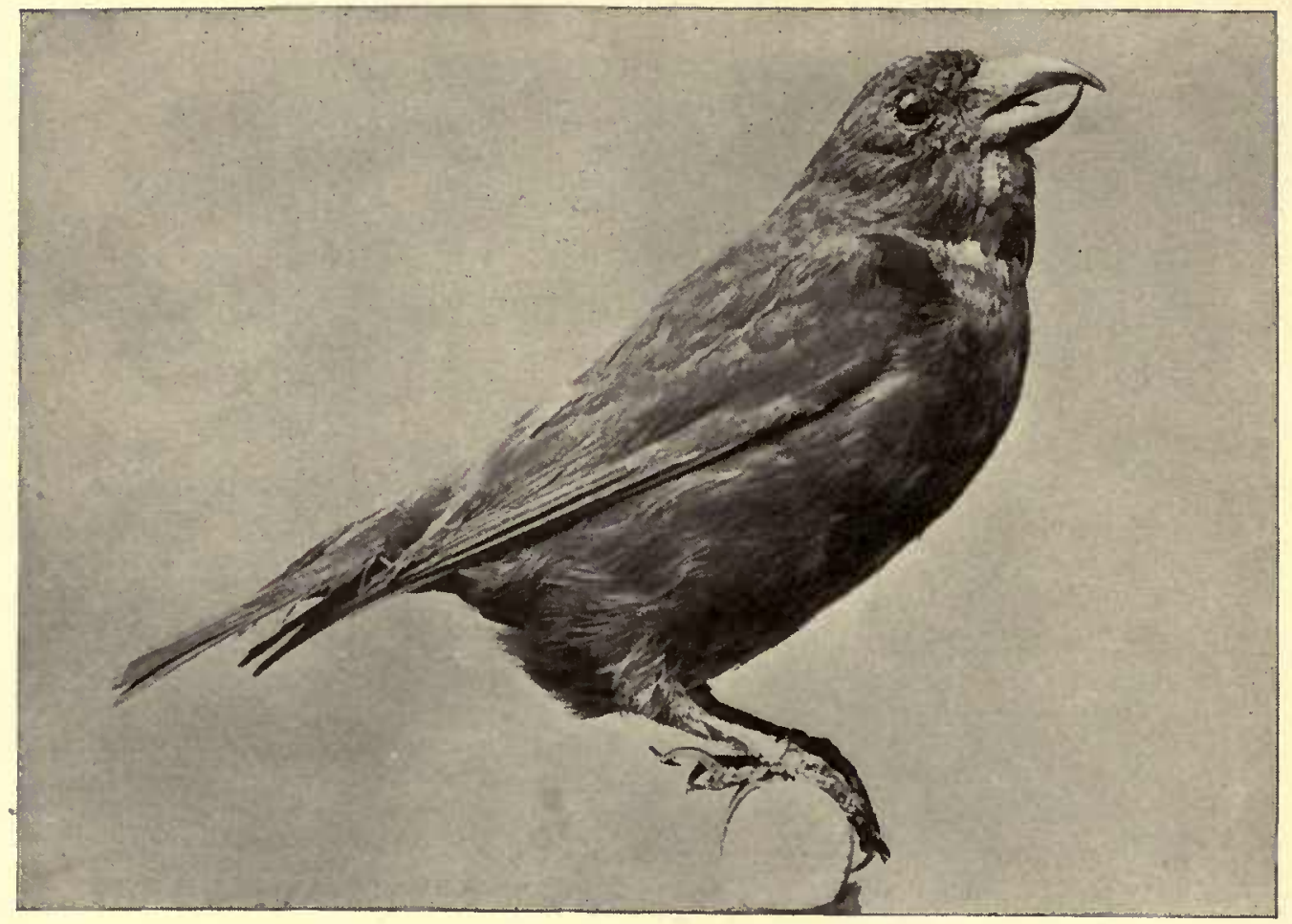




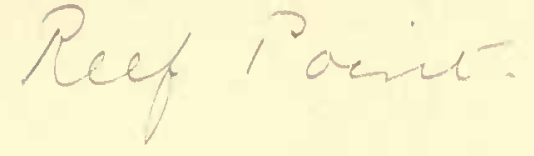

\section{PLATE XXVI.-AMERICAN CROSSBILL. RED CROSSBILL.}

\section{Loxia curvirostra minor.}

General color red; darkest on the back, and with a gray tinge on the belly; wings and tail dark brown, the latter forked; mandibles crossed at tips. Length, 6.20 inches.

"Irregularly migratory," says Dr. Coues, "according to exigencies of weather and food-supply, ** coming southward in flocks in the Fall."

Wilson writes: "On first glancing at the bill of this extraordinary bird, one is apt to pronounce it deformed and monstrous; but on attentively observing the use to which it is applied by the owner, and the dexterity with which he detaches the seeds of the pine-tree from the husks that enclose them, we are obliged to confess ** that no other conformation could have been so excellently adapted to the purpose. ** It has a loud, sharp and not unmusical note. It chatters as it flies." 


\section{AMERICAN GOLDFINCH. YELLOWBIRD. THISTLEBIRD.}

Spinus tristis.

In Summer the body is bright yellow, shading to white towards the tail; crown black; wings black, some of the feathers edged with white; tail the same, slightly forked; bill and feet flesh-color.

In Fall it loses the black on the crown, and the yellow of the body becomes brownish-olive above, grayish-white below, tinged with yellow. Length, 5.10 inches.

Resident. Nests in trees or tall bushes. Flight undulatory. It has several plaintive calls and a song of considerable length but of little power, which is suggestive of the canary.

Care must be taken not to confound the American Goldfinch with the Summer Yellowbird. The two birds are not sufficiently similar in appearance to make this caution needful, but verbal confusion does sometimes occur, because one of the popular names of the American Goldfinch is Yellowbird, while the most commonly used name of the Yellow Warbler is Summer Yellowbird. It would be well if the example of the A. O. U. Check- 
list were followed and one were invariably called the American Goldfinch, and the other the Yellow Warbler.

Although the American Goldfinch is a resident species, and has representatives here both Summer and Winter, as Autumn progresses it will be gradually lost sight of by the observer who is a beginner. But as the Goldfinch has faded from sight, an unfamiliar bird, apparently a new comer, will have challenged attention-a small bird, yellowishwhite beneath and with a greenish-brown back. It will be difficult to believe that this soberly attired bird is the same smart little fellow who was seen in Summer in livery of brightest black and yellow. But so it is ; he has laid aside all brilliancy of plumage. No black remains, and but little yellow. To the superficial observer he is no longer the Goldfinch, but, an unknown, insignificant, uninteresting little brownish bird.

Through the Winter he wears this inconspicuous suit. He remains in flocks. He -roves about, now here now there, where facilities for obtaining food tempt him. But in Spring, when the dandelions show yellow, so does he. Then he no longer roves in flocks, but pairs and builds his nest. Travelling some unfrequented country road you will come across him swaying on a thistle-top in the Summer breeze; or. bounding before you in graceful curves through the air, he will precede you with several short successive flights as you saunter along; no brighter, cheerier, prettier creature alive than he. 
PLATE XXVII. PINE SISKIN.

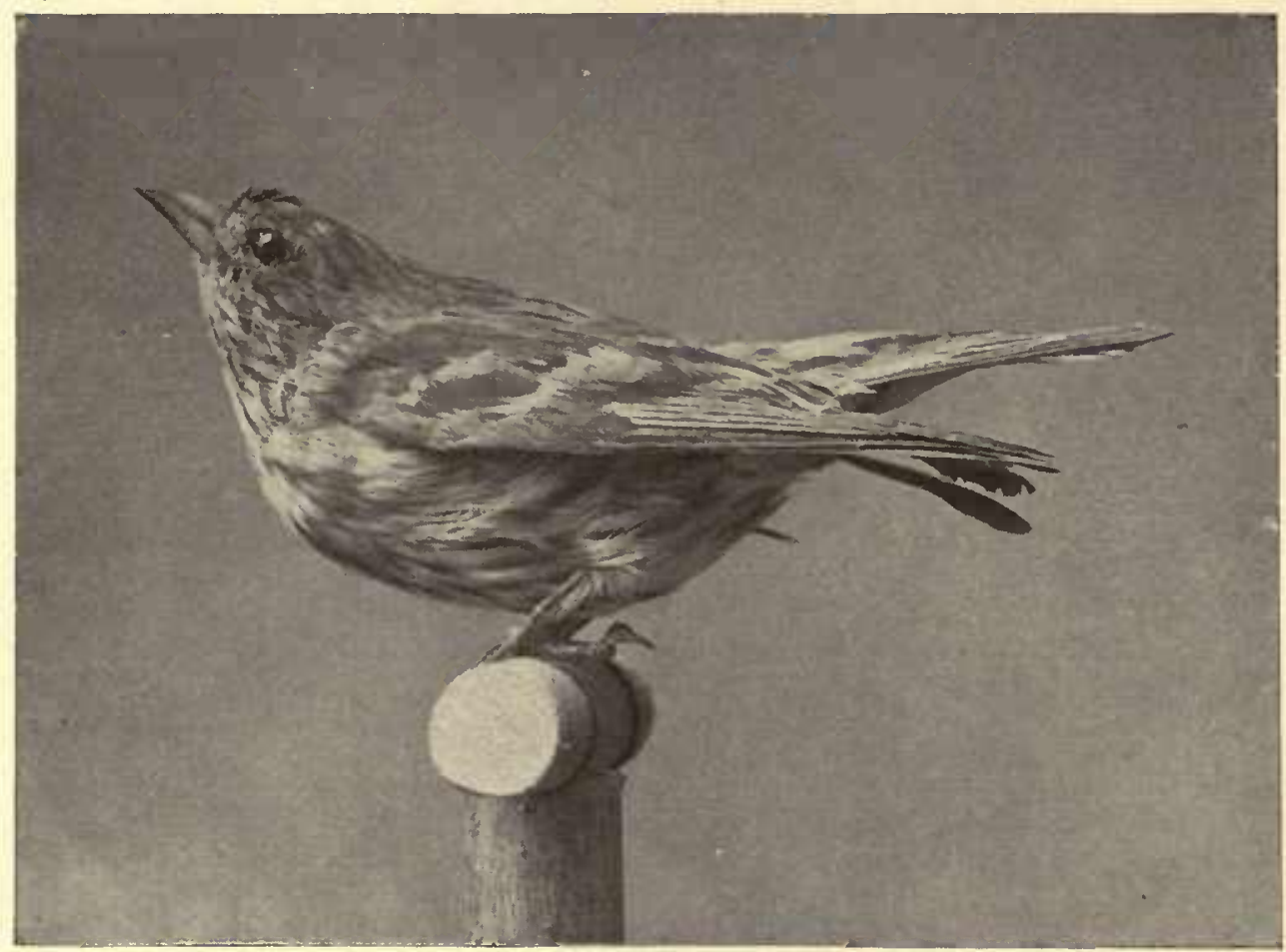




\section{PLATE XXVII.-PINE SISKIN. PINE FINCH. PINE LINNET.}

\section{Spinus pinus.}

Above streaked with greenish-brown and dingy white; beneath dingy white streaked with light brown ; wings dusky, with two light bands and many of the feathers edged with lighter; tail dusky, the feathers with lighter edges, forked; the whole body has a tinge of yellow, most noticeable on the rump and on the tail-feathers; bill and feet brown. Length, 4.75 inches.

Migratory. A Winter visitor, seen here in llocks from October to March. Flight undulatory. Mr. Burroughs describes its song as "singularly secret and elusive * * * delicate and plaintive; a thin, wavering, tremulous whistle, which disappoints one, however, as it ends when it seems only to have begun." He elsewhere calls this Finch : "A dark brown or brindlish bird allied to the common Yellowbird, which it much resembles in its manners and habits." It nests in trees, and, conformably to the suggestion conveyed by its name, oftenest in those of the pine species. 


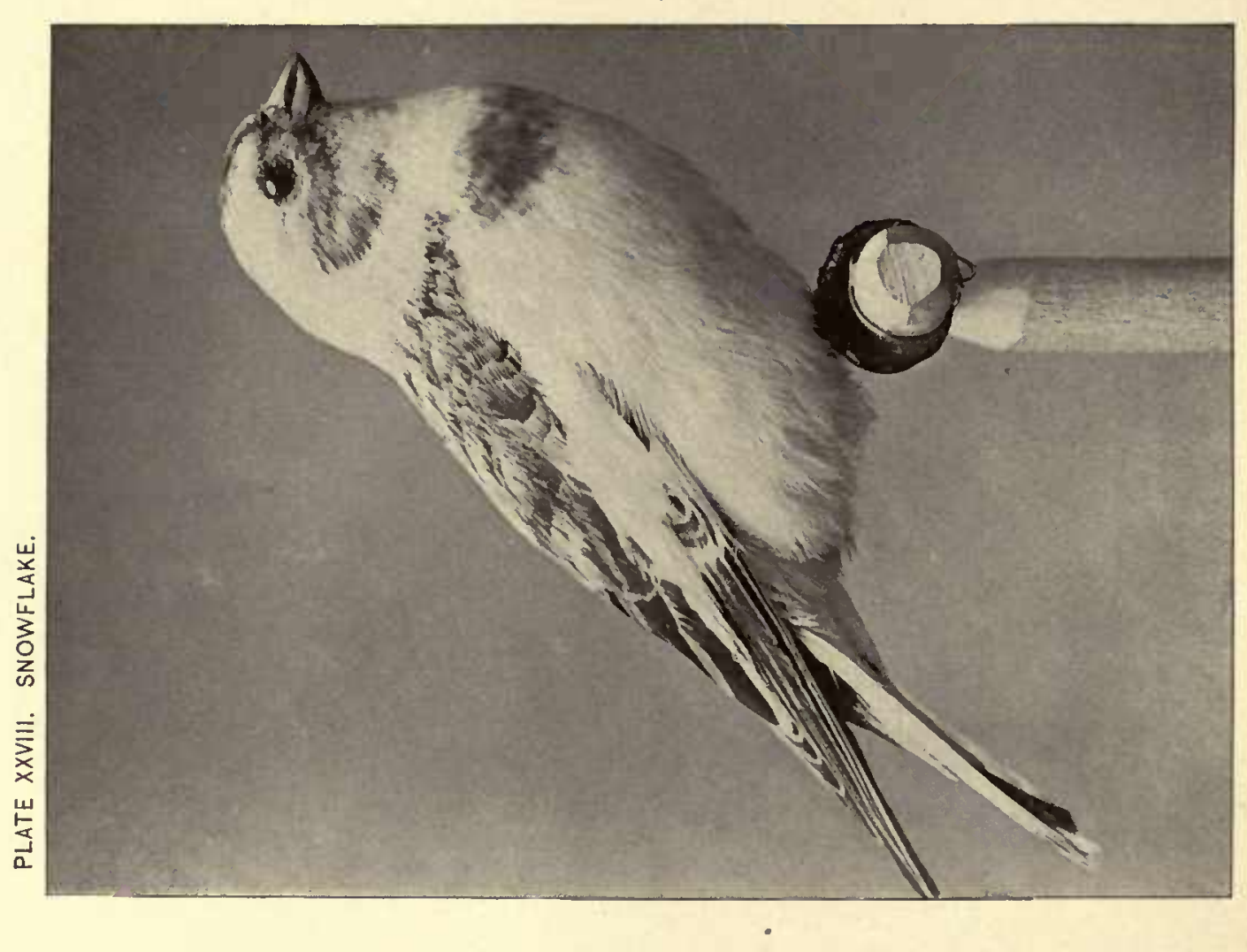




\section{PLATE XXVIII.-SNOWFLAKE. SNOW BUNTING.}

Piectrophenax nivalis.

In full plumage the middle of the back, the two innermost tailfeathers and the ends of some of the wing-feathers black; all else white.

In its Winter plumage, as it is seen here, the white, particularly on the head, is tinged with reddishobrown, and a brown collar almost completely encircles the neck. Bill light; legs dark. Length, 6.90 inches.

Migratory. A Winter visitor, and seen here always in flocks. Breeds in the arctic regions.

\section{FIELD SPARROW.}

Spizella pusilla.

Crown chestnut ; back streaked with dull red, black and dull white ; cheeks, throat and breast pale brown; belly white; a light line over the eye; wings and tail brown, many of the feathers pale-edged-the 
- PLATE XXIX. VESPER SPARROW.

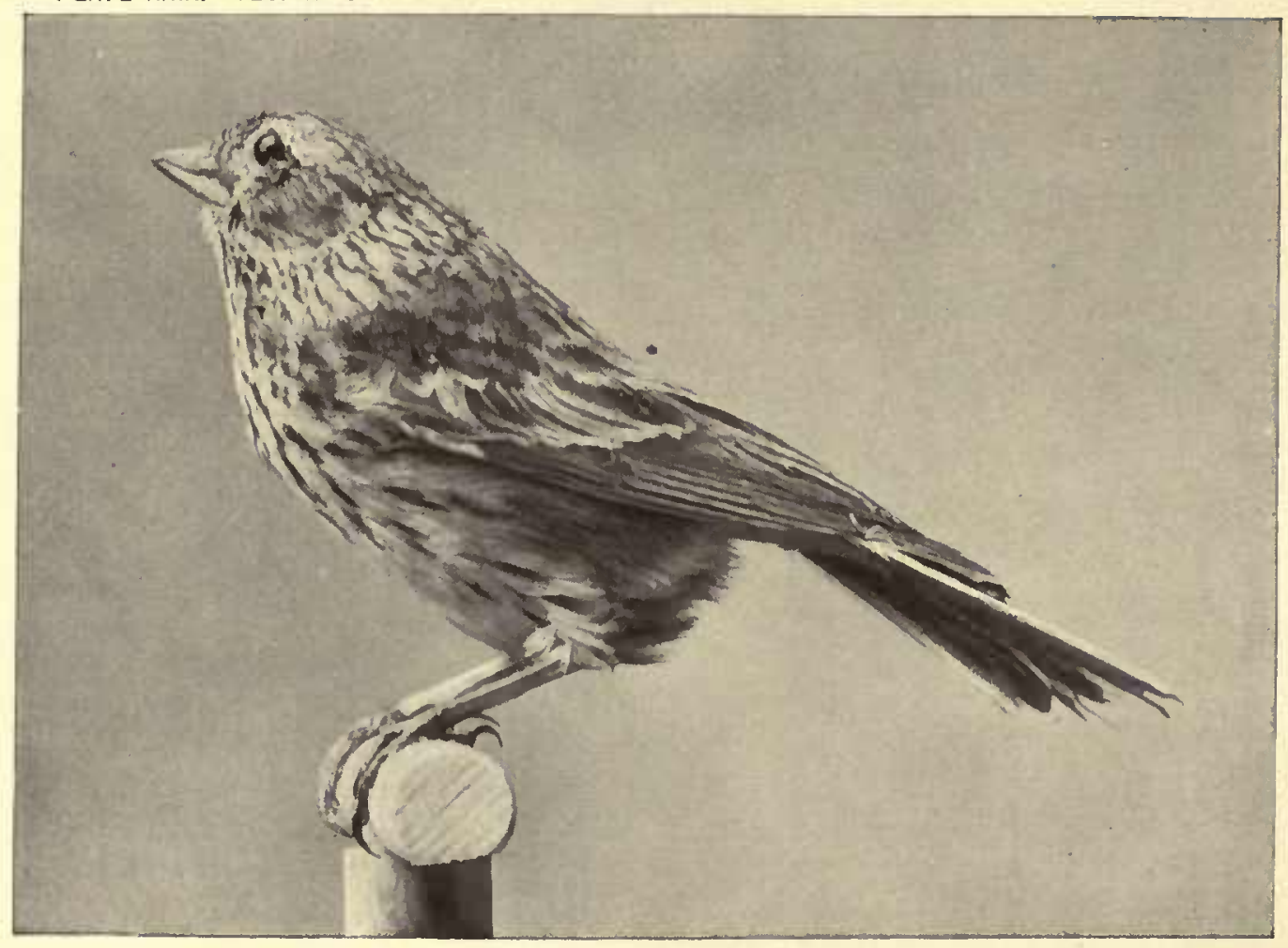


wings with two light bands; bill pale red; feet light. Length, 5.65 inches.

Migratory. Arrives late in April and is seen in flocks inhabiting the open fields and road-sides. In May it pairs and builds a nest which is placed sometimes in low bushes and sometimes upon the ground. At this season its simple song is heard, a warble of little variety, but uttered by the male bird with commendable vigor and persistency, as, perched upon a stump or low branch close by, he watches over his brooding mate. In September flocks are again formed, and, late in October, or early in November, all depart.

\section{PLATE XXIX.-VESPER SPARROW. BAY-WINGED BUNTING. GRASS FINCH.}

\section{Poocates gramineus.}

Above light brown streaked with darker; beneath yellowishwhite streaked on breast and sides with brown; wings light brown, reddis b on the sboulders, and with two pale bands; tail slightly notched, 


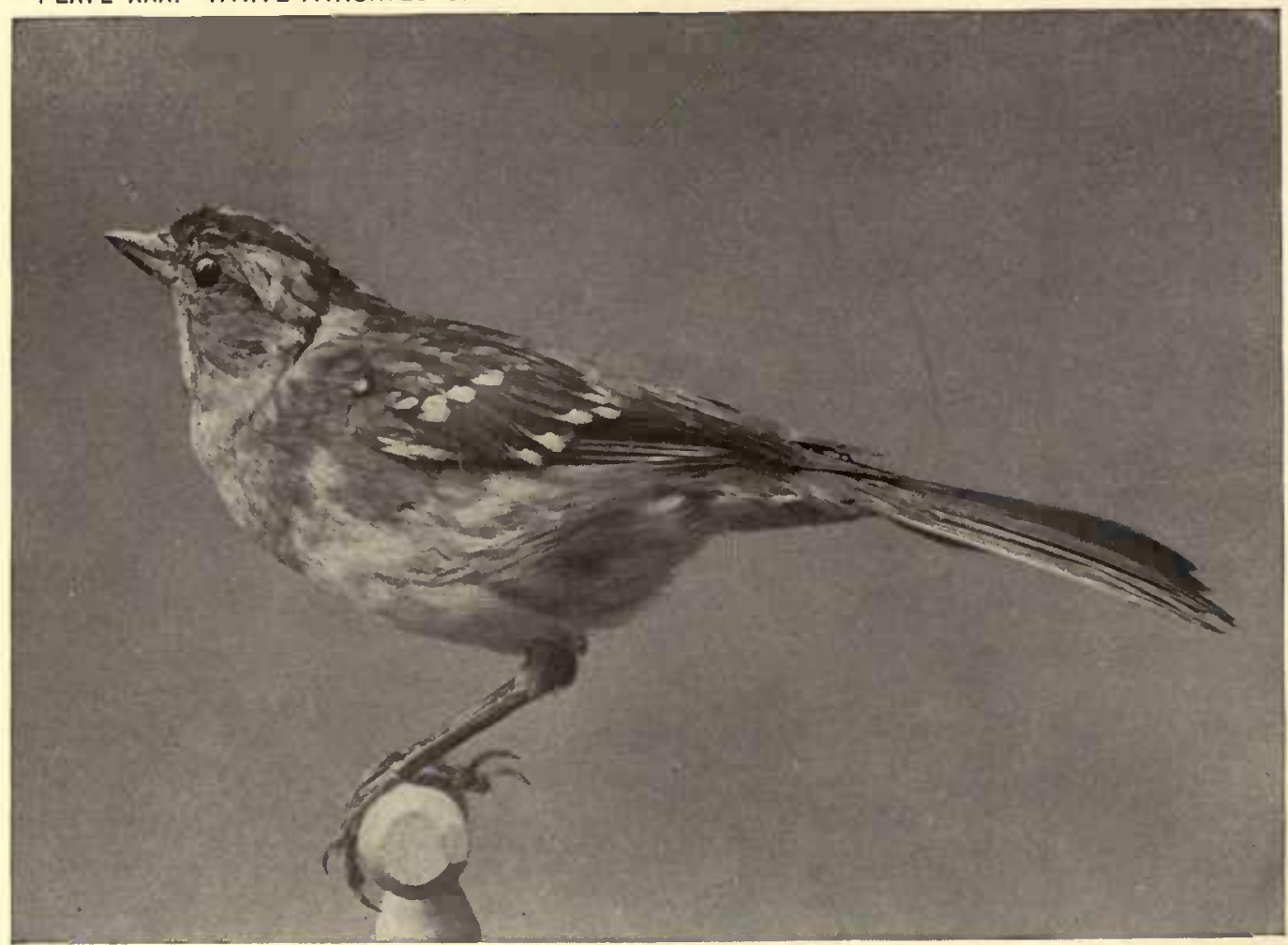


the outermost feathers almost entirely white; bill and feet pale. Length, 6.10 inches.

Migratory. Arrives late in March, leaves early in November. Oftenest found inhabiting up-lying fields and pastures, and along the road-sides. Nests on the ground. Its sweet song, with il likeness to that of the Song Sparrow, is frequently continued until after sunset, whence the pretty name Vesper Sparrow.

"When disturbed by day," Mr. Burroughs writes, "they fly with a quick, sharp movement, showing the two white quills in the tail."

\section{PLATE XXX.-WHITE-THROATED SPARROW. PEABODY BIRD.}

\section{Zonotricbia albicollis.}

Head with one central white stripe, then two black ones, and then two stripes which are yellow from bill to eye and white beyond; cheeks dark ash bordered with black: chin while; breast dark ash shading to white on the belly; back streaked with black, reddish-brown and pale yellow; rump ash; wings reddish-brown, with two transverse white 
bands; tail reddish-brown, slightly rounded; bill dark, feet lighter. Length, 6.75 inches.

Migratory. Abundant during the migratory periods, that is, in Spring, from the 2oth of April to the 2oth of May; and again, in Autumn, from the latter part of September to the middle of November. Through the Summer this Sparrow is not found here; in Winter occasional stragglers are seen. Thoreau, in his MaINE Woods, mentions the song of the White-throated Sparrow as being the bird-note constantly heard by him upon three excursions into the northern part of the state. These excursions were made in Summer, and the places visited were undoubtediy favorite breeding resorts of the bird.

The nest is said to be built upon the ground, and, during its occupancy, the birds pair; but, when the young have flown, they assemble in small flocks and haunt the thickets.

The song, though an agreeable one, is not free from monotony. It has been rendered ee-ee-peabody, and its syllabic suggestions are answerable for one of the bird's popular names. 


\section{GRASSHOPPER SPARROW. YELLOW-WINGED SPARROW. YELLOW-WINGED BUNTING.}

\section{Ammodramus savannarum passerinus.}

Crown black with a central yellowish stripe; back streaked and spotted with black, brown, red and dull white; a light stripe over the eye; breast pale drab, lighter in the centre; belly soiled white; wings dusky, the sboulders edged with yellow; tail dusky, the outer feathers wholly lighter than the inner ones, notched; the feathers of both tail and wings more or less edged with paler; bill stout, short, rather pale ; feet pale. Length, 5.35 inches.

Migratory. Arrives early in May, leaves early in October. Nests on the ground. A frequent but shy and unobtrusive little creature. As you ramble through the fields you will hear his "peculiar, chirring note," and probably will suppose it to be made by some insect; for the sound is very similar to that produced by the grasshopper. It is because of this note that the name Grasshopper Sparrow has been given.

Proceeding on your way, you may chance to catch a glimpse of a small bird flitting 


\section{PLATE XXXI. CHIPPING SPARROW.}

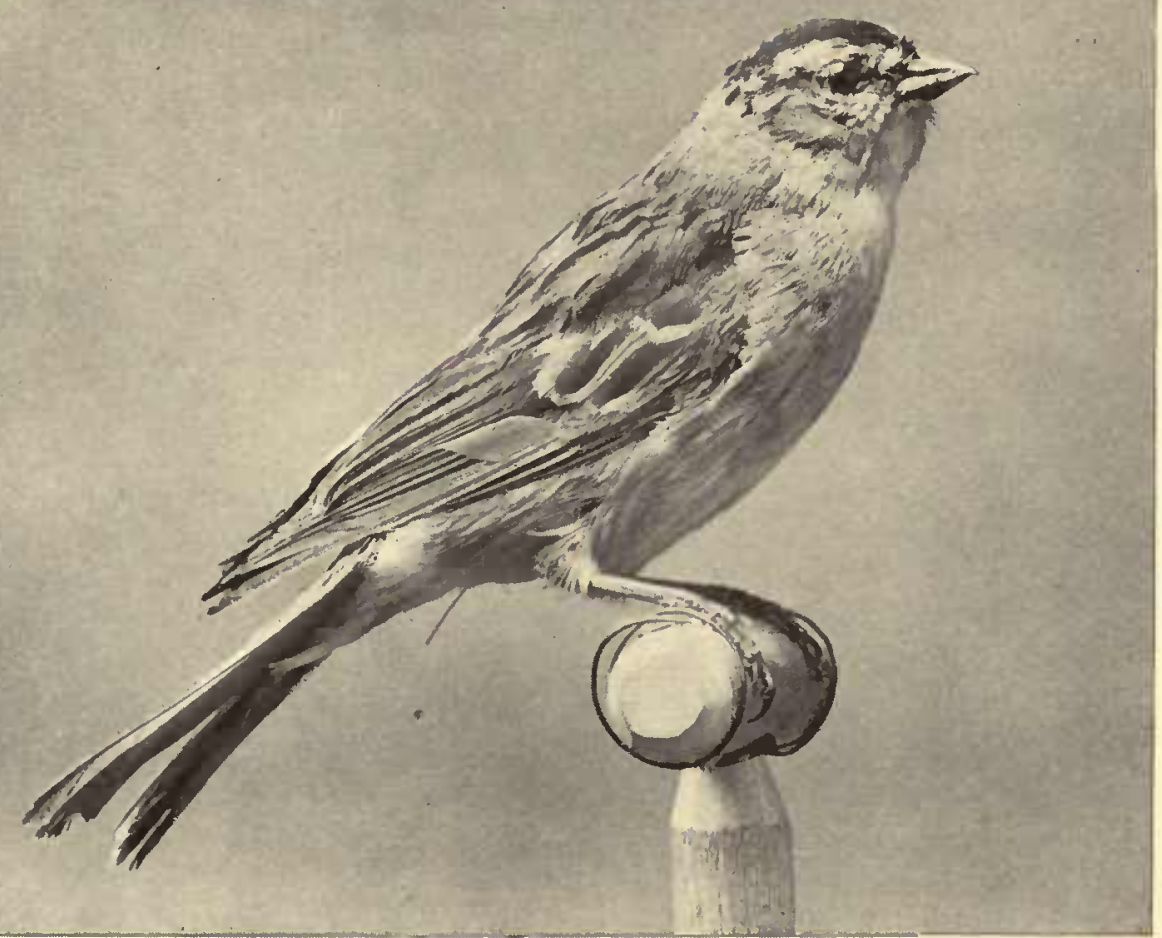


among the taller weeds and grasses with evident desire to avoid notice. This is probably the Grasshopper Sparrow. Set your wits against the bird's, and strive for a nearer and more distinct view. When you are able to detect the back, oddly mottled with black and reddish-brown, the cone-like bill, the crown with its central lateral stripe of pale yellow, and, above all, the bright yellow shoulders, you may set doubts aside; you have established the identity of the bird.

\section{PLATE XXXI.-CHIPPING SPARROW. CHIPPY. HAIR-BIRD.}

\section{Spizella socialis.}

Forehead black; crown chestnut; a light streak over the eye, a black one from base of bill backward through the eye; under-parts and back of neck ash-gray; back streaked with black, brown and dull red; wings and tail dusky, the latter notched; bill short, dark; legs pale. Length, 5.35 inches.

Migratory. Comes early in April, leaves late in October. Builds its nest in trees or bushes, and so constantly employs horse-hair for the purpose that Hair-bird has become one of its popular names. Referring to this habit, Thoreau says: "If I wish for a horse- 
PLATE XXXII. JUNCO.

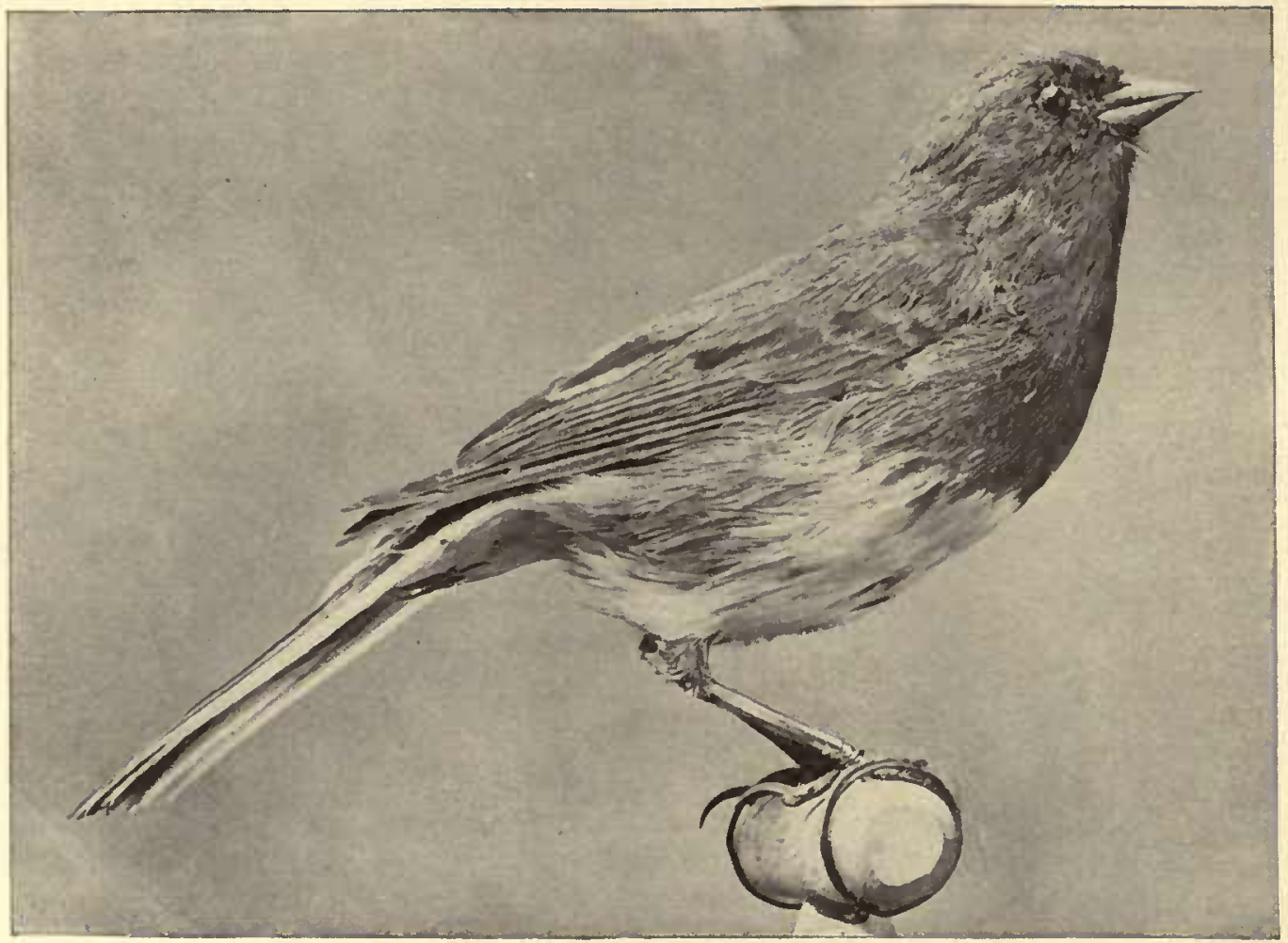


hair for my compass-sight, I must go to the stable ; but the Hair-bird, with her sharp eyes, goes to the road."

Chippy is notably a bird fond of man's society ; at least he finds in the neighborhood of gardens, human habitations and domestic animals the shelter, food and building materials best suited to his wants.

He is one of the first of the birds to come, and among the last to go, and his constant presence about the door-yard in the garden lends more of homeliness and comfort to rural dwellings than he is apt to gain credit for. His note is a trill of considerable duration, suggestive of the sound of the cicada ; certainly not a beautiful song, but because of familiarity and association, one whose loss would be deplored.

\section{PLATE XXXII.-SLATE-COLORED JUNCO. JUNCO. SNOWBIRD.}

Junco byemalis.

Above dark ash; below, throat and breast ash, belly white ; wings and tail dark slate, many of the feathers gray-edged, but the outermost tailfeatbers wbite; bill pinkish-white; length, 6.25 inches; legs ruddy.

Migratory. Common through the winter months, coming from the nortb late in $60+293$
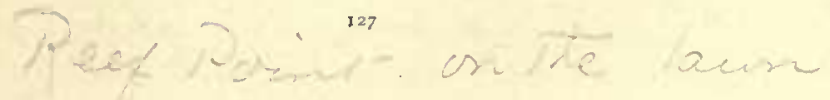
PLATE $X X X I I I$. SONG SPARROW.

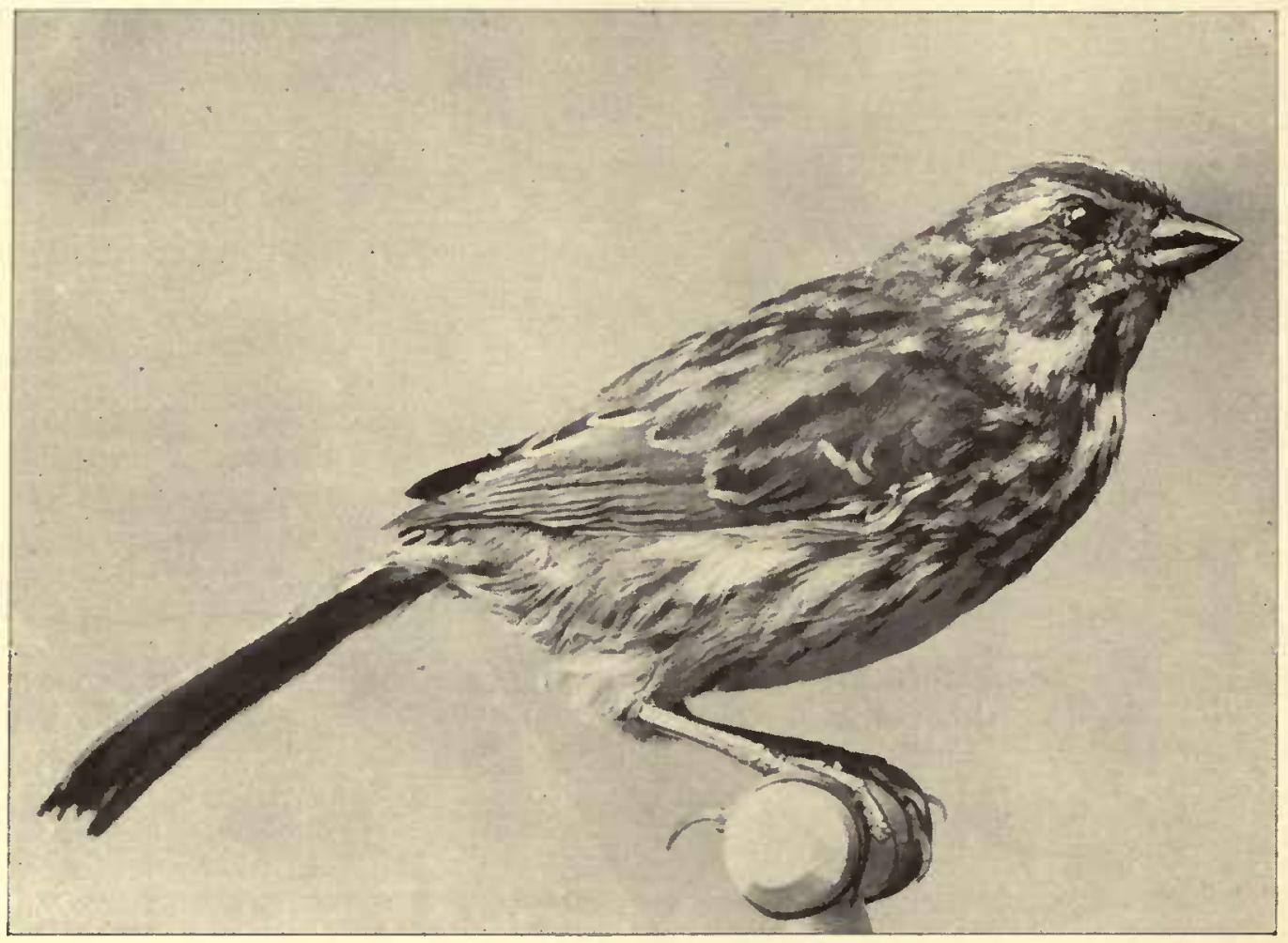


September, and retiring thither to breed late in April or early in May. During its stay here the Junco usually forages in flocks of considerable size, and is seen oftenest by the road-sides. In severe weather, however, and compelled by hunger, it approaches barns and dwellings, and, laying aside its customary timidity, becomes quite fearless.

Its song is not much more than a high-pitched trill and is not often heard.

Probably the bird is more voluble in its northern nesting-places, for only in Spring, just upon the eve of its departure, do we detect the song, and we may reasonably suppose that what we catch is but the preparatory tuning up, so to say, a sort of making ready for the real nuptial chant. It has a call, while with us, which Dr. Coues terms "its snapping note."

\section{PLATE XXXIII.-SONG SPARROW.}

Melospiza fasciata.

Above streaked with black and brown ; crown chestnut with small black stripes: under-parts white streaked with black and brown; a brown stripe behind the eye; wing feathers edged with dull red; tail 
PLATE XXXIV. FOX SPARROW.

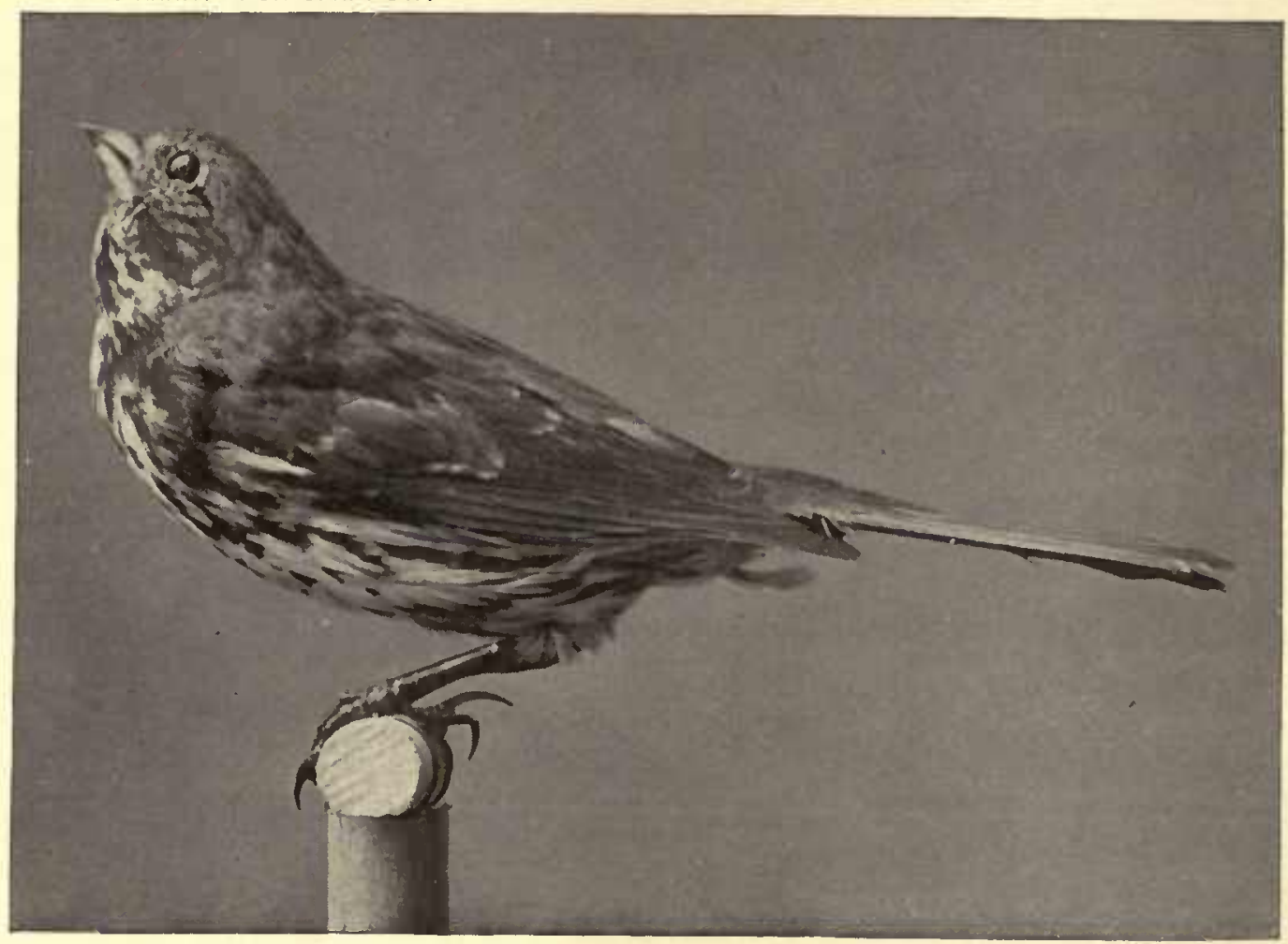


brown, long and nearly even; bill and feet pale brown. Length, 6.30 inches.

A migratory species; though individuals, probably those with the northernmost range, may be found here in Winter. Comes in force early in March and leaves about November I. Has a charming song, one high note thrice repeated, then a canary-like cadenza. This is perhaps the most noticeable song heard in fields and borders of woods, as the bird is abundant everywhere and never wearies of singing. The song, and through it the singer, will easily be identified, notwithstanding that different individuals have a puzzling habit of imparting a good deal of variation to their utterances.

The nest is usually placed upon the ground, sometimes, however, in bushes and even in low trees.

\section{PLA'TE XXXIV.-FOX SPARROW.}

\section{Passerella iliaca.}

Above ash streaked with reddish-brown; below white thickly spotted and dashed with reddish-brown, except on the belly which is un- 
PLATE XXXV. CHEWINK.

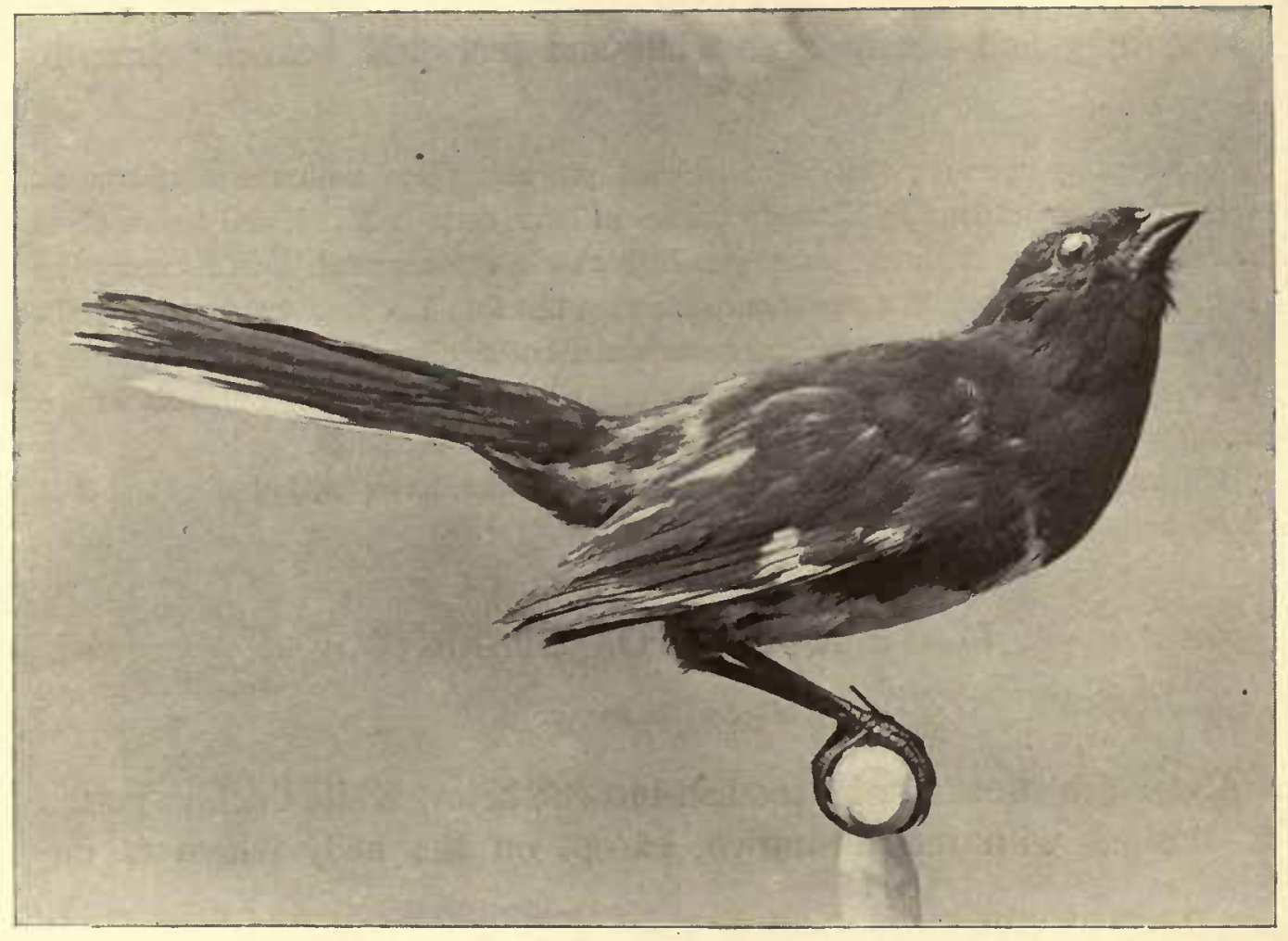


marked; wings and tail bright rufous, the former with two light bands, the latter rounded; bill conical, the lower mandible lighter than the upper one; feet pale. Length, 7.25 inches.

Migratory. Comes early in March, remains until the middle of April, then passes to the north to breed. On its return it is here from the middle of October until the middle of November, when it leaves for the south. The Fox Sparrow is the largest and handsomest of the sparrows, and is also a fine singer. No difficulty need be apprehended in identifying it, for its sparrow-like appearance, its size, color and markings are striking and unmistakable.

\section{PLATE XXXV.-TOWHEE. CHEWINK.}

\section{Pipilo erythrophthalmus.}

Upper-parts, head, neck and upper-breast black; lower-breast and middle of belly white; sides chestnut; wings black with white bands 


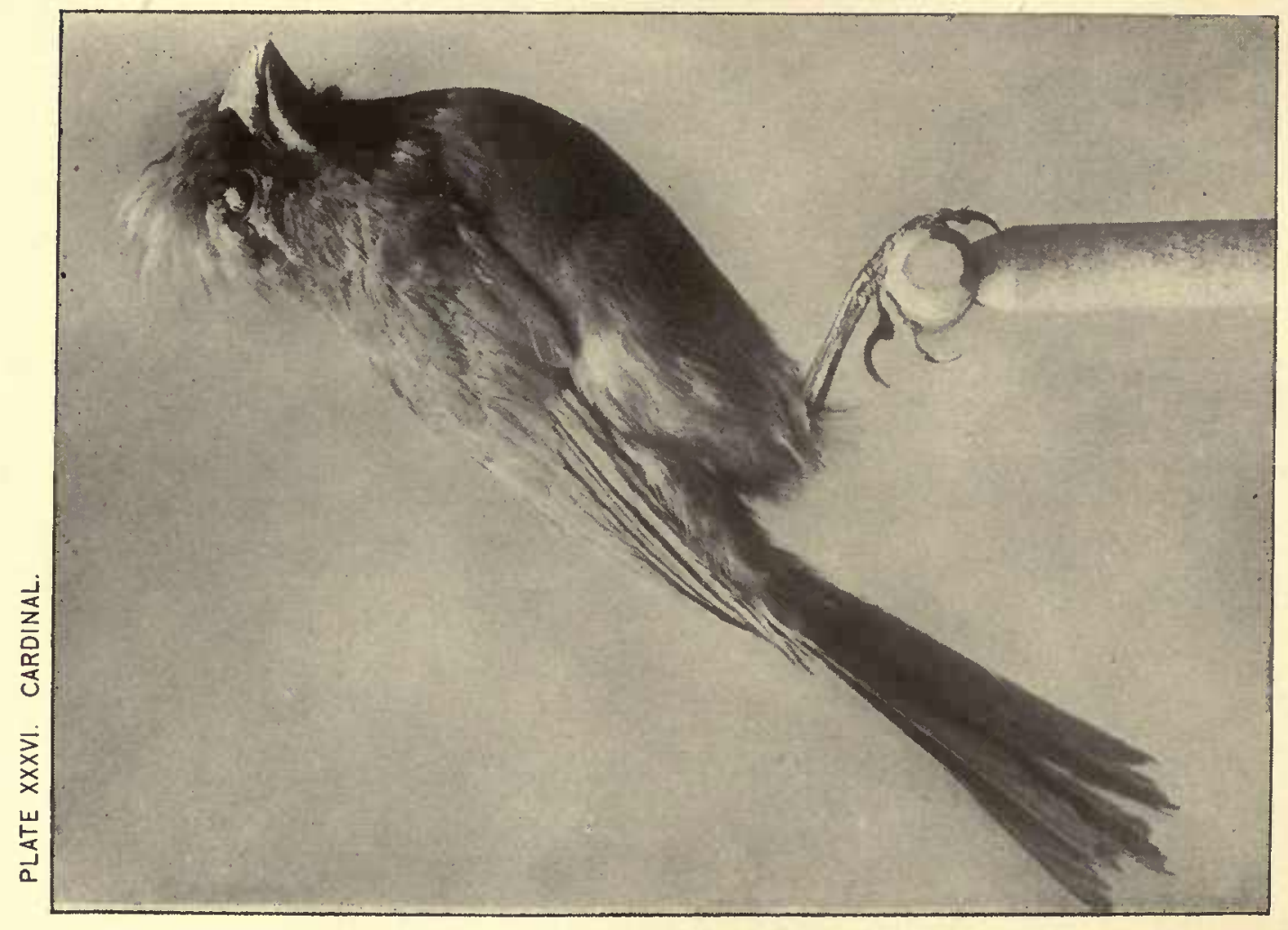


and spots; tail rounded, black, the outer feathers patched with white; bill black; legs brown. Length, 8.35 inches.

Migratory. Arrives middle of April, leaves late in October. Nests on the ground.

Its notes, chewink and towbee, suggest its popular names.

A bird not given to long flights nor fond of lofty situations, but commonly found in thickets or upon the ground scratching among the leaves.

\section{PLATE XXXVI.-CARDINAL GROSBEAK. CARDINAL.}

Cardinalis cardinalis.

Prevailing color red, darker on back; splendidly crested; face and throat black; upper surface of wings and tail grayish, the latter long and nearly square; bill light, tinged with red; feet brown. Length, 8.40 inches.

Migratory. A shy and rather rare, but strikingly handsome, bird. It usually visits us only during the hottest months, and seldom nests so far north as our latitude. Dr. 


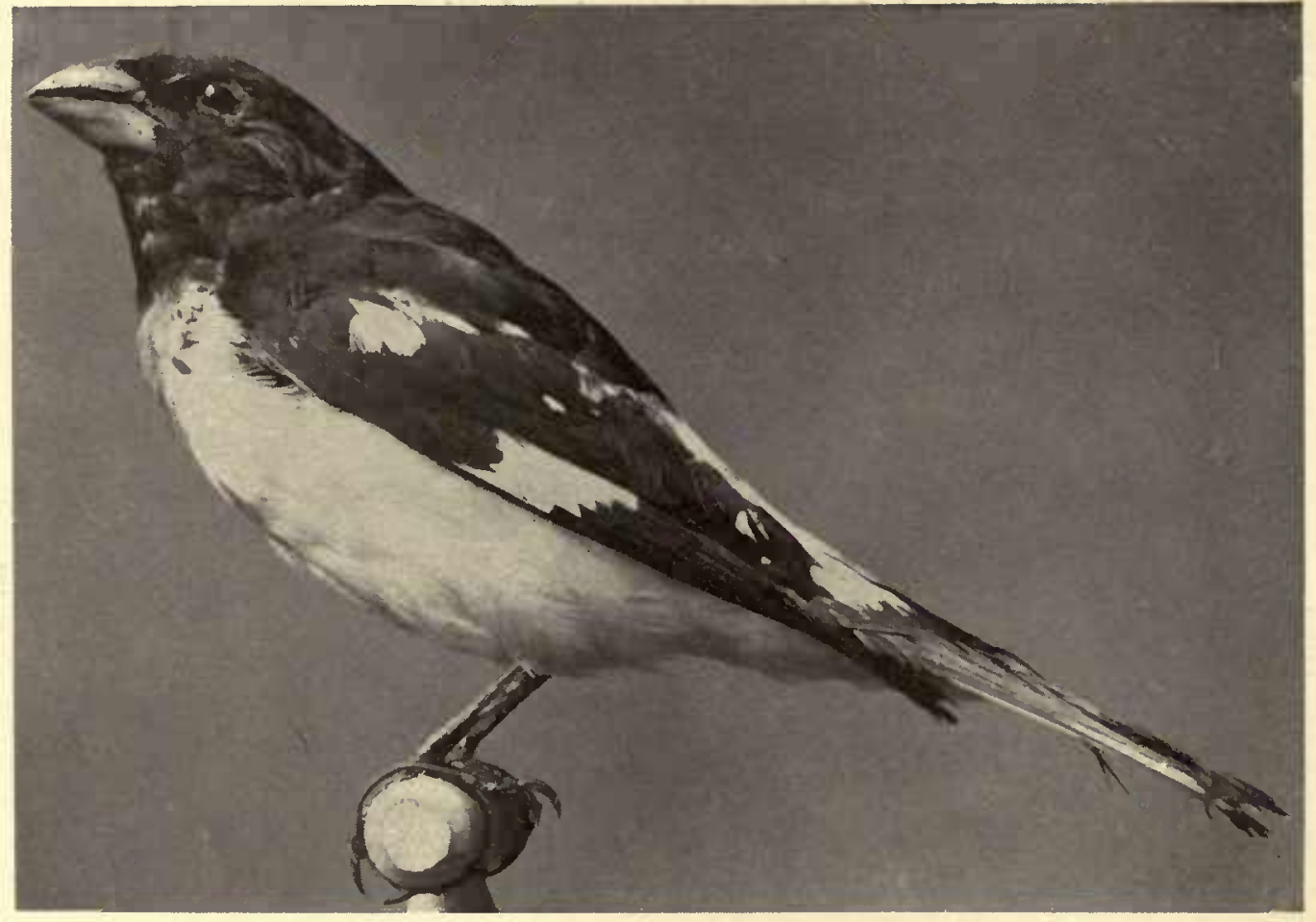


Allen informs me, however, that a small colony has been for some years resident in Central Park, New York City, remaining in Winter and nesting there in Summer.

Dr. Coues describes the Cardinal's notes as "rich, rolling, whistling."

\section{PLATE XXXVII.-ROSE-BREASTED GROSBEAK.}

Habia Indoviciana.

Head, neck, throat and back black; belly and rump white; breast and lining of wings rose-red; wings and tail black, the former with two white bands, tlie latter notched, and patched with white; bill large, conical, light; feet dark. Length, 8.10 inches.

Migratory. Arrives early in May, leaves late in September. Nests in bushes and low trees. Song, "al sweet warble with various emphatic passages, and sometimes a plaintive strain, exceedingly tender and affecting."

A beautiful but rather rare bird ; and the day upon which its acquaintance is made may be justly regarded as a most fortunate one. 
PLATE XXXVIII. SUMMER TANAGER.

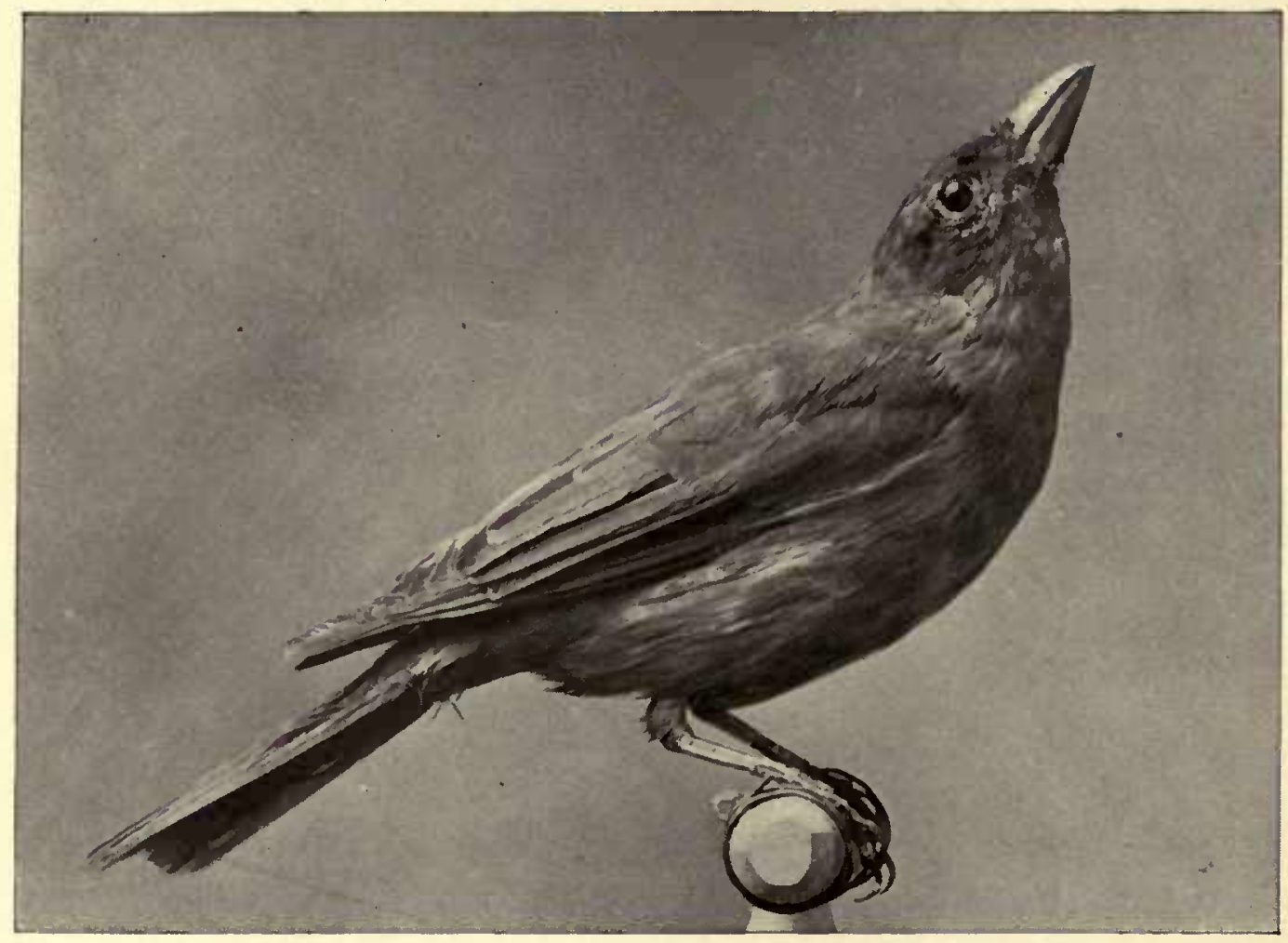




\section{INDIGO BUNTING. INDIGO-BIRD.}

Passerina cyanea.

Blue all over; wings and tail darker than the body; lower mandible paler than the upper one; tail nearly even ; legs dark. Length, 5.55 inches.

Migratory. Arrives late in May, leaves iniddle of September. Nests in bushes. A persistent singer, whose song, of little power or variety, is extremely sweet. The graceful little fellow is rather abundant in lightly wooded country. The lovely blue of his coat, glistening in the sunlight as the bird sits swaying on the tip of a juniper, and the soft tones of his song, afford equal pleasure to the eye and ear of the observer.

\section{PLATE XXXVIII.-SUMMER TANAGER. SUMMER REDBIRD.}

\section{Piranga rubra.}

Red all over, including wings and tail, the red of the wings less 
brilliant than elsewhere; tail square; bill light; legs darker. Length, 7.50 inches.

Migratory. Not a frequent visitor here, though seen oftener some seasons than others, this region being probably about the northernmost limit of its range. It is not so rare a bird, however, that it may not be sought with full confidence of ultimate success.

Like all of the Tanager family, it is an unmusical but handsome bird.

\section{SCARLET TANAGER.}

Piranga erytbromelas.

General color scarlet; wings and tail black, the latter nearly even ; bill pale, legs darker. Length, 7.25 inches.

Migratory. Arrives middle of May, leaves early in October. Nests in trees in woods or orchards. Its song has been thought to resemble that of the Robin, and indeed there is a likeness between the two ; the Robin's excelling, however, in heartiness if not in variety.

The Scarlet Tanager is a bird of gorgeous appearance, and is a conspicuous adornment of the groves which it inhabits. 


\section{PLATE XXXIX.-BARN SWALLOW.}

Chelidon erytbrogaster.

Above steel blue ; throat deep chestnut ; belly light chestnut ; a blue band across the breast; forehead chestnut; wings and tail black and long, the latter deeply forked and spotted with white; bill black; legs purple. Length, 6.95 inches.

Migratory. Arrives late in April, leaves early in September. Its nest of mud and straw is attached to rafters and eaves of houses or barns.

The wonderfully agile and graceful flight of this bird is made the theme of $\mathrm{Mr}$. Ruskin's fascinating essay, Love's MeINE, which will afford the keenest enjoyment to all bird-lovers.

Much discussion has prevailed as to whether the Barn Swallow migrates or hibernates. More than a century ago Gilbert White was full of speculation regarding it, as many pages of his Natural. History of Selborne show.

Dr. Chas. C. Abbott, in A Naturalist's Rambles About Home, has devoted an interesting chapter to the subject; and, indeed, writers on birds have all found the theme a 


\section{PLATE $X X X I X$. BARN SWALLOW.}

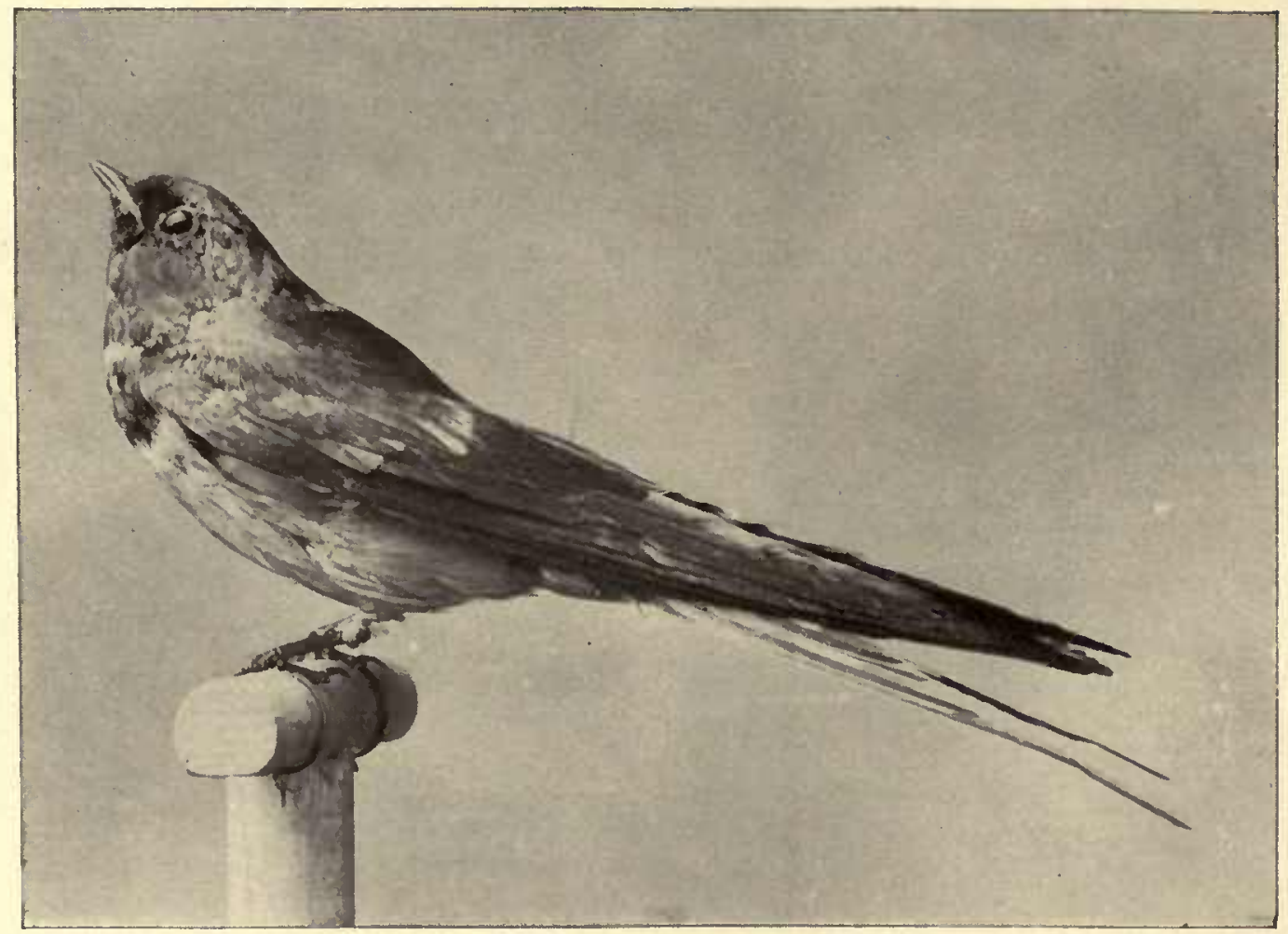


fruitful one for argument. The consensus of expert opinion at the present day is against hibernation, but there are, nevertheless, ornithologists who are not convinced; while nearly all uneducated rural observers assert that in Winter the Swallow retires to a pond, where, sinking into its depths, he rolls himself in a mud casing or shell, and in a state of torpidity, awaits the coming of Spring.

It is strange that such a curious belief, unsupported by evidence, should take possession of men's minds ; but the conviction of hibernation in this manner on the part of the Swallow is certainly common, and is, say most eminent ornithologists, totally unsubstantiated by proof.

Mr. Bicknell calls the song of the Barn Swallow "a low, chattering trill * * often terminating with a clear, liquid note * * not unlike one of the notes of a Canary." 
PLATE XL. BANK SWALLOWW.

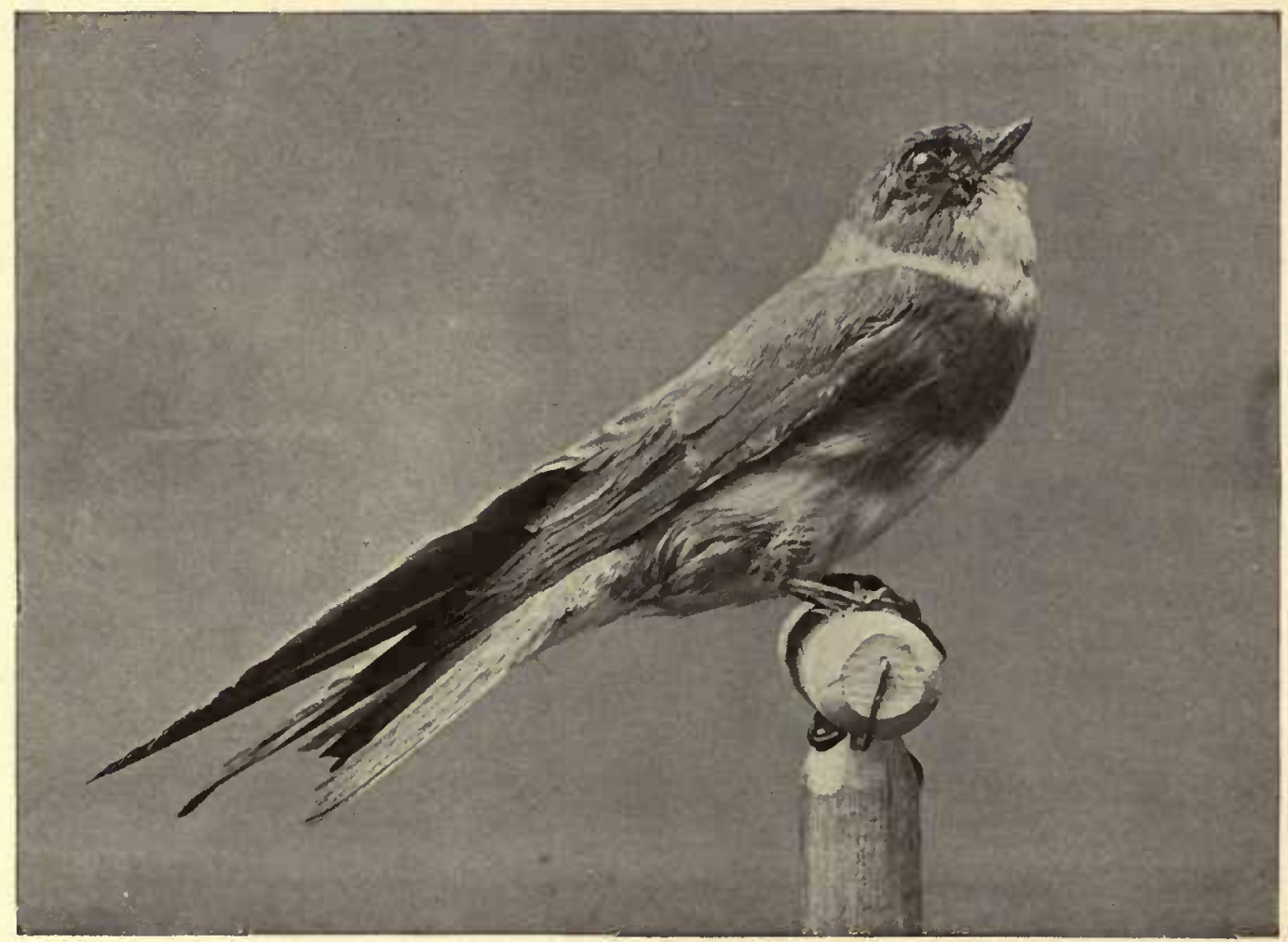




\section{PLATE XL.-BANK SWALLOW.}

\section{Clivicola riparia.}

Above gray-brown; beneath white, with a brown band across the breast; wings and tail darker than body (the tail nearly square); bill dark; feet lighter. Length, 5.20 inches.

Migratory. Arrives about May 20, leaves in September. The Bank Swallow is recorded as seen in large numbers in Rockland County, New York, so late as November, but this is exceptional. Its nest is placed in a hole excavated in a sand-bank. Lives in colonies. Note soft and lisping. 


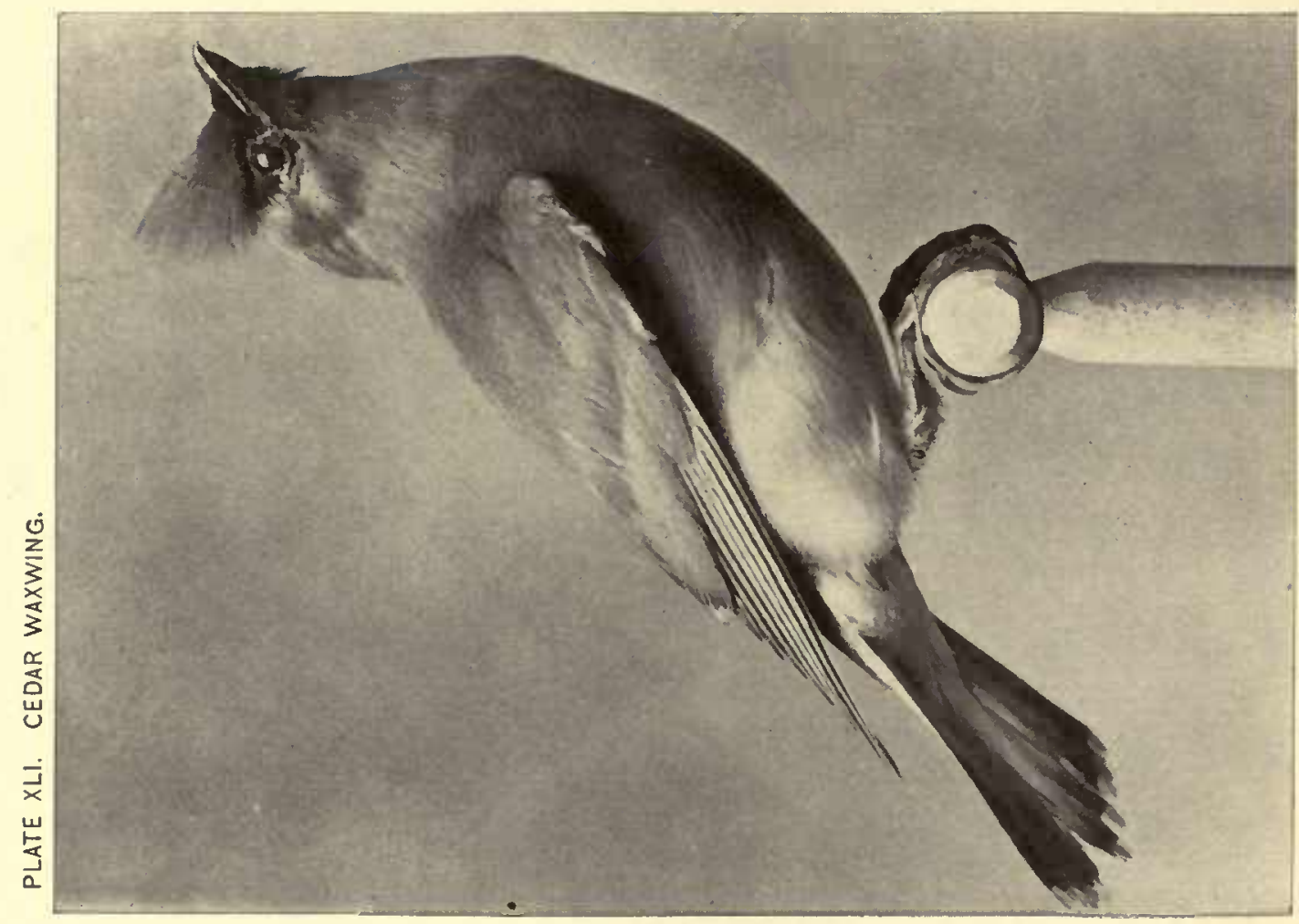




\section{PLATE XLI.-CEDAR WAXWING. CEDARBIRD.}

Ampelis cedrorum.

Head crested; forehead and sides of head black, indistinctly bordered with white; a small white streak under the eye, and a larger one on the lower cheek commencing under the base of the bill : crest and back of head cinnamon, shading lighter along the back to the rump where it is ash; chin black shading into cinnamon on breast, that into yellow on belly, and that into white under the tail; wings dark with red; horny tips on some of the quills; tail dark, square, with a yellow terminal band and (sometimes) with red, horny tips; bill and legs dark. Length, 7.15 inches.

"It wanders about," says Dr. Coues, "according to food supply ; winters in most of the United States." It nests in trees late in the season ; remains in flocks, except while breeding. Its note is a feeble peep. 
PLATE XLII. NORTHERN SHRIKE.

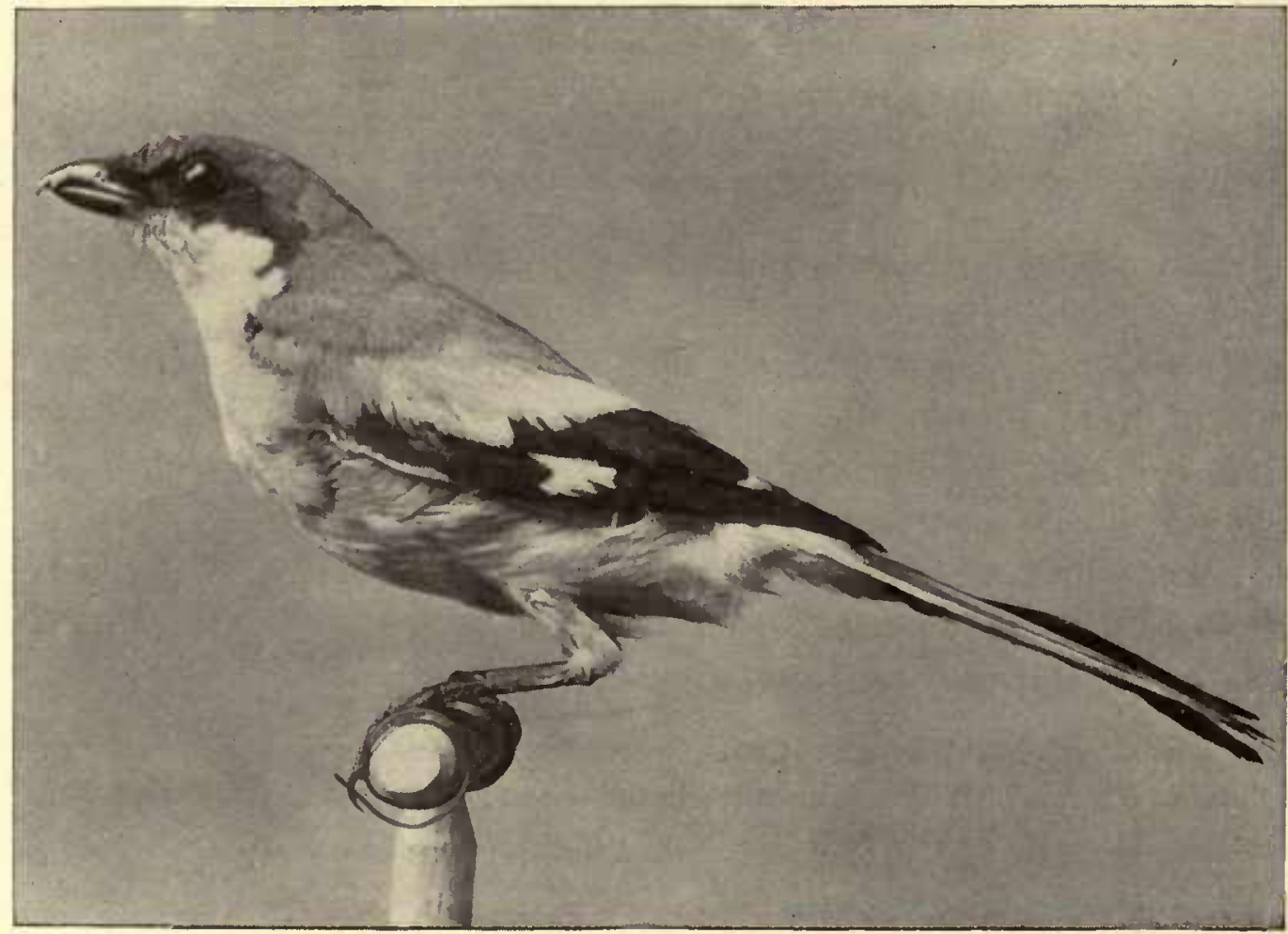




\section{PLATE XLII.-NORTHERN SHRIKE. BUTCHER-BIRD.}

Lanius borealis.

Above light bluish-gray shading to still lighter on the rump; beneath white, crossed with dark, wavy lines; sides of head hoary white, with a black stripe passing through and behind the eye; wings and tail black, the former with a white patch and some white tippings, the latter much rounded, and edged and broadly tipped with white; bill and feet dark. Length, 10 inches.

The Shrike is usually seen here from November to April. Truly a bird of prey, though not classed as such by ornithologists. Besides insects, it captures small birds and even animals, which it devours. It has a curious habit, from which it derives its name, Butcherbird, of impaling the creatures which it has seized upon thorns, as a butcher would hang up a carcass.

The observer who is fortunate enough to have witnessed the Shrike thus slaughtering its victim, has probably condemned the bird as a monster of needless cruelty. But in this 
judgment he is wrong. Wallace, in his Darwinism, hals shown that the death occasioned by creatures of prey is probably a painless one. Several cases are cited to prove this ; among them the well-known instance of Livingstone, who thus describes his sensations when seized by a lion: "He caught my shoulder as he sprang ** he shook me as a terrier-dog does a rat. The shock produced a stupor similar to that which seems to be felt by a mouse after the first shake of the cat. It causes a sense of dreaminess in which there was no sense of pain or feeling of terror, though I was quite conscious."

If, therefore, we may conclude that the Shrike's methods of obtaining food entail the least possible amount of suffering, we must at least acquit the bird of the charge of cruelty. But we may go farther than this and claim for the Shrike, and for all birds and animals of prey, that they actually confer al benefit upon the species, the individuals of which they kill. The victims which they seize and put to death are the least active and are generally those which are diseased. The vigorous and healthy escape, and since these perpetuate the race, increased vigor and health in the offspring result.

John Watson, an English writer on game-birds, has shown that by the trapping and extermination of Eagles, Hawks, Owls, Weasels, etc., sportsmen interfere with the balance of power among wild creatures, and destroy the very agents appointed to keep the moors healthful. As the Otter takes the Salmon blinded by fungoid disease, so Hawks and the like capture the slowest of the Grouse. Now the slowest Grouse is such by reason of 
weakness or disease, and since the Grouse-disease is infectious, one such bird allowed at large may taint a whole covey.

The substance of this reasoning is implied by Darwin himself in the concluding sentence of his chapter on the struggle for existence: "When we reflect on this struggle, we may console ourselves with the full belief that the war of nature is not incessant, that no fear is felt, that death is generally prompt, and that the vigorous, the healthy, and the happy survive and multiply."

\section{YELLOW-THROATED VIREO. YELLOW-THROATED GREENLET. \\ Vireo flavifrons.}

Above olive-green, brightest on the head and shading to blue-gray on the rump; sides of neck and of breast olive-green; throat and centre of breast yellow; belly white; forehead yellow and a ring of yellow encircling the eye; wings brown with two white bands, and many of 
PLATE XLIII. RED EYED VIREO.

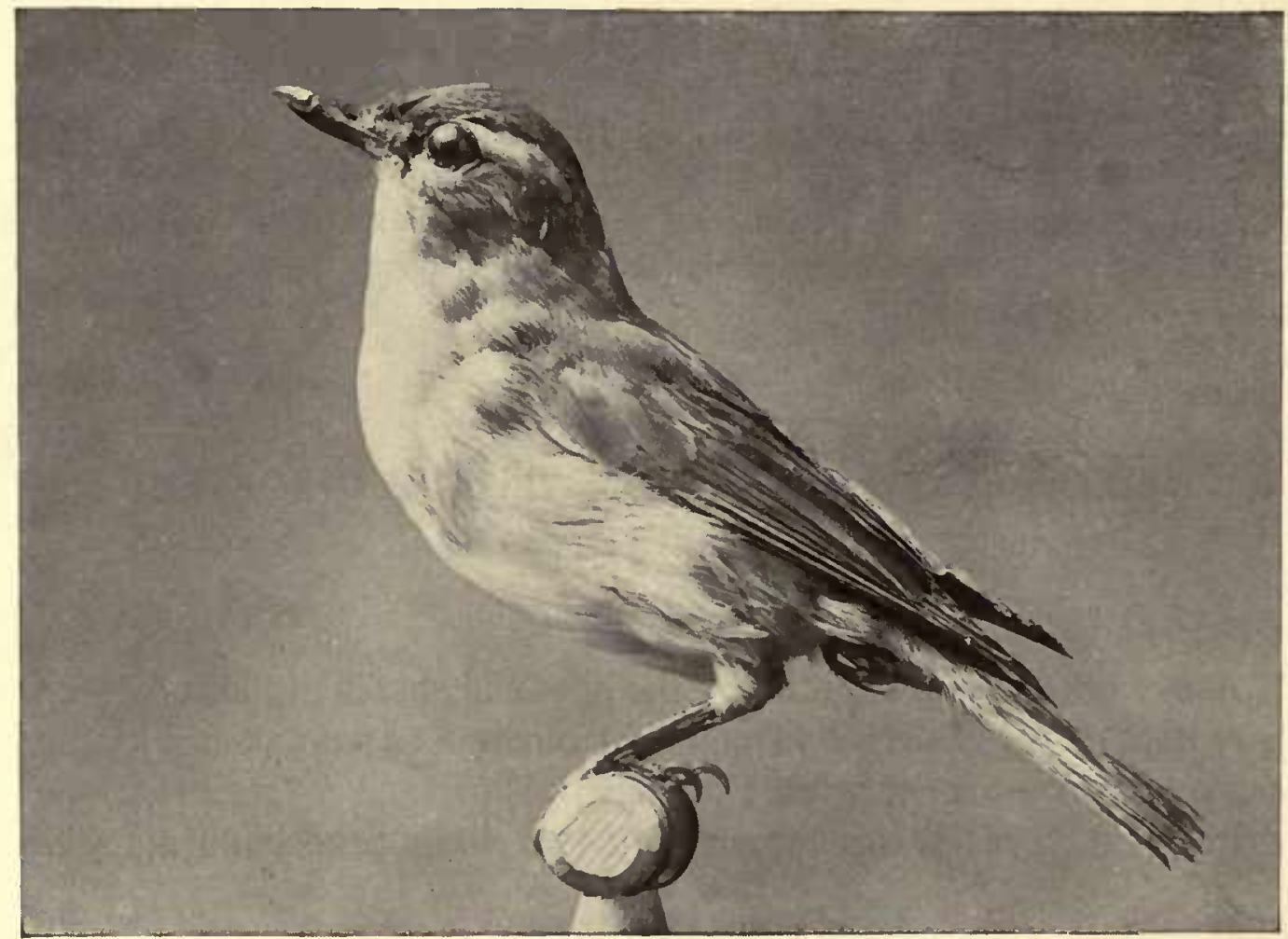


the feathers light-edged; tail short, square, brown, many of the quills light-edged; bill and feet lead-color. Length, 5.95 inches.

Migratory. Arrives early in May, leaves late in September. Nests rather low in trees, chiefly in woods or orchards. A beautiful bird and an accomplished vocalist.

\section{PLATE XLIII.-RED-EYED VIREO. RED-EYED GREENLET. \\ Vireo olivaceus.}

Above light olive-green; crown ash edged with darker; a white streak passes through and beyond the eye; cheeks pale green; throat and breast yellowish; belly white tinged on sides with yellow, and terminating under the rump in light yellow; tail short, nearly even, brown, the quills edged with greenish; lower mandible lighter than the upper one; wings long, in color like the tail; feet lead-color ; eyes red. Length, 6.20 inches.

Migratory. Arrives middle of May, leaves early in October. Its nest is pensile and is attached to the branch of a tree, usually in woods. A sweet singer. 
PLATE XLIV. SOLITARY VIREO.

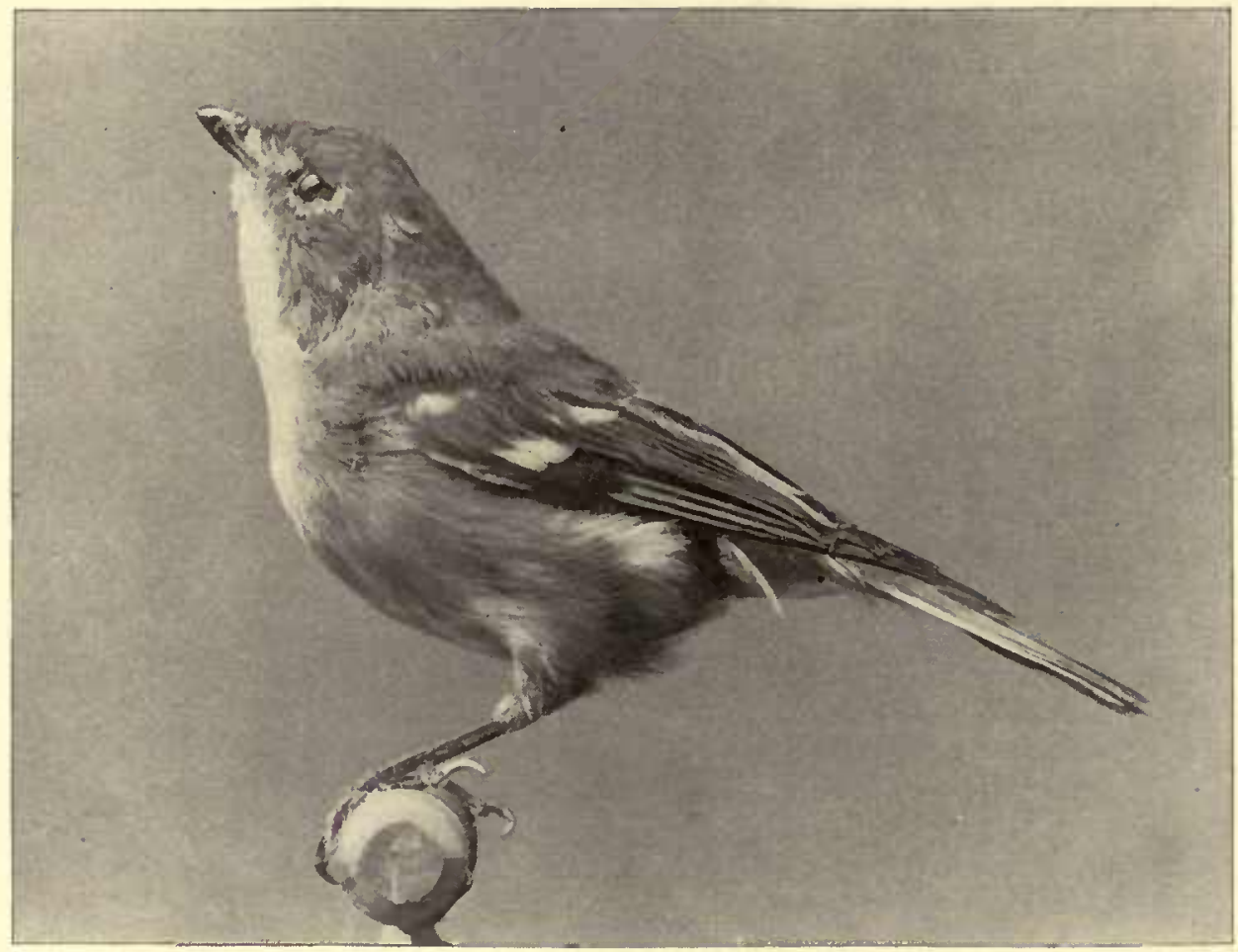




\section{PLATE XLIV.-BLUE-HEADED VIREO (OR GREENLET). SOLI- TARY VIREO (OR GREENLET.)}

Vireo solitarius.

Above olive-green; head and cheeks blue-gray; a white line from the nostrils to the eye and encircling it; breast pale ash; belly white; wings dark, with two white bars and many of the feathers edged with white ; tail short, square, dark, the outermost feathers edged with white ; bill and feet dark. Length, 5.60 inches.

Migratory. Arrives early in May, leaves early in October. Nests in bushes or low trees. Like all of the Vireos, it is fearless and confiding towards man.

Bradford Torrey relates an incident illustrative of this docility. He once found a Solitary's nest, the female sitting at the time upon her eggs, and was allowed to approach until he almost touched the bird. He made daily visits, bringing food, until finally the little creature became so tame as to eat insects and other dainties from his hand, allowing him mean while gently to smooth her feathers.

The Solitary Vireo is not a rare bird though it is less common than the Red-eyed, the 
PLATE XLV. WHITE.EYED VIREO.

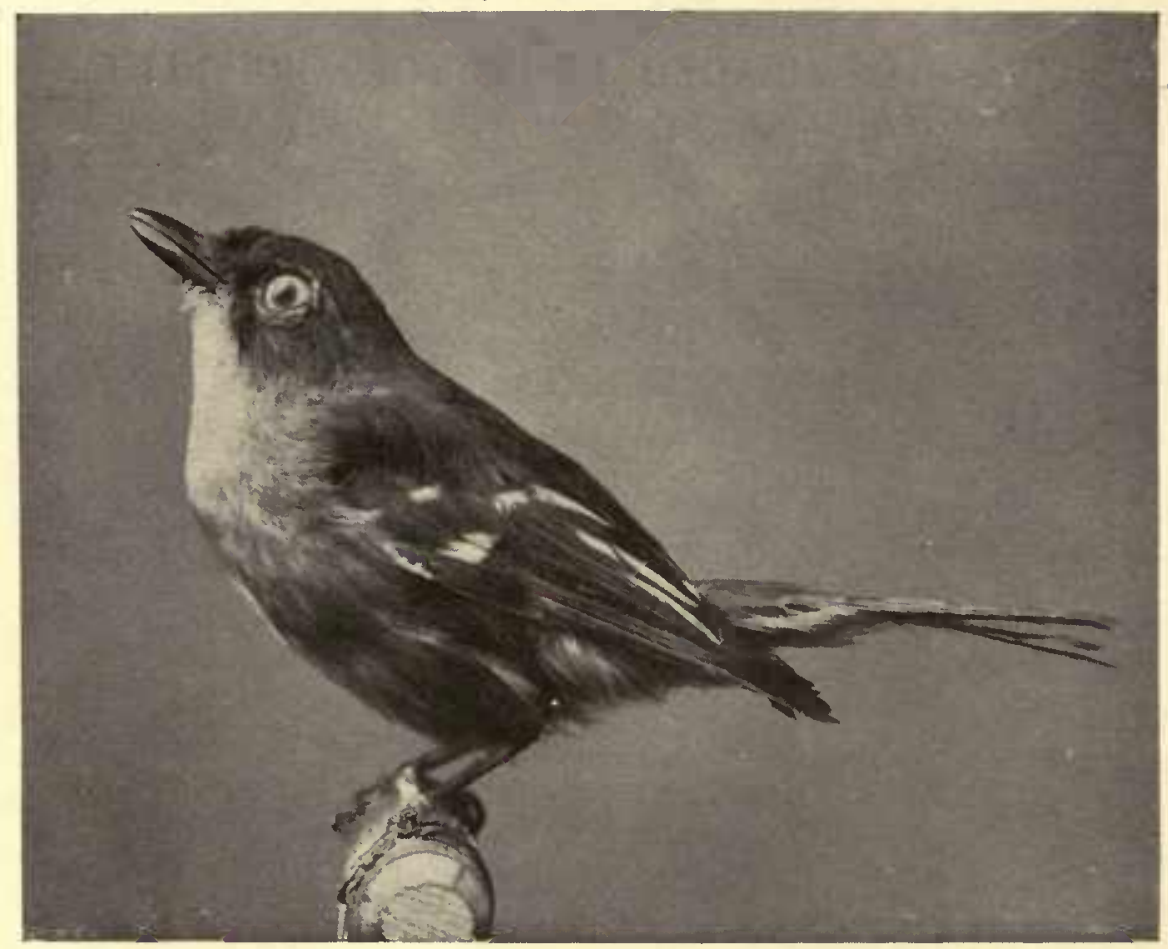


Yellow-throated or the White-eyed. Probably the majority of the species nest farther north than this locality; for on their first arrival, about May 1, and again, as they go south in September, they are quite numerous, while during the actual breeding season, they are less plentiful.

\section{PLATE XLV.-WHITE-EYED VIREO. WHITE-EYED GREENLET.}

Vireo noveboracensis.

Above olive-green; a yellow line from the nostrils to the eye and encircling it; eyes wbite; breast and belly dull white; sides of body yellow; wings dusky, with two light bands, some of the feathers lightedged; tail dusky, nearly even; bill and feet dark. Length, 5.25 inches.

Migratory. Arrives early in May, leives the middle of October. lis nest is pensile and is usually placed in a bush. A sweet and persistent singer. 
PLATE XLVI. BLACK AND WHITE WARBLER.

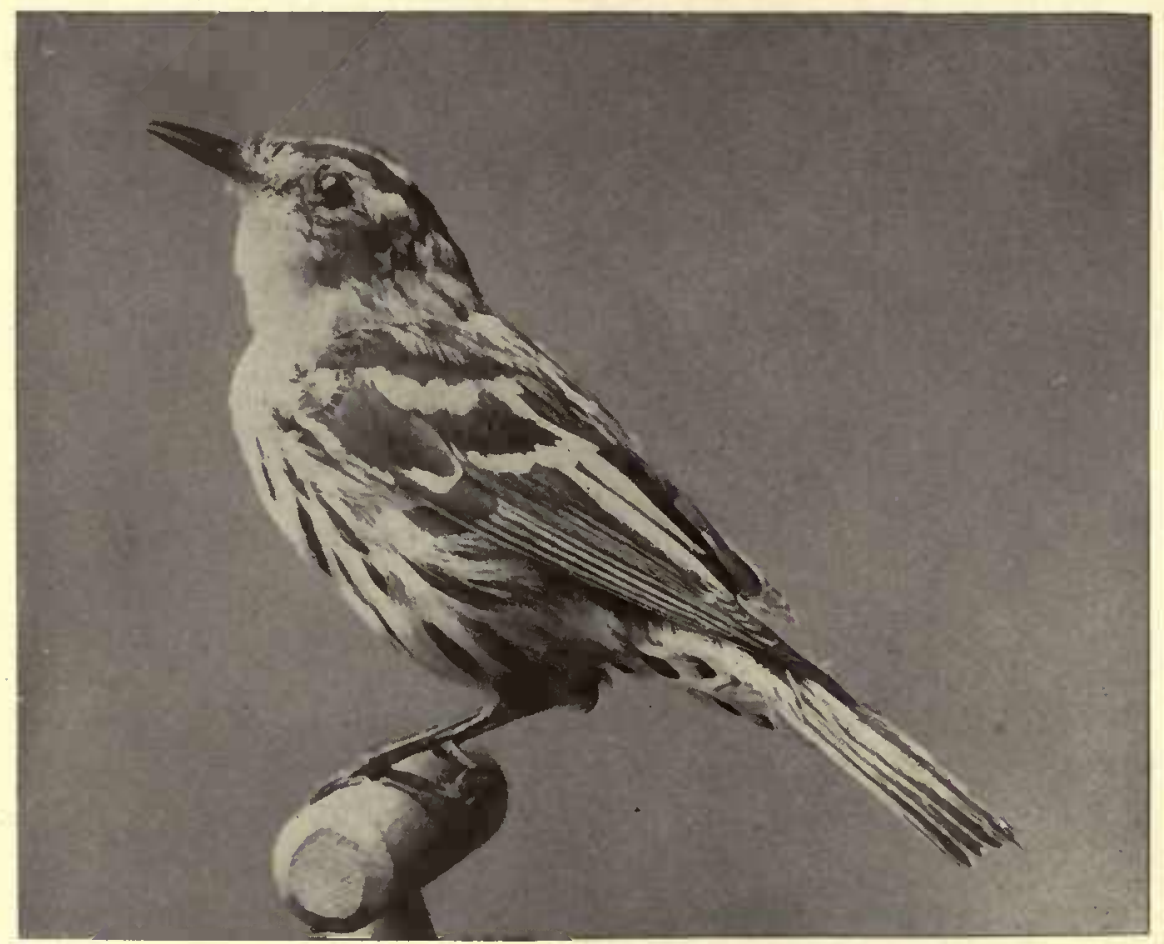




\section{PLATE XLVI.-BLACK AND WHITE WARBLER. BLACK AND WHITE CREEPER.}

\section{Mniotilta varia.}

Black above, feathers much edged with white; white stripes on the crown, through the eye, and on the cheeks; belly white with black streaks on the sides; wings black, many of the feathers edged with white, and having two white, transverse bands; tail nearly even, black with some edging and spots of white; bill and feet dark. Length, 5.30 inches.

Migratory. Arrives May 1, leaves early in October. Its nest is placed on the ground; often near the root of a stump or tree.

Dr. Coues writes: "A common bird of woodland, thicket and swamp, generally seen scrambling actively about the trunks and larger branches of trees, rather like a Nuthatch than like a Creeper, the tail not being used as a prop."

A poor singer. 


\section{WORM-EATING WARBLER.}

\section{Helmitherus vermiverus.}

Above olive-green; beneath buff, paler almost to whiteness on the belly; head all round buff with two black stripes on the crown extending from the bill to the nape, and a similar though narrower stripe through the eye; wings and tail olive-green, the latter rounded; bill and feet pale. Length, 4.85 inches.

Migratory. Arrives about the middle of May, leaves late in September. It nests on the ground and is usually seen on the ground or near it. Sometimes, however, quitting its scratching among the leaves, it will scramble up and down the tree-trunks hunting in a somewhat listless manner for insects and spiders. A shy, inactive bird, not very handsome, a feeble singer and burdened with a name disagreeable in its suggestions. 


\section{PARULA WARBLER. BLUE YELLOW-BACKED WARBLER.}

\section{Compsothlypis americana.}

Above light-blue, with a patch of yellow in centre of the back; chin and throat yellow; breast yellow, spotted with brown; belly dull white; wings brown, with two light bands, some of the feathers edged with blue; tail brown, some of the feathers edged with blue, and the outer ones spotted near the tips with white; upper mandible dark, lower one lighter; legs pale. Length, 4.70 inches.

- Migratory. Arrives middle of May, leaves early in October. Nests in trees. It is not easy to examine this bird, since it not only usually keeps to lofty situations in the tree, but it is exasperatingly restless and active ; at least so will say the observer who, with operalglass to eye, strives to watch it as it clambers and flutters among the branches and foliage. The best periods for observation are during migration; for, in common with many Warblers, and some other birds as well, the majority of this species breed farther north.

The bird student will not have prosecuted his researches for a long period without remarking a fact concerning the migrations of the Warblers which will give a pleasurable 
interest to his rambles. He will find that, though to-day none of them are visible, tomorrow the trees and bushes may swarm with the active little creatures, while on the next day, perhaps, all will have departed. It is this element of uncertainty as to what a walk will disclose that fascinates the observer, and tempts him into the woods and fields even upon unpromising days and in the most inclement weather.

The Parula Warbler is a trim, graceful little bird, but a poor singer.

\section{YELLOW WARBLER. SUMMER YELLOWBIRD.}

Dendroica astiva.

Above greenish-yellow; crown and under-parts golden, streaked with reddish-brown; wings and tail dusky, most of the feathers edged with yellow (tail nearly square); bill brown; feet paler. Length, 5.10 inches.

Migratory. Arrives early in May, leaves early in September. Orchards and gardens furnish the conditions it prefers for a nesting site.

- Flight undulatory ; song pleasing but unimportant.

"This species is remarkable," writes DeKay, "for its instinctive sagacity in getting 
rid of the eggs of the Cowbird. As the egg is too large to be thrust out, the Yellow Warbier commences a new nest above it. In one instance such reconstruction was twice effected ; thus forming a nest of three stories."

The clever method taken by the Yellow Warbler to baffle its persecutor indicates intelligence of a comparatively high order, since most birds are easily imposed upon and hatch and tend the greedy interloper to the ultimate destruction of their own offspring. The young Cowbird, once established, is able, by reason of its superior size and strength, not only to appropriate most of the food brought by its foster parents, but entirely to dispossess its luckless companions by crowding them out of the nest, when, falling to the ground, they perish miserably. 


\section{MYRTLE WARBLER. YELLOW-RUMPED WARBLER. MYRTLEBIRD.}

Dendroica coronata.

Above slaty-blue streaked with black; below white, except the upper-breast and sides of body which are black; crown, rump and a spot on eacb side of the breast yellow; sides of head black, with a light streak over the eye; wings brown, with two light bands; tail brown, slightly notched, and somewhat spotted with white; bill and feet dark. Length, 5.65 inches.

Migratory. Passes to the north in April and May, and again southward, in September. At these times, for shoit periods, it is rather abundant.

Different individuals are varied in their markings, but the four yellow spots on crown, rump and sides of breast are constant, and afford means of confident identification. 


\section{BLACKBURNIAN WARBLER.}

\section{Dendroica blackburnia.}

Black above including wings and tail, but with an orange stripe on crown, a white patch on wings and a light stripe on back; neck, upperbreast, and sides of head, bright orange-except a black streak through the eye widening from the bill backwards (in this black streak, under the eye, is a small orange crescent); lower-breast lighter orange (or yellow) shading to white on the belly; sides of body striped with black and white; tail nearly even, with much white on outer feathers; bill and feet dark. Length, 5.25 inches.

Migratory. A shy bird inhabiting tall trees with dense foliage, and consequently not often seen nor easily studied. A single glimpse of its uncommon beauty, however, will fully repay the labor of much arduous search. Its times of migration are May, northward, and September, southward. It is then abundant, though, as intimated, a sharp eye, and some perseverance are required to detect it. 
PLATE XViI. BLACK.THROATED BLUE WARBLER. 


\section{PLATE XLVII.-BLACK-THROATED BL.UE WARBLER.}

\section{Dendroica carulescens.}

Above gray-blue; sides of head, throat and sides of body black; breast and belly white; wings dark, with a white patch, and some of the feathers edged with blue; tail dark, nearly even, some of its feathers bordered on the outer edge with blue, and patched on some of the inner webs with white; bill black; feet brown. Length, 5.25 inches.

Migratory. Arrives early in May, leaves early in October. Nests in bushes. Most abundant during the migrations.

The following extracts from Mr. Burroughs admirably characterize the song and habits of this Warbler:

Song: "twea-twea-tweaee in the upward slide, and with the peculiar $z$-ing of Summer insects, but not destitute of a certain plaintive cadence. It is one of the most languid, unhurried sounds in all the woods. I feel like reclining upon the dry leaves at once. Audubon says he has never heard his love-song ; but this is all the love-song he has."

Habits: "He has a preference for dense woods of beech and maple, moves slowly amid the lower branches and smaller growths, keeping from eight to ten feet from the ground, and repeating now and then his listless, indolent strain." 
PLATE XLVIII. MAGNOLIA WARBLER,

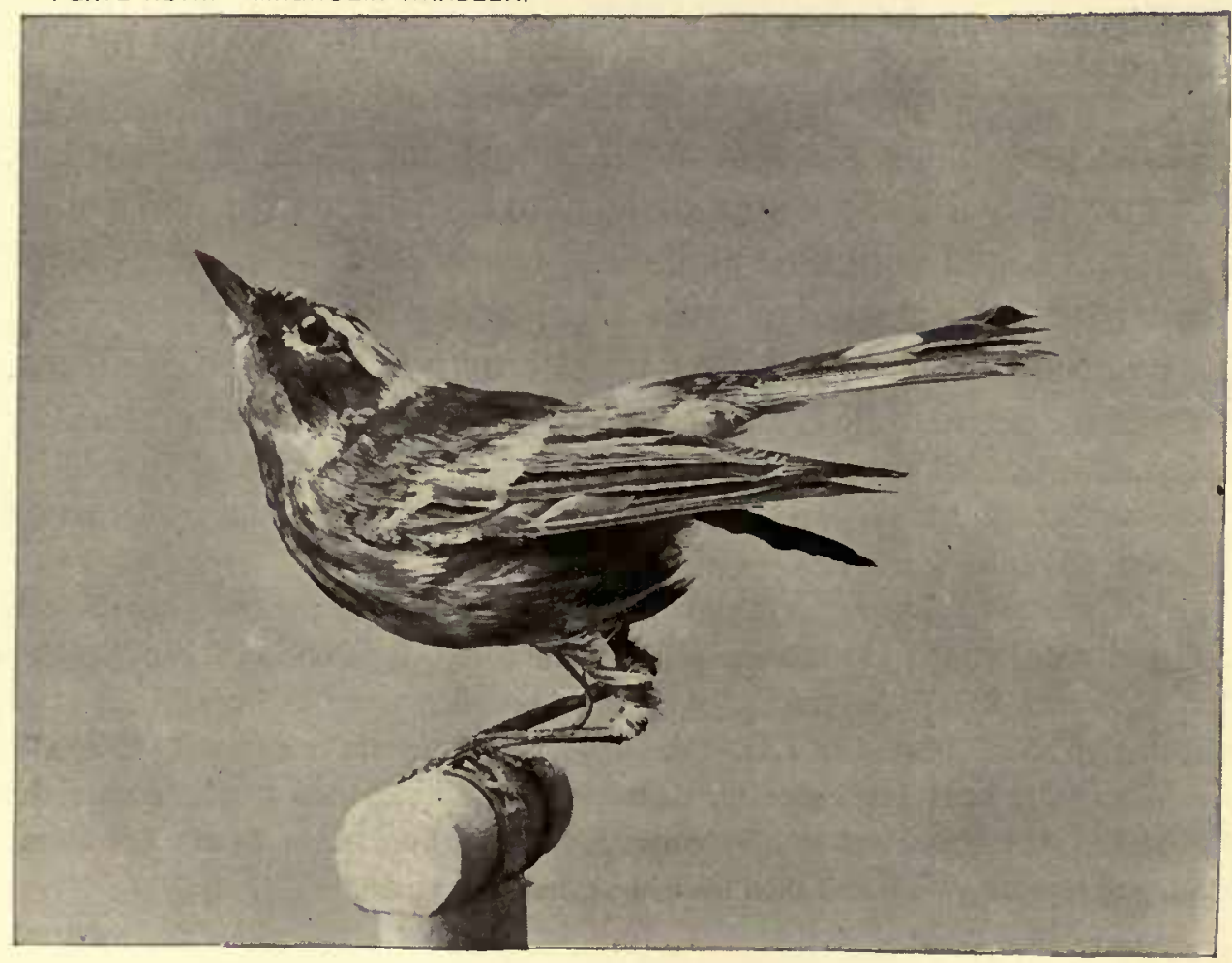




\section{PLATE XLVIII.-BLACK AND YELLOW WARBLER. MAGNOLIA WARBLER.}

\section{Dendroica maculosa.}

Crown ash; back black; rump yellow; a white stripe commences over the eye and extends backward to the neck; chin and throat yellow; breast yellow, but crossed and bordered by lateral black streaks which also extend along the sides of the body; wings dark with a white patch, and many of the feathers pale-edged; tail dark and rounded, with white patches on the inner web of all the feathers except the middle pair ; bill and feet dark. Length, 5.10 inches.

Migratory. A sharp and constant watch will be necessary to insure a sight of this little beauty in Spring, for he does not at that time give us more than a week or ten days of his company as he hastens northward. In the Fall he tarries longer, coming to us about the middle of September and continuing his journey rather early in October. Dr. Mearns says: "This beautiful species is partial to the hemlock-trees, where it feeds in company with the Black-throated Green Warbler; but it is found in all kinds of woods.

"It frequently descends to the ground ; sometimes inhabits low bushes." 
PLATE XLIX. CHESTNUT-SIDED WARBLER.

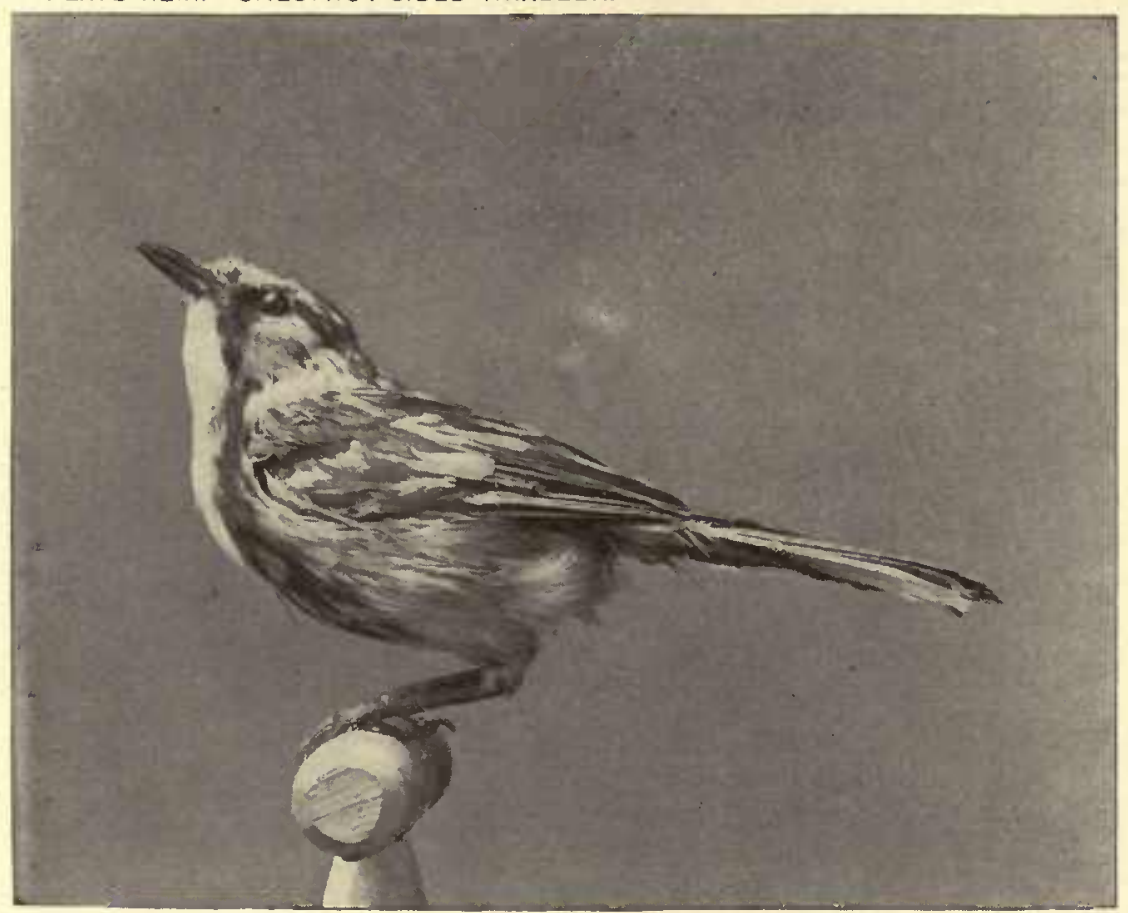




\section{PLATE XLIX.-CHESTNUT-SIDED WARBLER.}

\section{Dendroica pensylvanica.}

Back streaked with black and greenish-yellow; a cbestnnt stripe on sides of body; crown yellow enclosed in white, and that in black; sides of head and entire under-parts white, but the white of the cheek and throat is cut by a black streak which runs from base of bill to the beginning of the chestnut side-stripe; wings brown, with two indistinct bands, and some of the feathers edged with yellow; tail brown, nearly square, and somewhat spotted and streaked with white; bill dark; feet pale. Length, 5.10 inches.

Migratory. Arrives early in May, leaves late in September. Nests in bushes and small trees. Note monotonous and uninteresting. 
PLATE L. BAY.BREASTED WARBLER.

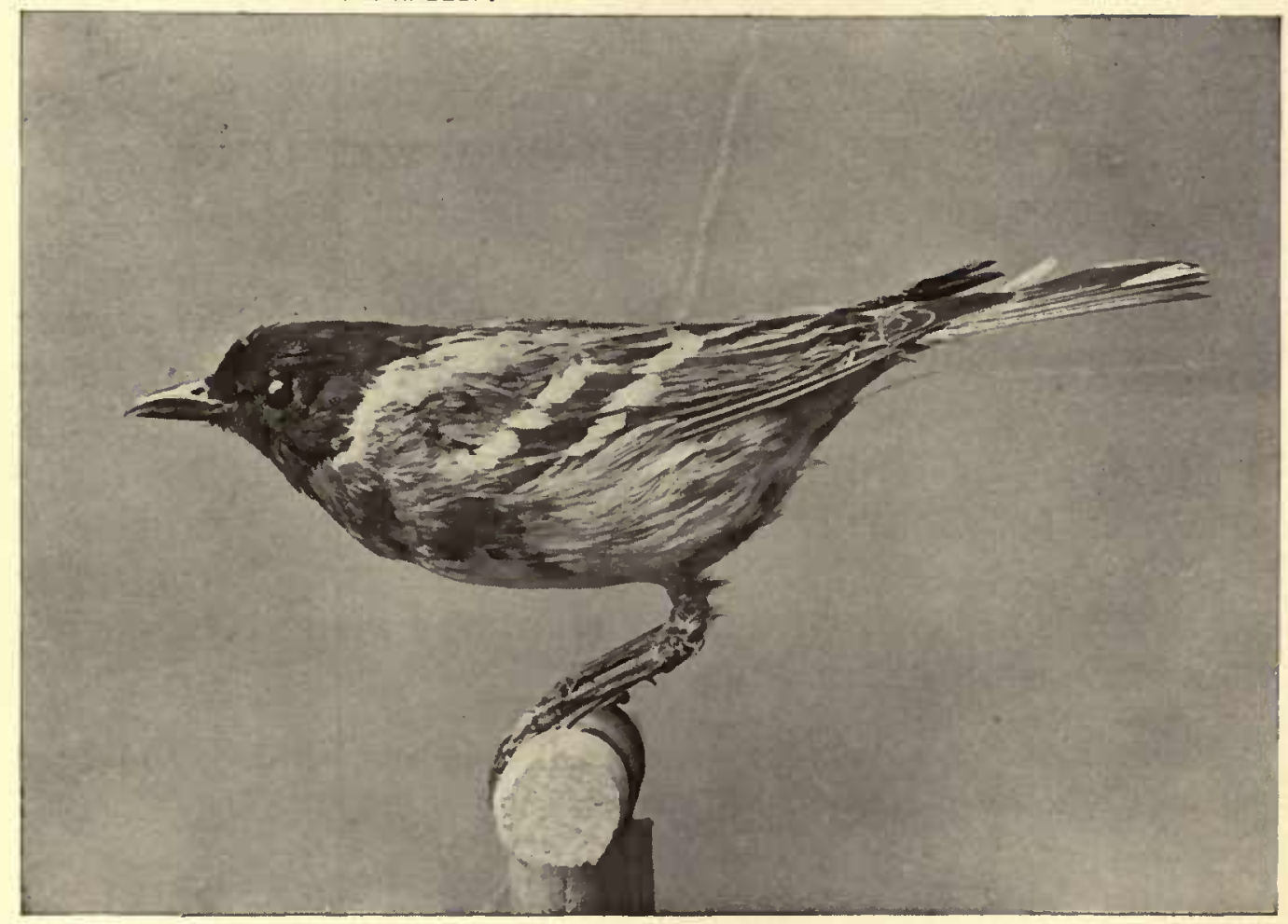




\section{PLATE L.-BAY-BREASTED WARBLER.}

\section{Dendroica castanea.}

Above slate streaked with black; throat and sides chestnut; centre of breast and belly reddish-white; crown,chestnut; forehead and cheeks black; a buff patch on each side of the neck; wings dark brown with two white bars; tail dark brown with some white blotches ; bill and feet dark. Length, 5.60 inches.

Migratory. Seen passing northward the latter half of May, and returning to the south late in September. Dr. Mearns says: "Its habits are very similar to those of the Black-poll. It is usually seen in the tree-tops, where its movements are rather heavy and slow. It seems to be especially fond of bathing in the brooks." Its song is cheerful but simple. 
PLATE LI. BLACK-POLL WARBLER.

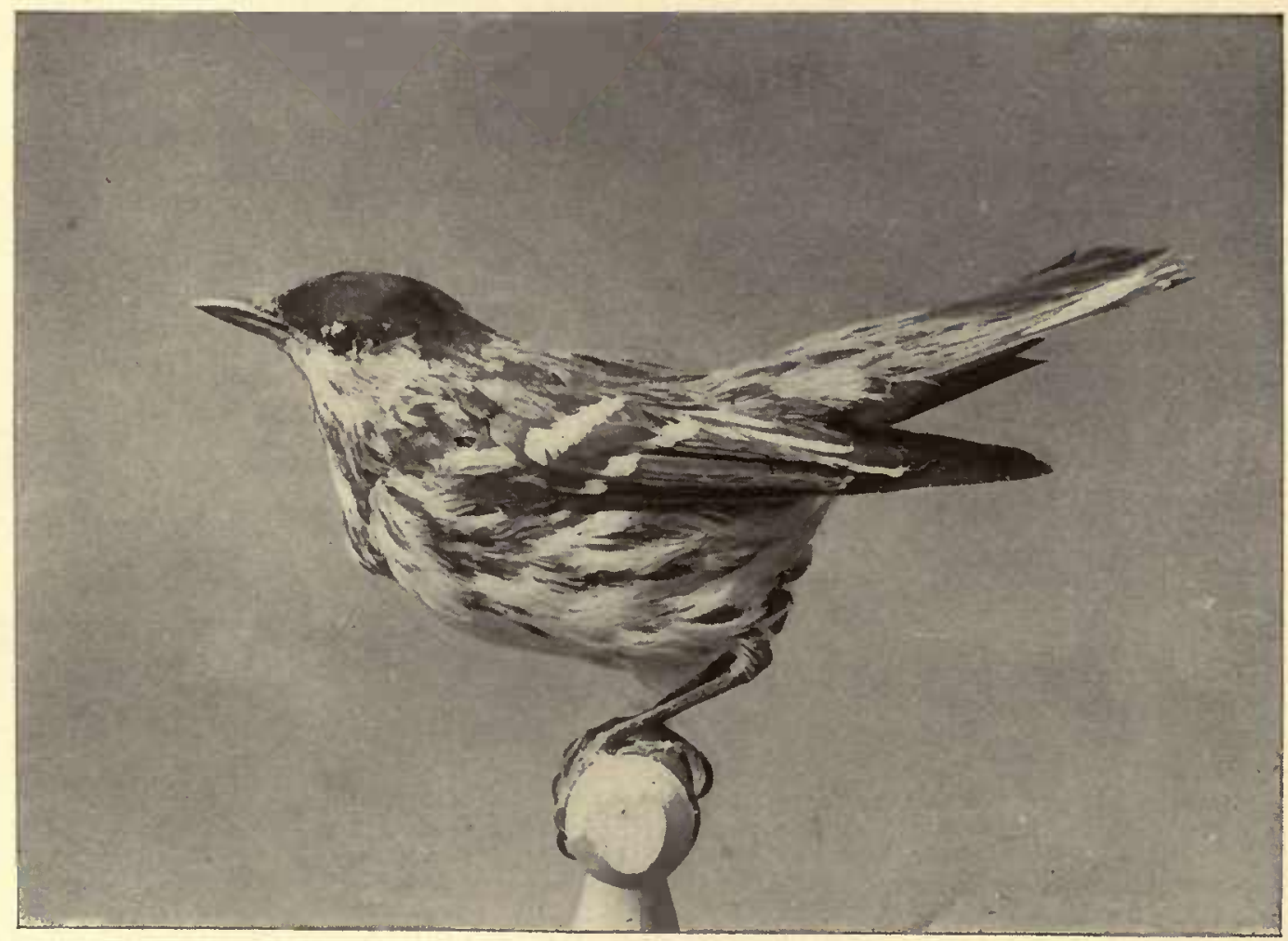




\section{PLATE LI.-BLACK-POL.L WARBI.ER.}

\section{Dendroica striata.}

Head black streaked with brown ; back dark ash streaked with black; cheeks white; throat, breast and belly white, but all of them streaked on the sides with black; wings brown with two light bands; tail square, brown with white spots on some of the inner webs; lower mandible lighter than the upper one; feet pale. Length 5.50 inches.

Migratory. Passes toward the north late in May, and again, southward, late in October. A brisk little fellow, but even less of a singer than most of the so-called "Warblers." Rather abundant during migration. 
PLATE LII. BLACK-THROATED GREEN WARBLER

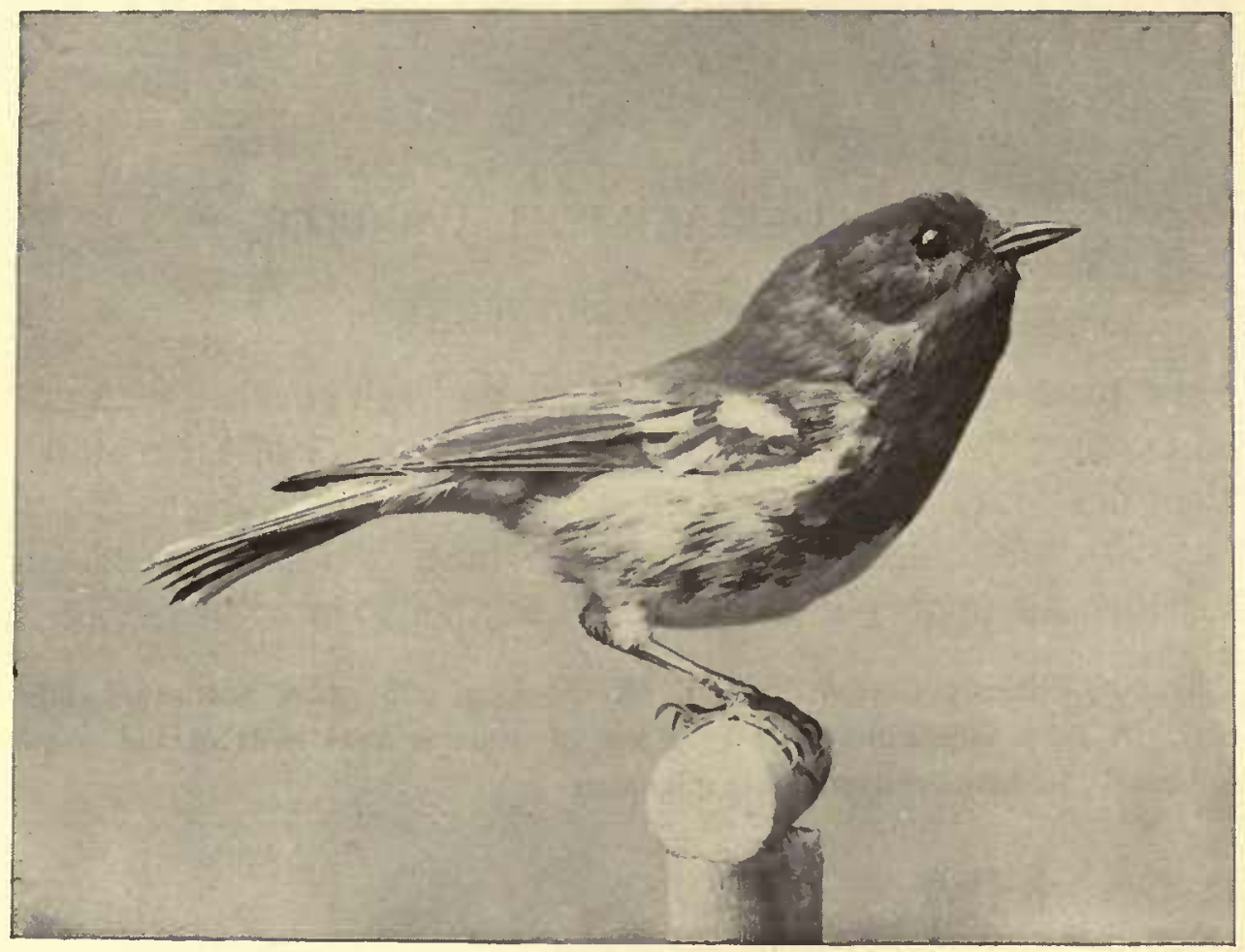




\section{PLATE L1I.-BLACK-THROATED GREEN WARBLER.}

\section{Dendroica virens.}

Back and crown light yellowish-green; forehead, a band over the eye, cheeks and sides of the neck rich yellow; chin, throat and breast black; wings brown, with two white bars, many of the feathers paleedged; tail brown; the outer three feathers almost wholly white; bill and feet dark. Length, 5.10 inches.

Migratory. Arrives May 10, leaves October 25. This Warbler, like others of its family, is most frequently observed during its migrations, when for short periods it is rather abundant. It breeds here, however, and can be seen through the whole Summer.

It seems to prefer pine or hemlock trees, and usually chooses them to nest in.

Dr. Mearns says: "It is seen in large companies, clinging to the tips of the branches, exhibiting a fluttering of wings and incessant activity. Its attitudes and notes remind one of the Titmice ; but it possesses a very pleasant song besides." 
PLATE LIII. PALM WARBLER.

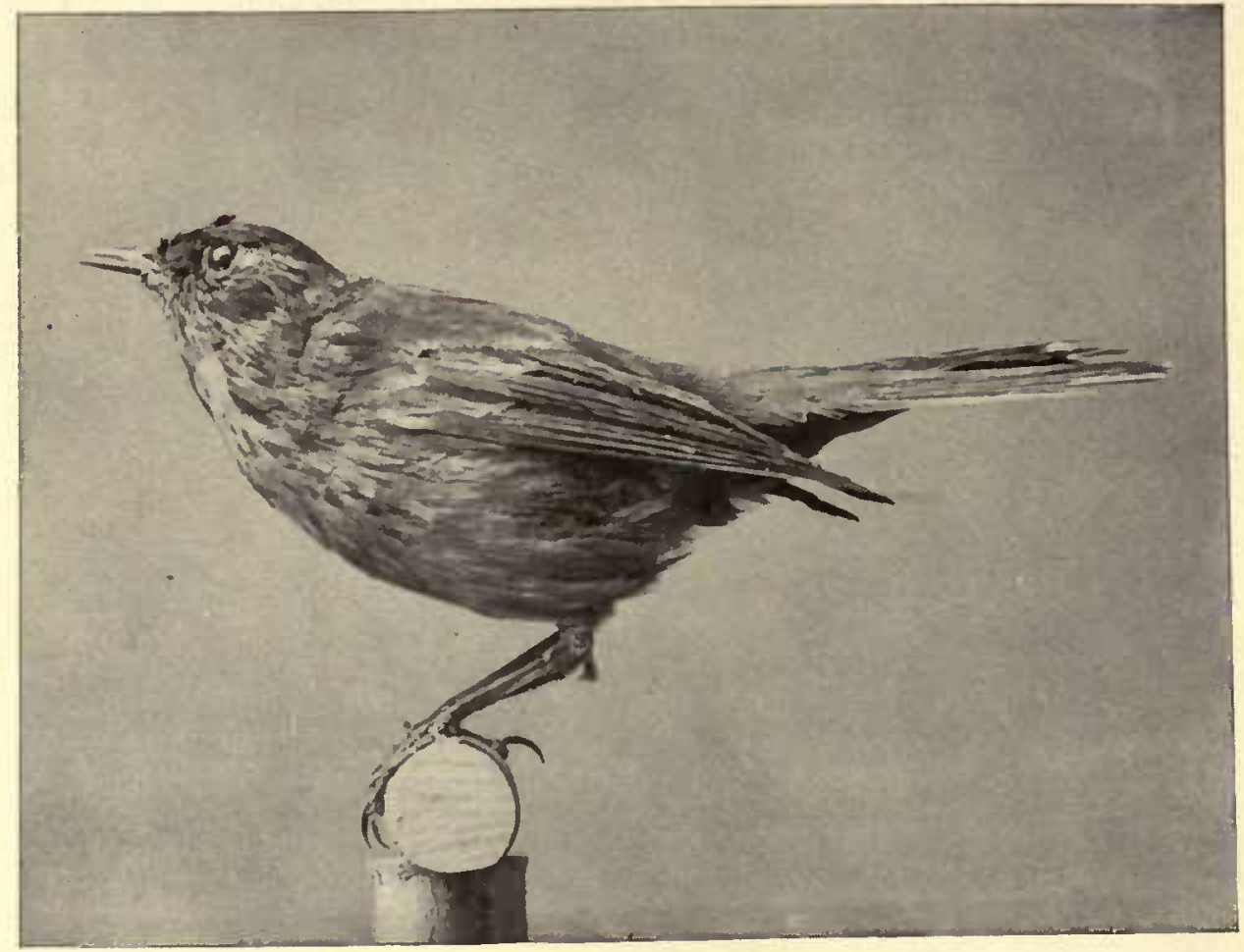




\section{PLATE LIII.-YELLOW RED-POLL WARBLER. PALM WARBLER.}

\section{Dendroica palmarum.}

Above brownish-olive, rump yellowish-green; crown dark bay; beneath yellow, streaked on the breast with bay; a bright yellow streak over, and a brownish line through the eye; the two outer tail-feathers tipped with square white spots; no white wing-bars. Length, 5.40 inches.

Migratory. One of the earliest of the Warblers to come, and one of the latest to go. Its times of migration are late in April northward, and late in September or early in October southward. We see it here only as it passes. It generally keeps to fields and road-sides, and is oftener seen hopping upon the ground and flitting among bushes than in more elevated situations. Dr. Mearns thus points out one of its notable habits: "The Red-poll's tail executes a perpetual lateral vibratory movement, which is as characteristic as is the tilting of the Wagtails; this motion is often accompanied by a feeble chip, the only note I have heard it utter." 


\section{MARYLAND YELLOW-THROAT.}

\section{Geotblypis trichas.}

Above olive-green, brownish on the head; chin, throat and upperbreast yellow; belly light buff, shaded on the sides with brown; underside of the rump yellow; a black band on the forehead passes backward through and beyond the eyes; wings brown, many of the feathers edged with light olive; tail nearly even, same color as wings; bill dark; feet pale. Length, 5.30 inches.

Migratory. Arrives early in May, leaves early in October. Nests usually upon the ground, sometimes low in thickets.

A shy bird; not given to frequent flights, and generally seen hopping about upon the ground or flitting amongst the shrubbery. Song vigorous and rich, but not varied. 


\section{YELLOW-BREASTED CHAT.}

\section{Icteria virens.}

Above uniform olive-green; throat, breast and lining of wings yellow ; belly white, tinged on sides with brown; a white stripe over, and a white patch under the eye; tail nearly even; bill black; feet brown. Length, 7.50 inches.

Migratory. Arrives early in May, leaves early in September. Nests in bushes. A shy bird, odd and uncouth in its motions and with an extraordinary song, which Nuttall thus rather fancifully describes: "Some of these notes resemble the whistling of the wings of a flying duck, at first loud and rapid, then sinking till they seem to end in single notes. Other tones are now heard like the barking of young puppies, with a variety of hollow, guttural, uncommon sounds, and terminated occasionally by something like the mewing of a cat." The song is frequently heard moonlight nights.

The Chat is noted for its ventriloquial powers. This art it employs with good success in luring enemies from its nest.

Dr. Mearns, writing of one of "its ridiculous performances," says : "It has the habit of flying up in the air, with its legs dangling, then allowing itself to drop nearly to the ground." 
PLATE LIV. OVEN.BIRD.

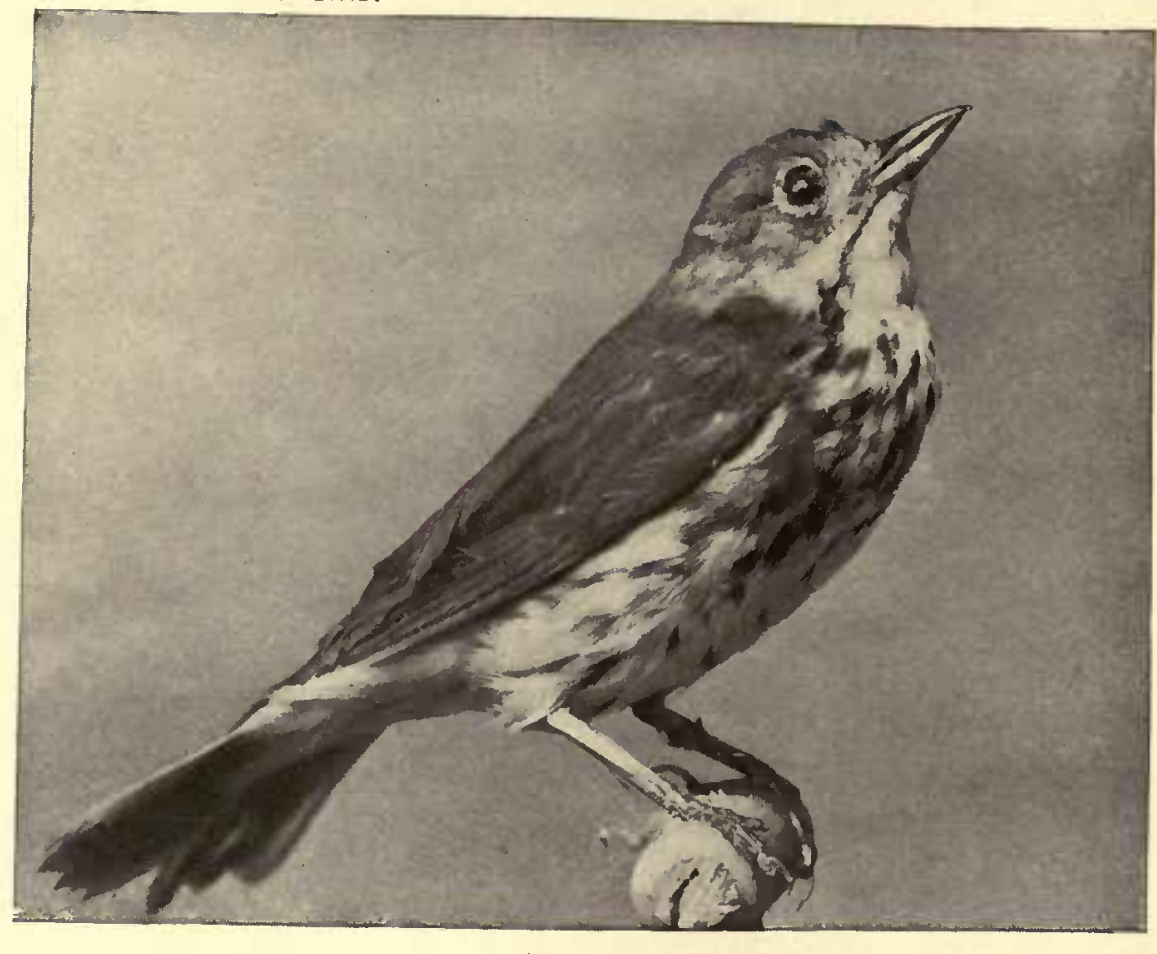




\section{PLATE LIV. -OVEN-BIRD. GOLDEN-CROWNED THRUSH.}

Seiurus aurocapillus.

Upper-parts, including wings and tail, uniform olive-green ; crown with two lateral stripes of black inclosing a wider stripe of brownishorange; a pale ring around the eye; underneath white with black spots and streaks on breast and sides; tail nearly even; bill and feet pale. Length, 6.15 inches.

Migratory. Arrives early in May, leaves late in October. Its nest is built on the ground and is roofed with leaves and grass resembling a "Dutch-oven" in shape, hence the popular name Oven-bird.

The song has been likened to the syllables quicba-quicha-quicha repeated rapidly and often. It is begun softly, and grows continuously louder with an even crescendo.

There is another song indeed, less often uttered, more elaborate than the ordinary performance; Dr. Coues calls it a "luxurious, nuptial song." The bird is a walker. 


\section{HOODED WARBLER.}

\section{Sylviana mitrata.}

Above olive-yellow ; forehead, cheeks, breast and belly bright yellow; crown, chin and neck all round jet black; wings and tail brown, the latter spotted on the three outer feathers near the tip with white; bill black; feet pale. Length, 5.65 inches.

Migratory. Arrives early in May, leaves early in September. A rather abundant bird, lovely in plumage, and a charming singer. It must be sought in remote spots, since it loves dense woods whose shelter it seldom abandons. It nests in low situations. 


\section{AMERICAN REDSTART. REDSTART.}

Setophaga ruticilla.

Head, neck, back and middle-breast blue-black; sides of breast orange; belly white; wings with an orange band and lined with orange ; tail slightly rounded, black, broadly patched on each side near the base with orange; bill and feet black. Length, 5.40 inches.

Migratory. Arrives early in May, leaves late in September. Nests on small trees in woods or meadows. A rather shy bird, with a sweet but monotonous song. 
PLATE LV. CATBIRD.

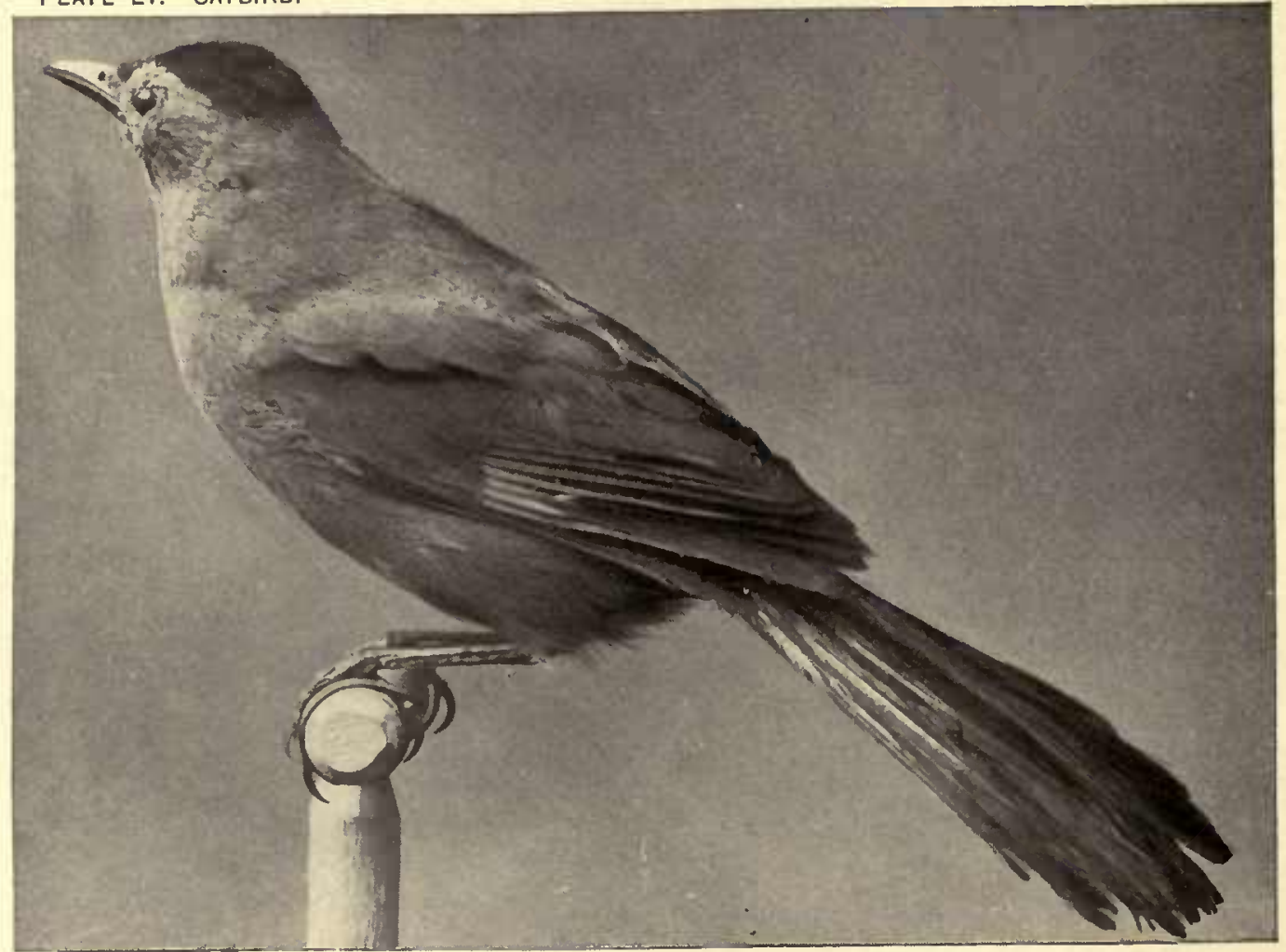




\section{PLATE LV.-CATBIRD.}

Galeoscoptes carolinensis.

Prevailing color slate, palest below; under-side of rump reddish; crown, tail, bill and feet black; tail full and rounded. Length, 8.90 inches.

Migratory. Arrives early in May, leaves about October 15. Nests in bushes. A common bird, lurking in the shrubbery of gardens or in the tangle of roald-side thickets, and uttering its well-known cat-like mew with a persistency worthy of a more agreeable sound. Another of its calls, even still less musical, resembles the syllables trat-tat-tat-tat given in quick succession.

It has, however, a beautiful song which has been called a medley, imitative of the Robin and the Thrush. This song is heard only during the breeding season, and though truly an admirable performance, a quick ear may detect in it a slight, whining quality suggestive of the feline note.

The bird is really a handsome one, but, owing to its skulking habits, and the unsocial manner with which it resents inspection, scarcely a favorite. 


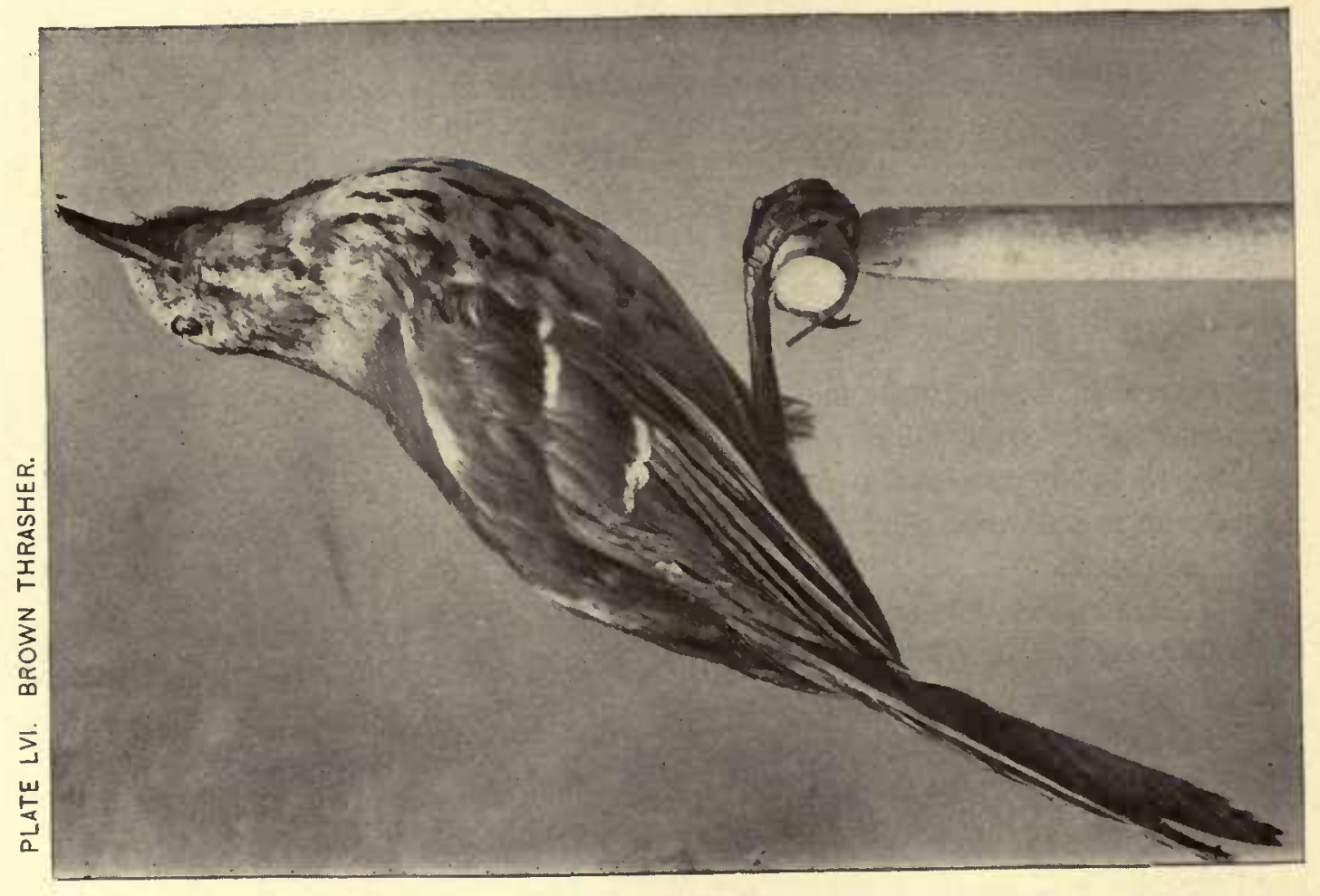




\section{PLATE LVI.-BROWN THRASHER. BROWN THRUSH.}

Harporbyncus rufus.

Above light reddish-brown; throat, middle of belly and underrump white-but, inclosing the throat, and on breast and flanks much spotted with brown; two white bars on wings ; tail long and rounded; bill dark; feet pale; iris yellow. Length, 11.40 inches.

Migratory. Arrives late in April, leaves early in October. Nests in bushes or on the ground. A gifted vocalist, scarcely surpassed either in sweetness or variety by any other bird. During the nesting season it is said to sing at night. The Brown Thrasher remains for the most part in the cover of thickets in whose recesses he has his nest, but when the singing frenzy is on him he may be seen on the top of some rather low tree pouring forth his melody.

When the sun illumines his brown coat, the tint of red in it is strikingly apparent. 
PLATE LVII. WINTER WREN.

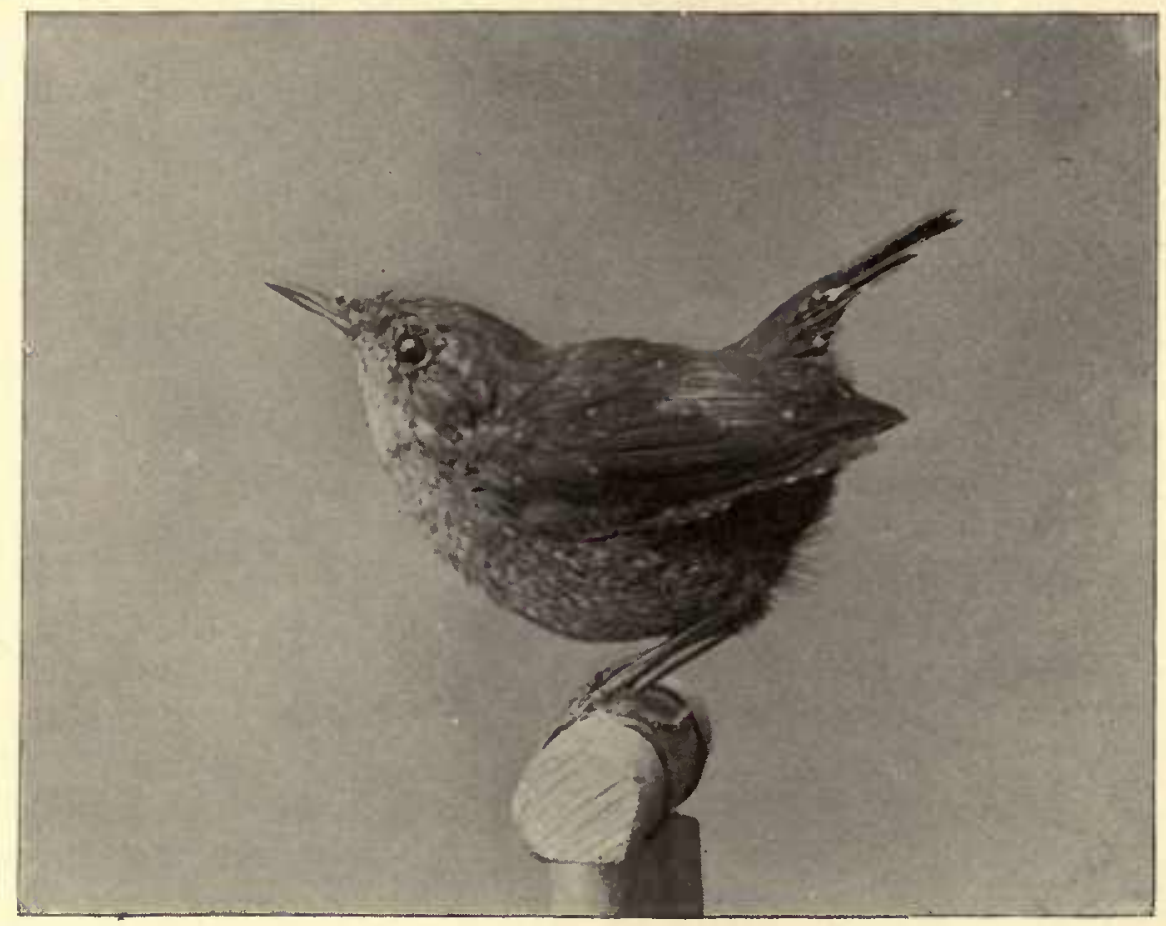




\section{PLATE LVII.-WINTER WREN.}

Troglodytes biemalis.

Reddish-brown all over, darker on the back; barred and spotted everywhere except on head and neck; tail very short and rounded; a pale, indistinct line over the eye. Length, 4 inches.

Migratory. Arrives from the north in October and returns in the Spring. Next to the Hummingbird, the smallest bird we have. It is extremely shy, and, as Dr. Coues remarks, "less often seen than other Wrens no less common; voice strong and highly musical." 
PLATE LVIII. LONG.BILLEO MARSH WREN.

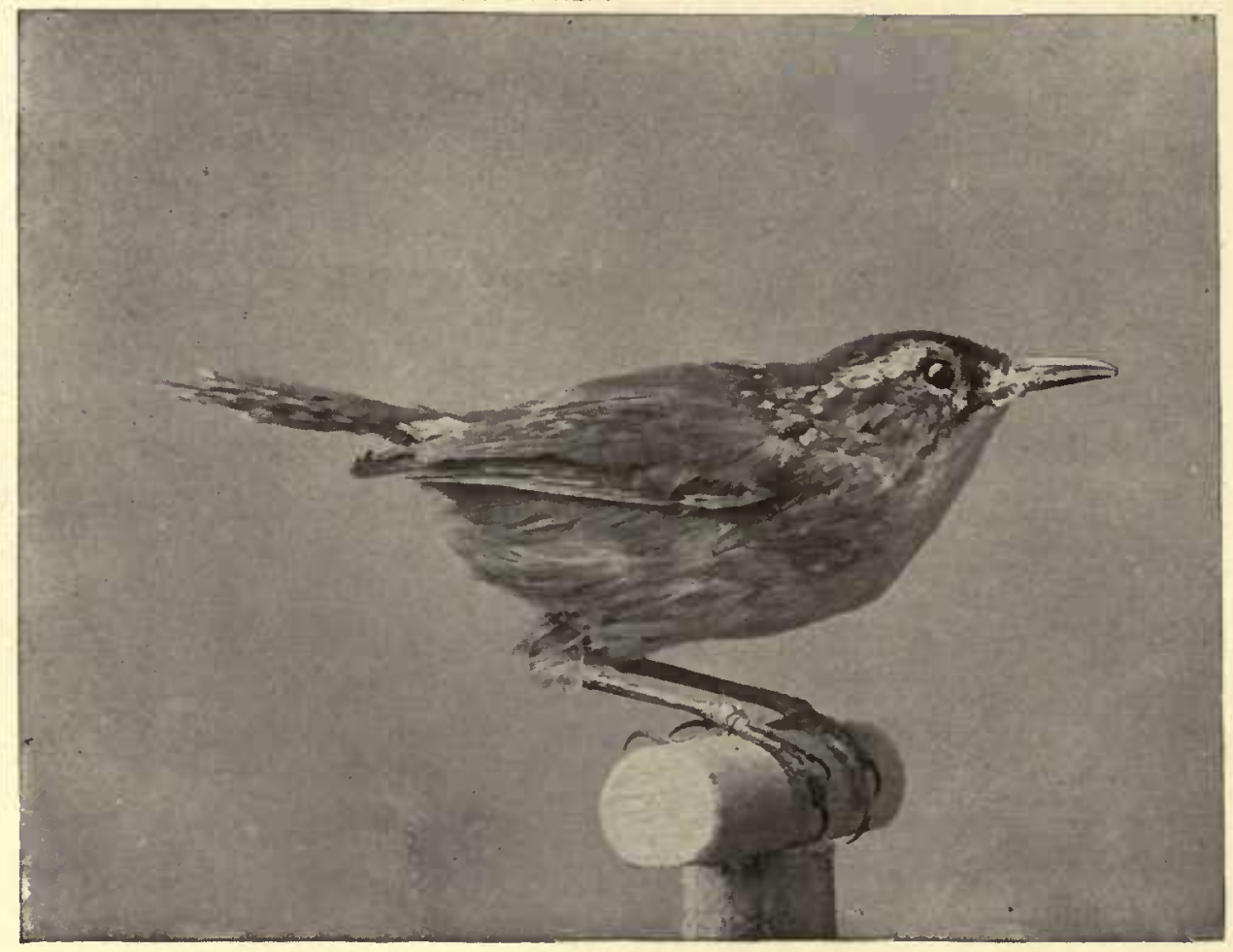




\section{PLATE LVIII.-LONG-BILLED MARSH WREN.}

Cistotborus palustris.

Above reddish-brown; head and back of the neck black, sometimes streaked with white; beneath white, shaded on the sides with brown; wings and tail much barred, the latter short and rounded; a pale streak over the eye. Length, 5.20 inches.

Migratory. Arrives late in May, leaves early in October. Builds a nest much like a cocoanut in size and shape, with a hole for entrance near the top. This it attaches to the reeds and rushes growing in swamps or marshes.

Wilson calls its song "a low, crackling sound, somewhat similar to that produced by air bubbles forcing their way through mud or boggy ground when trod upon."

DeKay more truthfully says that the bird is "highly musical," but adds, curiously enough, "It breeds ** probably (!) in this State (N.Y.), but I have not yet met with its nest." The writer has found the bird a very common one; he has seen many of its nests; and, in his judgment, its song is nearly as important as that of the House Wren, and somewhat similar to it.

At a junction of the railroad track which leads into Flushing, Long lsland, where 
many of the trains stop to be separated into sections, is a marsh inhabited by Marsh Wrens. The writer has often noticed the birds singing lustily at twelve o'clock in the night, and supposed that they were wakened by the noise of the cars. He is interested, therefore, in Dr. Mearns' statement that birds of this species have "the habit of singing at night when the moon is bright." He intends to learn if the Flushing colony sing when there is no moon. If he finds this to be the case, he will continue to ascribe the midnight serenade to the disturbing influence of the passing trains.

\section{HOUSE WREN.}

\section{Troglodytes aedon.}

Above reddish-brown, lighter towards the rump; beneath soiled white with brown tinges on the breast; wings and tail much barred, the latter rounded; a light line over the eye. Length, 5 inches.

Migratory. Arrives late in April, leaves middle of October. Nests in holes of stumps and fences, or in boxes which are often prepared for it in gardens, where it sometimes brings forth three broods.

He who studies the House Wren as it is seen about men's habitations, will say that it 
is a cheerful, industrious little creature, with charming confidence in mankind. He also will esteem it a persistent vocalist, with a trilling, gushing song of much sweetness and considerable length. And he will be right, if he limits the bird's possession of these good qualities to the breeding season. But this Wren is a bird of a dual character. While its household cares are upon it, the admirable traits predominate; but when the young have been sent forth, it lays aside the familiarity which had so endeared it to us, withdraws to some remote, barren and inaccessible spot, where, songless, secluded and aloof, wholly transformed in demeanor, it lurks among the tangled shrubbery until the time of its final departure. 
PLATE LIX. WHITE.BREASTED NUTHATCH.

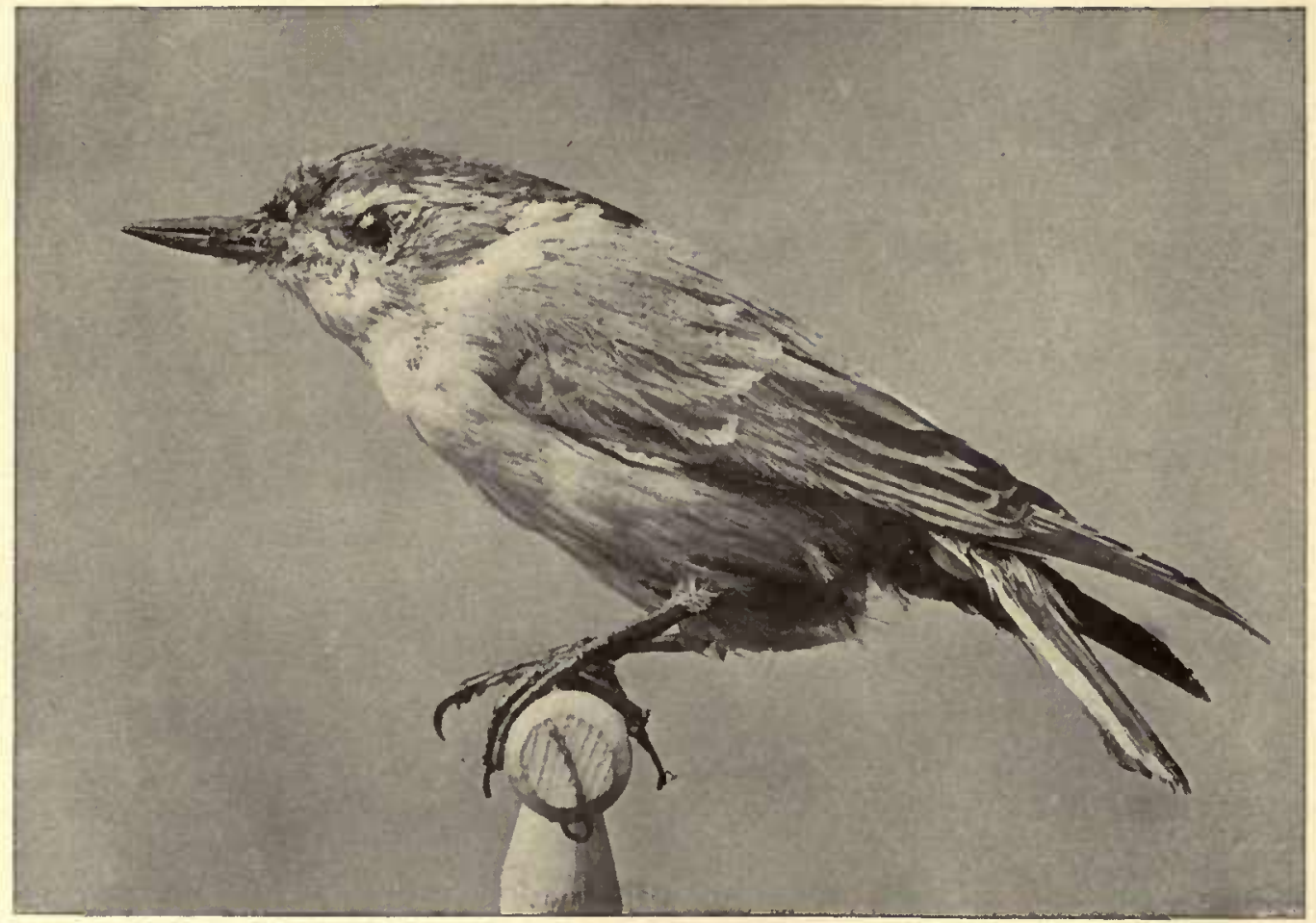




\section{PLATE LIX.-WHITE-BREASTED (OR BELLIED) NUTHATCH.}

\section{Sitta carolinensis.}

Crown and back of neck black; back gray-blue; cheeks, throat, breast and belly dull white; wings dark, many of the feathers lightedged; the middle feathers of the tail gray-blue, the outer ones marked strongly with black and white; bill and feet dark. Length, 6 inches.

Resident. Nests in a hole generally made by the bird itself in it tree or stump. It has no song, but utters a short, harsh call, which resembles the syllible quank. It clambers up, down or around tree-trunks, or runs along the upper or under side of a branch with equal ease, industriously searching for insects or nuts, on both of which it feeds.

In separating the kernels of nuts from the husk or shell, it wedges the nut into a crevice of bark or limb, and pounds upon it until the shell gives way.

The bird is an accomplished gymnast, hanging, says Dr. Coues, "in every conceivable attitude, head downward as often as otherwise." 
PLATE lX. ChICKadeE.

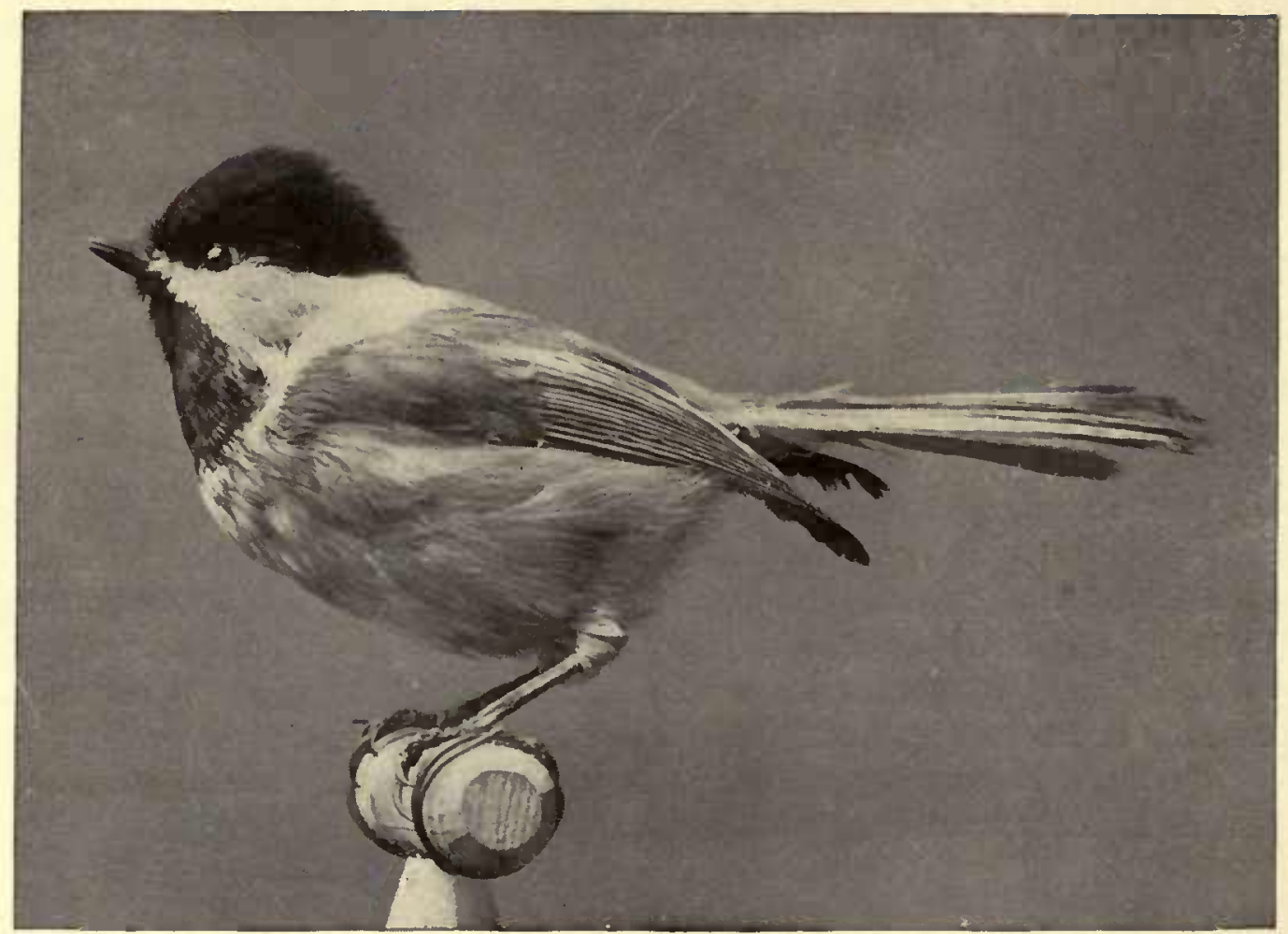




\section{PLATE LX.-CHICKADEE. BLACK-CAPPED TITMOUSE.}

\section{Parus atricapillus.}

Prevailing color gray-brown; crown and throat black; cheeks white; breast and belly dull white; tail nearly square; Length, 5.25 inches.

Resident. Nests in holes in trees or stumps. Flight wavering. A nervously active little fellow, constantly in motion. Fearless and confiding, it will pursue its avocations in close proximity to an observer, apparently unconscious of his presence. Its familiarity with man and confidence in him are very touching, and this trait, no less than its cheery call and industrious habits, endears it to all bird-lovers. It is often observed in company with Wrens and Nuthatches. In Fall and Winter the Chickadee is one of the most abundant birds we have, and it is then, perhaps, more frequently seen than any other kind. Its Summer call is cbick-a-dee-dee-dee-dee, and that of Winter is day-day-day. 
PLATE LXI. GOLDEN.CROWNED KINGLET.

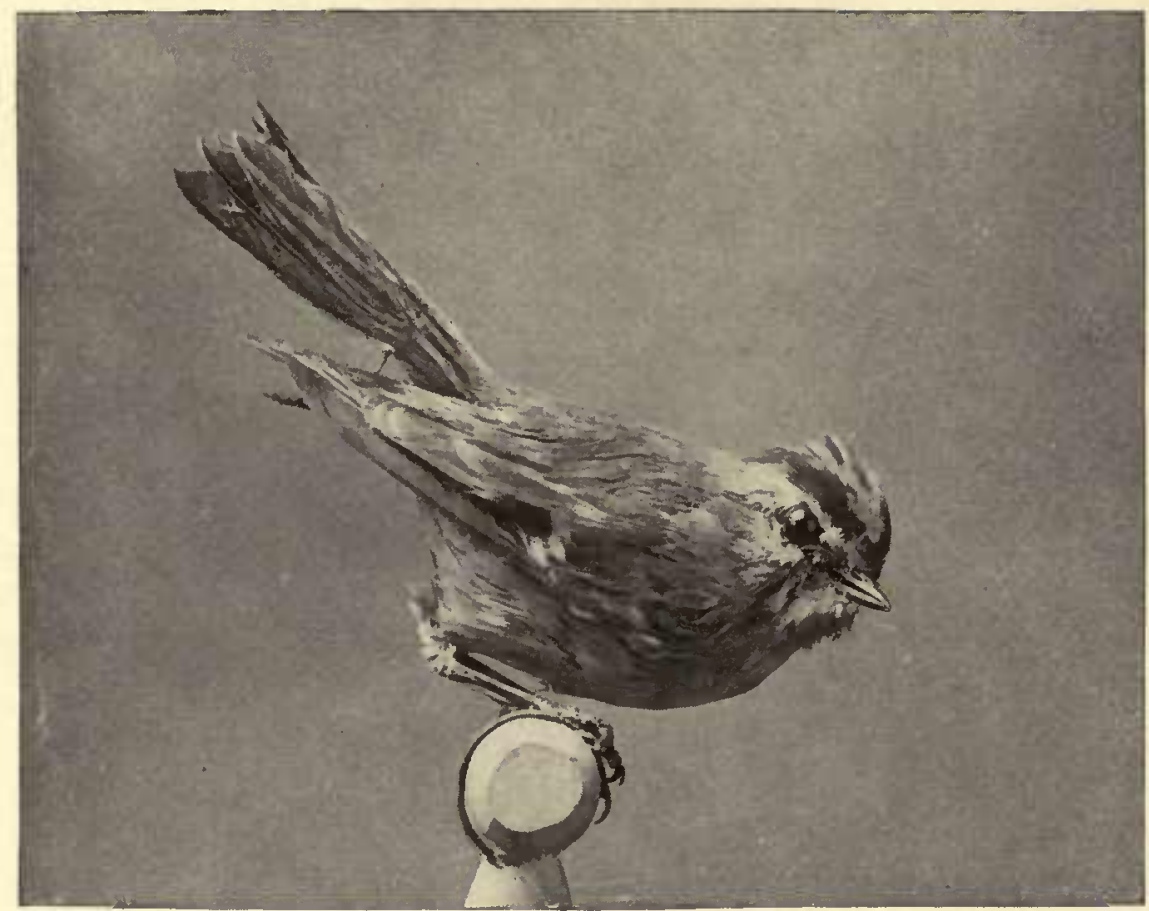




\section{PLATE LXI.-GOLDEN-CROWNED (OR CRESTED) KINGLET.}

\section{Regulus satrapa.}

Above olive-green; beneath dull white; crown as follows: in the centre a stripe of orange surrounded on front and sides by yellow, and that in the same manner by black, and that again similarly by light gray; wings brown, most of the feathers with pale edges; tail brown, notched; bill black; feet dark. Length, 4 inches.

Migratory. This exquisite little creature, fragile in appearance, and, excepting the Winter Wren and the Hummingbird, the tiniest of our birds, is, in fact, a hardy, coldloving species. It comes to us from the boreal regions about the first of October, and remains through the Winter. Look for it then among the pines and cedars. It has an artless little song, unpretentious but pleasing; a simple whistle repeated quickly three or four times. This it utters in a sort of antiphone to the day-day-day of the Chickadee, and the quank-quank of the Nuthatch, for these three birds are sworn friends and constant companions.

The Golden-crowned Kinglet is no lover of warm weather. Such experience as comes to him in the early Spring warns him to be off, and about May 1 he wends his way northward. 


\section{RUBY-CROWNED (OR CRESTED) KINGLET.}

Regulus calendula.

Much like the preceding, except that it is a trifle larger, the olivegreen of the back is darker, and the crown is as follows: general color olive-green, a vermilion patch in the centre, and the forehead light gray. Length, 4.40 inches.

Migratory. The habits of the Ruby-crowned Kinglet differ somewhat from those of its congener.

It hals a more southerly range, and spends its Winters in the south. It comes to us the middle of April, remains about one month, and then follows its Golden-crowned namesake. Whether or not it goes as far north, 1 do not know, but it is not again seen here until late in September. At this time, and about two weeks in advance of the Goldencrown, it pays us a month's visit, when it finally departs for its southern Winter home.

Dr. Mearns points out that this Kinglet " is one of our earliest singing migrants," and remarks that "its song is one of the sweetest, and much louder than would be supposed, coming from such a little bird." 


\section{HERMIT THRUSH.}

Turdus aonalascbka pallasii.

Above olive-brown, passing to a decidedly reddish color on the tail; beneath white, tinged with yellow on the breast, and with gray on the sides; throat pure white, bordered with brown spots, - these spots extend down upon the breast and are of a shape called arrow-headed; a yellowish ring around the eye; tail rather short, nearly even; bill dark brown,- - the lower mandible much the lighter; legs light brown. Length, 7.15 inches.

Migratory. Arrives early in April, leaves early in October. Nests near or on the ground. Its song is notable and resembles that of the Wood Thrush. Mr. Burroughs says: "The Wood Thrush and the Hermit stand at the head as songsters, no two persons, perhaps, agreeing as to which is the superior." Mr. Burroughs' own preference, however, is evident, for he mentions the "divine soprano of the Hermit," and again says: "A 
PLATE LXII. WOOD THRUSH.

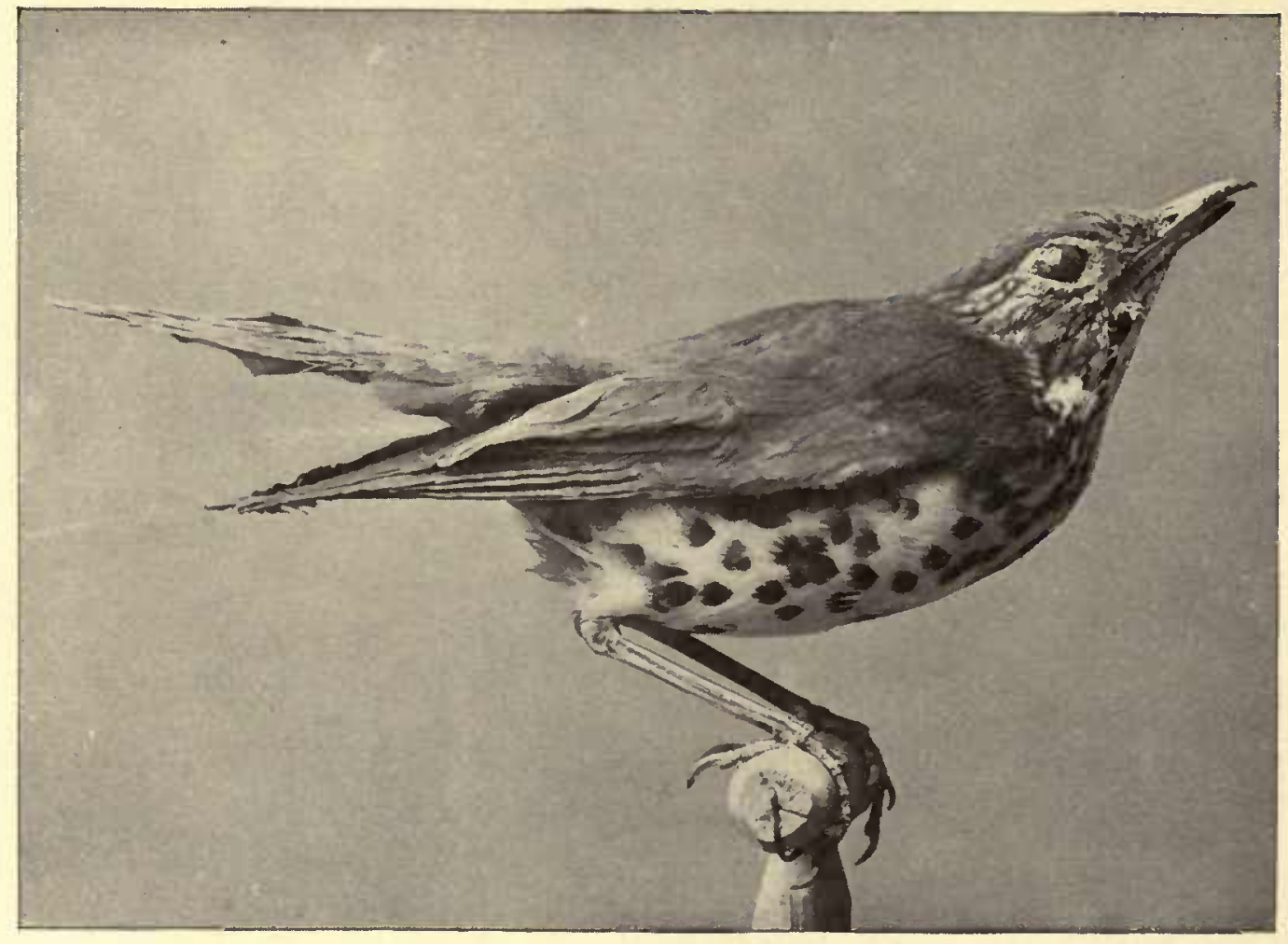


strain has reached my ears $* * *$ that to me is the finest sound in nature-the song of the Hermit Thrush."

The beginner will be puzzled to discriminate between the several Thrushes. As regards the three here mentioned, the Wood, the Veery and ine Hermit, the differences in the color of the back will guide him aright.

Miss Merriam thus concisely states these variations:

"The brown of the $W$ ood Thrush is reddest on the head and shoulders.

"The brown of the Hermit is reddest on the tail.

"The Tawny has a uniformly tawny back."

\section{PLATE LXII.-WOOD THRUSH.}

Turdus mustelinus.

Above cinnamon-brown, reddest on the bead, shading into olive on the rump and tail; beneath white, thickly spotted on breast and sides with dark-brown, but the chin, throat and middle of belly are immaculate; tail nearly even; bill brown; feet pale. Length, 8.25 inches.

Migratory. Arrives early in May, leaves late in September. Nests usually in woods, 
PLATE LXIII. WILSON'S THRUSH.

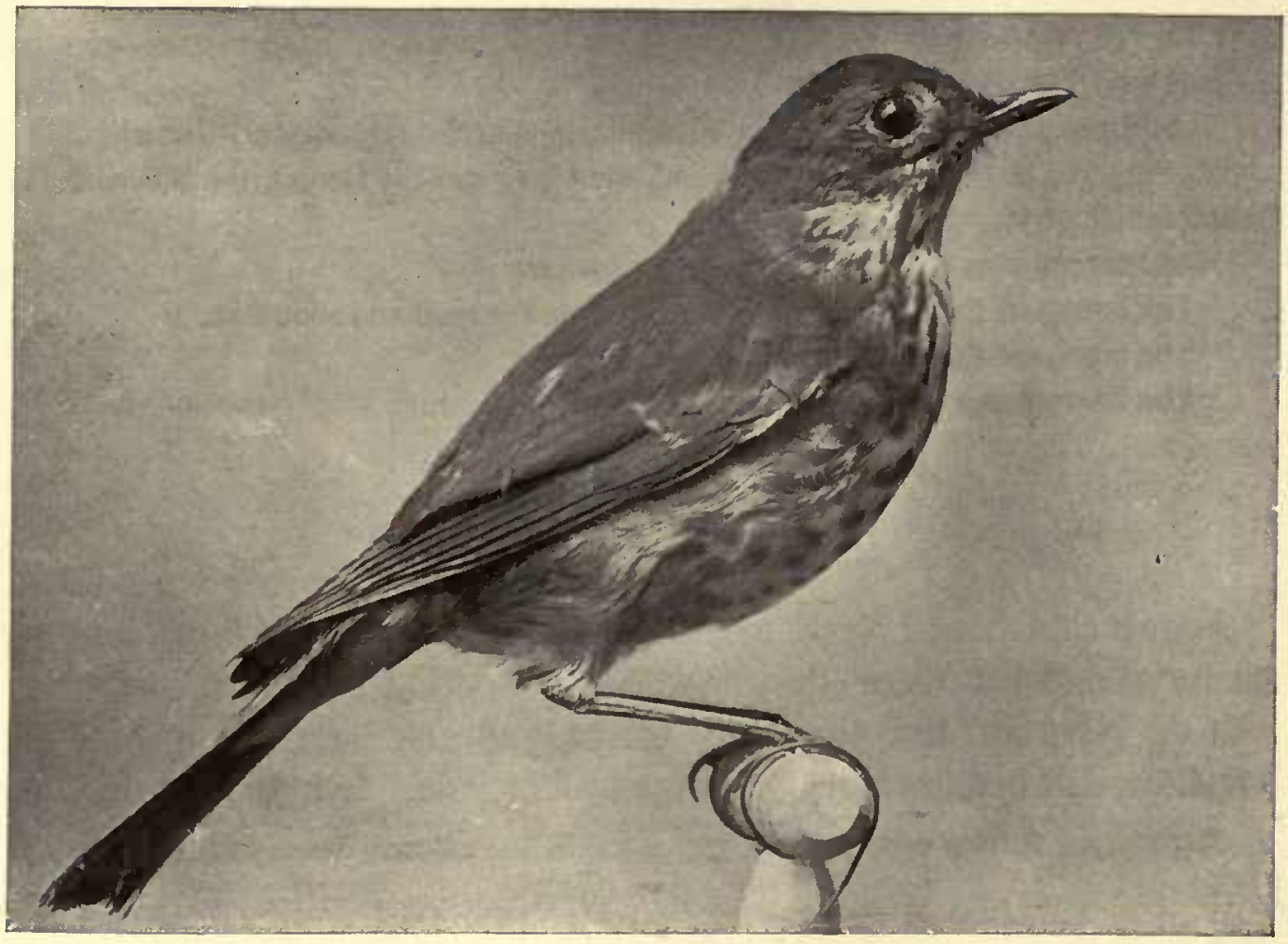


though trequently near dwellings, and seldom in lofty situations, preferring low trees or even bushes for its dwelling place.

Its song is one of the most beautiful of bird utterances ; strong, rich and varied, and with a peculiar metallic quality belonging to no other bird.

\section{PLATE LXIII.-WILSON'S THRUSH. TAWNY THRUSH. VEERY.}

\section{Turdus fuscescens.}

Above reddish-brown, nearly continuous $i n$ sbade, including tail; beneath white, less pure on sides, and even yellowish on throat and upper-breast; spotted with brown on the breast and sides of the throat; tail rather short and slightly notched; upper mandible darker than lower one; feet pale. Length, 7.50 inches.

Migratory. Arrives early in May, leaves early in September. Nests low, often upon the ground.

A shy bird, frequenting dark woods or swamps.

A fine singer. 
PLATE LXIV. AMERICAN ROBIN.

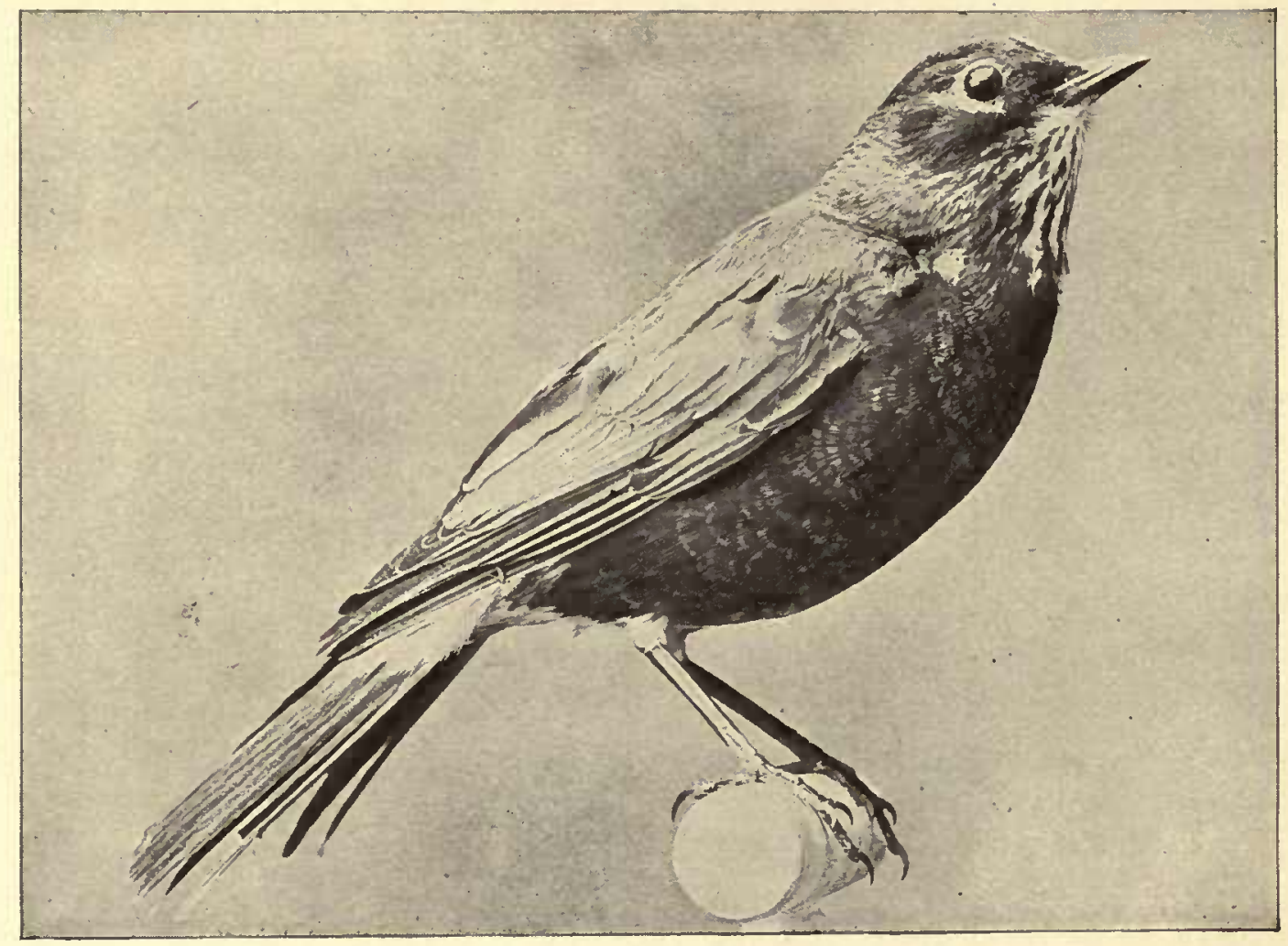




\section{PLATE LXIV.-AMERICAN ROBIN. ROBIN.}

Merula migratoria.

Above olive-gray; head black; throat white streaked with black; eye-lids and a spot before the eye white; breast and belly chestnutbrown; under-side of rump white; wings dark brown, some of the feathers with light edges; tail black, slightly rounded, the outside feathers tipped with white; bill yellow; feet dark. Length, ro inches.

A migratory species. Those individuals which sometimes pass the Winter here are probably birds with a more northerly range than the others of their kind. The Robin arrives in full force early in March and remains until late in the Fall.

Nests usually in trees, the structure being composed largely of mud.

During the breeding season a persistent vocalist, and if the song has not much variety, its heartiness and good cheer render it one of the most agreeable of bird utterances.

Many persons who cultivate cherries, grapes and other small fruits are prejudiced against the Robin, believing it to be destructive to their crops. Such enmity is ill-founded, for fruit is a small part of Robin's diet, and, by the havoc he creates among worms and 
insects, he much more than compensates for the damage done by his occasional lapses into vegetarianism. The quantity of worms and insects which he devours is enormous, indeed hardly credible. Professor Treadwell experimented on some young Robins kept in captivity, with a view of determining the amount of food necessary to maintain them, and found that each one required sixty-eight worms per day. That is to say, each bird "ate forty-one per cent. more than its own weight in twelve hours. The length of these worms, if laid end to end, would be about fourteen feet. Man at this rate would eat about seventy pounds of flesh a day, and drink five or six gallons of water."

Well may Mr. Thomas Wentworth Higginson, in OUT of DOoR PAPERs, exclaim at the "exhausting labor of yonder Robin, whose winged, picturesque day is spent in putting worms into insatiable beaks at the rate of one morsel in every three minutes."

The American Robin must not be confounded with the Robin Redbreast of English nursery tales. The two are not at all alike. The American Bluebird approaches most nearly of any of our birds to those which provided the celebrated sleeping babes with their leafy covering. 


\section{BLUEBIRD.}

Sialia sialis.

Above azure-blue; throat and upper-breast cinnamon; belly dull white; eyes large; tail and wings broad, the former slightly notched; bill and legs black. Length, 7 inches.

A migratory species; individuals, probably those with the northernmost range, being usually present with us through the Winter.

Arrives early in March or even in February, leaves late in November. Song a soft, pleasing warble in which a resemblance to the syllables tru-al-ly often repeated has been noticed. The bird utters this song when he is flying and when he is at rest.

Nests in holes of trees or posts, or in boxes placed for his use in gardens.

One of the earliest comers, the Bluebird is gladly welcomed as a harbinger of Spring, and his arrival is more widely remarked than that of most of the other birds. As the season advances and the tide of migration sets fully in, he loses his prominence. until, in Fall, many of the Summer visitors having departed, he again assumes importance; 
then, after greeting the Juncos and Snowflakes just come from the north, and bidding adieu to his intimate friends, the Chickadees, he joins the Kinglets and Warblers, now on their southern journey, and who tarry long enough for him to make his final preparations, and with them he seeks a sunnier clime. On some pleasant November morning, when we hear his sweet warble from an adjacent fence, though at the time we are unable to interpret the burden of his lay, he is, in his own "gentle, high-bred manner," bidding us

FAREWELL. 


\section{COLOR-GUIDE}

The following color-guide is intended to belp in identifying birds. To use it, scan the left column until a beading is found that indicates a color corresponding to the most noticeable marking of the bird whose name is desired. If, under tbis beading, there stand sub-beadings, see if the unknown bird bas peculiarities mentioned in one of these. The comparisons baving been accurately made, the reader may feel reasonably sure that be has reached the right name. Further confirmation may be sought from the descriptions in the body of the book, to which the figures in the rigbt column refer.

Back ash.

Bank SWallow.

KINGBIRD.

Back ash, streaked with black.

Head black; cheeks white.

BLACK-POLL W ARBLER.

Back black.

Head, neck and middle-breast black; sides of breast and tail-patches orange; belly white.

AMERICAN REDSTART.
PAGB Back black.

145

Belly white; sides chestnui.

CHEWINK.

Belly and rump white; breast rosered.

Rose-breasted Grosbeak.

137

Rump yellow.

Magnolia Warbler.

Back black and orange.

185

Baltimore ORIOle.

104 
Back black and white.

DOWNY WOODPECKER.

HAIRY WOODPECKER.

Breast orange.

BLACKBURNIAN WARBLER.

Head, and neck all round, crimson.

RED-HEADED WOODPECKER.

Back asby-blue.

NorTHERn SHRIKE.

Crested.

BELTED KingFISHER.

Throat, sides of head and of body black.

Black-Throated Blue WarBLER.

Crown and back of neck black; under-parts white.

White-BREastéd Nuthatch. 197
Back azure-blue.

PAGR

Breast cinnamon ; belly dull white.

BLUEBIRD.

Back ligbt blue.

Blue JaY.

A patch of yellow in centre of the back; breast yellow, somewhat spotted with brown.

PARULA WARBLER.

Back slaty-blue, streaked with black.

Crown, rump and a spot on each side of the breast yellow.

MYrTLE Warbler.

Back steel-blue.

Underneath chestnut.

Barn Swallow.

Back gray.

Least Flycatcher. 
Back olive-gray.

Head black; throat white streaked with black; breast and belly chestnut.

ROBIN.

Back olive-brown.

PHCEE.

WOOd PEWEe.

Beneath white with many brown spots.

Hermit Thrush.

Back melallic-green.

RUbY-Throat'd Humm'g Bird. 78

Back olive-green.

Great Crested Flycatcher. 83

KINGLETS (very small birds).

201,202

Beneath white, spotted and streaked with black.

OVEN-BIRD.
Back olive-green.

PAGR

Beneath yellow (more or less pure).

Maryland Yellow-Throat, 180

Yellow-bellied Flycatcher. 87

Yellow-Breasted Chat. $18 \mathrm{I}$

Yellow-Throated Vireo. 151

Eyes red.

RED-EYED VIREO.

Eyes white.

White-eyed ViReo. 157

Head blue-gray.

SOLITARY VIREO.

155

Head buff, striped with black.

WORM-EATING W ARBLER. 160

Back olive-yellow.

Forehead, cheeks, breast and belly bright yellow; neck all round, crown and chin black.

HOODED WARBLER. 
Back reddish-brown.

Beneath white spotted with brown.

Brown THRasher.

WILSON'S THRUSH.

WOOd THRUSH.

Back slate, streaked with black.

Throat and sides chestnut; belly and centre of breast reddish-white. BAY-BREASTED WARBLER.

Back sooty-brown.

Throat light gray.

$$
\text { Chimney SWift. }
$$

Back wbite.

Hind-neck cream color; all else black. BoBolink (in nuptial plumage). 95

Back yellowish-green.

Chin, throat and breast black; forehead, a band over the eye, cheeks and sides of neck yellow.

Black-throated Green WarBLER.
Beneatb wbite (more or less pure).

Cuckoos. 61,62

DOWNY WOODPECKER.

HAIRY WOODPECKER.

KINGBIRD.

Least Flycatcher.

NORTHERN SHRIKE.

PHCEBE.

ReD-HEADED WOODPECKER. 71

White-BREasted Nuthatch. 197

Wood Pewee.

A brown band across the breast.

Bank SWallow.

Sides chestnut.

Chewink.

Streaked on sides of body with black.

Black AND White Warbi.er. 159

Streaked on sides of body with black ; head black; cheeks white.

BLACK-POLL Warbler. 
Beneatb white (more or less pure).

Throat, sides of head and of body

black; back grayish-blue.

Black-throated Blue WarBLER.

A chestnut stripe on each side of the body.

$$
\text { Chestnut-sided W Arbler. }
$$

171

Spotted with brown or black on breast and belly.

BROWN THRASHER.

OVEN-BIRD.

189

Thrushes (Hermit, Wilson's and WoOD). 203-207

Breast or belly (or botb) brigbt orange.

Baltimore OrIOle.

Blackburnian Warbler.

Breast or belly (or botb) chestnut.

Barn Swallow.

BLUEBIRD.
Breast or belly (or botb) cbestmut.

Orchard Oriole.

ROBIN.

Breast rose-red.

Belly white.

Rose-breasted Grosbrak. 137

Breast or belly (or botb) spotted or dasbed.

BROWN THRASHER.

FLICKER.

Fox SPARROW. 131

HORnED LaRK. 93

OVEN-BIRD.

Thrushes (Hermit, Wilson's and WOOD). 203-207

Breast or belly (or botb) more or less yellow.

AMERICAN GOLDFINCH.

I 12

Great Crested Flycatcher. 83

Maryland Yellow-Throat. I80

ParUla Warbler. 161

RED-EYED VIREO.

153 
Breast or belly (or botb) more or less ${ }^{\mathrm{PAGB}}$ yellow.

Yellow-bellied Flycatcher. 87

Yellow-Bellied Sapsucker. 69

Yellow-BREASTED Chat. I8I

YELLOW-THROATED VIREO. 151

YeLLOW WARBLER.

Crown bay.

Palm Warbler.

Forehead and cheeks yellow; neck all round, crown and chin black.

HOODED W ARBLER.

184

Large black crescent on neck.

MEADOWLaRK.

101

Throat, chin and rump yellow; back black; black streaks on breast and sides of body.

Magnolia Warbler.
Breast lilac-brown, with a large, black PAGR balf-moon.

Belly ashy, plentifully spotted with black; rump white.

FLICKER.

Crested (more or less).

Belted Kingfisher.

Blue Jay.

Cardinal.

Cedar Waxwing.

147

Great Crested Flycatcher. 83

KINGBIRD.

$8 \mathrm{~J}$

PHCEBE.

85

Wood Pewee.

85

General color ash.

Head crested; tail with a yellow terminal band.

Cedar Waxwing. 
General color black.

CowrIRD.

Crow.

Purple Grackle.

Shoulders red.

RED-WINGED BLACKBIRD.

Sides of body chestnut.

Chewink.

Tail-patches and sides of breast orange; belly white.

American Redstart.

General color blue.

INDIGo BunTING.

Crested.

\section{BELTED KingFisher.}

Blue Jay.

Breast cinnamon; belly dull white.

BLUEBIRD

Underneath chestnut.

BARn SWALlow.

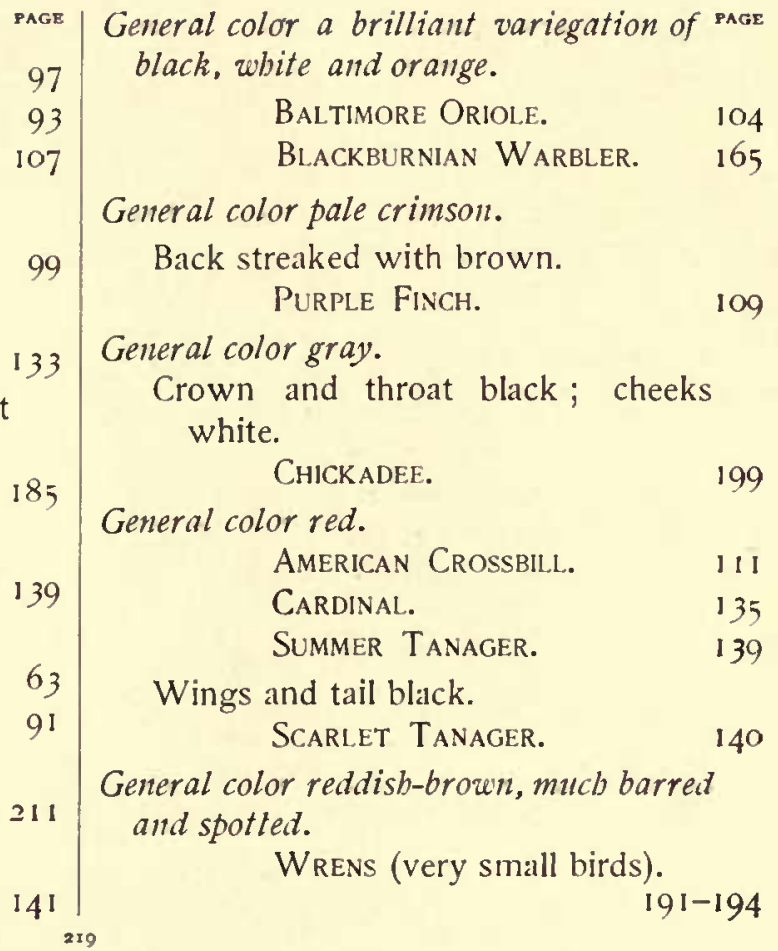


General color slate.

Belly white; tail with white outside feathers.

$$
\text { JUNCO. }
$$

Crown and tail black.

$$
\text { CATBIRD. }
$$

General color sireaked with brown (or reddisb) and dull white (or yellowish).

Chipping Sparrow.

Field Sparrow.

Fox Sparrow.

PINe Siskin.

Song Sparrow.

Chin white.

White-THROATED SPARROW. 12 I

Shoulders reddish; outer tail-feathers white.

Vesper Sparrow.

Shoulders yellow.

GrasshopPer SPARROW.
PAGB General color wbite.

SNOWFLAKE.

PAGE

General color yellow.

Crown, wings and tail black.

AMERICAN GOLDFINCH.

Under-parts streaked with reddishbrown.

YELLOW WARBLER.

Head and neck all round bright crimson. Back black; rump white. RED-HEADED WOODPECKER. 71

Tail with a white terminal band. KINGBIRD.

Tail with a yellow termunal band. Cedar Waxwing.

Throat ruby-red.

Back metallic-green.

Ruby-throat'd Humm'G BiRd. $j 8$ 


\section{INDEX}

BeE-MARTIN, see Kingbird.

Black BIRD, Crow (or Common Crow), see Purple Grackle. Marsh (or Swamp), see Red-winged Blackbird. Red-winged, 30, 35, 40, 48, 99. PI. XXI. Skunk, see Bobolink.

Bluebird, 31, 34, 35, 40, 50, 211.

ВовоLInk, 3I, 37, 39, 48, 95. Pl. XIX.

Bunting, Bay-winged, see Vesper Sparrow.

Indigo, 31, 32, 37, 39, 48, 139.

Snow, see Snowflake.

Towhee, see Towhee.

Yellow-winged, see Grasshopper Sparrow.

BUTCHER-BIRD, see Northern Shrike.

Cardinal, 23, 37, 48, 135. Pl. XXXV1.

Catbird, 31, 36, 39, 50, 187. PI. LV.

Cedarbird, see Cedar Waxwing.

Chat, Yellow-breasted, 36, 38, 49, 181 .

Chebec, see Least Flycatcher.

Cherrybird, see Cedar Waxwing.
Chewink, see Towhee.

Chickadee, 31, 34, 50, 199. Pl. LX.

Chippy, see Chipping Sparrow.

ClaPE, see Flicker.

CowbIRd, 35, 39, 48, 97, 163. Pl. XX.

CREEPER (or Creeping Warbler), Black and White, see Black and White Warbler.

Crossbill, American (or Red), 34, 36, 48, 111 . PI. XXVI.

Crow, American, 30, 34, 47, 81, 93. PI. XVIll.

Cucкoo, Black-billed, 21 , 23, 31, 37, 39, 46, 6́1. Pl. IV.

Yellow-billed, 46, 62.

Finch, Grass, see Vesper Sparrow.

Pine, see Pine Siskin.

Purple, 34, 35, 40, 48, 109. P\}. XXV.

FirEBIRD, see Baltimore Oriole.

Flicker, 31, 34, 35, 40, 46, 73. IP. IX.

Flycatcher, Great Crested, 37, 39, 47, 83. PI. XIII.

Least, 37, 39, 47, 89. Pl. XVI.

Yellow-bellied, $37,38,47,87$. Pl. XV. 


\section{Index}

Goldfinch, American, 31, 32, 34, 48, 112.

Grackle, Purple, 35, 40, 48, 107. PI. XXIV

Greenlet, see Vireo.

Grosaeak, Cardinal, see Cardinal.

Rose-breasted, 36, 39, 48, 137. PI. XXXVII.

HaIr-BIRo, see Chipping Sparrow.

Hangnest, see Baltimore Oriole.

HIGH-HOLE (or High-holder), see Flicker.

Hummingeiro, Ruby-throated, $31,37,38,47,78$.

INDIGO-BIRD, see Indigo Bunting.

Jay, Blue, 31, 34, 47, 91. PI. XVII.

Junco, (or Slate-colored Junco), 48, 127. PI. XXXI1.

Kingbird, $36,38,47,81$. PI. XIl.

Kingfisher, Belted, 23, 31, 34, 35, 46, 63. Pl. V.

Kinclet, Golden-crowned (or crested), 34, 36, 39, 50, 201. Pl. LXI.

Ruby-crowned (or crested), 35, 36, 39, 50, 202.

LARK, Horned, 34, 35, 39, 47, 93.

Linnet, Pine, see Pine Siskin.
LETTUCE-BIRD, see American Goldfinch.

Meadowlark, 31, 34, 35, 40, 48, 101. PI. XXII.

MEADOW-Wink, see Bobolink.

MYRTLEBIRD, see Myrtle Warbler.

Night-jar, see Whip-poor-will.

Nuthatch, White-breasted (or bellied), 34, 50, 197. PI. LIX

Old Fieldlark, see Meadowlark.

OrIOLE, Baltimore, 31, 36, 38, 48, 104 .

Orchard, $37,39,48,103$. PI. XXIII.

OVEN-BIRO, 36, 40, 49, 183. Pl. LIV.

OwL, Great Horned (or Hoot, or Cat), 34, 46, 57. P1. II.

Little Horned (or Mottled, or Red, or Screech), $34,46,59$.

Saw-whet (or Acadian), 34, 46, 55. Pl. 1.

Snowy, 34, 35, 46, 59. PI. III.

PEABODY-BIRD, see White-throated Sparrow.

Pewee, Water, see Phobe.

Wood, 37, 39, 47, 85 .

Pewit Flycatcher, see Phobe. 


\section{Index}

Phсев, $35,40,47,85$. Pl. XIV.

ReEdBird, see Bobolink.

Reobird, Summer, see Summer Tanager.

Redstart, American, 36, 39, 49, 185.

RICEBIRD, see Bobolink.

Robin, American, 30, 34, 35, 40, 50, 209. Pl. LXIV.

Golden, see Baltimore Oriole.

Ground, see Towhee.

SAPSUCKER, Yellow-bellied, 23, 35, 40, 46, 69. PI. VIl.

SHrike, Northern, 23, 34, 35, 40, 49, 149. Pl. XLIl.

Siskin, Pine, $34,35,39,48,115 . \quad$ PI. XXVII.

SNowbird, see Junco.

SNowflake, 34, 35, 40, 48, 117 . Pl. XXVIII.

Sparrow, Chipping, 36, 40, 48, 125. PI. XXXI.

Field, 36, 40, 48, 117 .

Fox, $35,36,40,48,131$. PI. XXXIV.

Grasshopper (or Yellow-winged), 36, 39, 48, 123.

Song, 31, 33, 35, 40, 48, 129. Pl. XXXIll.

Vesper, 35, 40, 48, 119 . PI. XXIX.

White-throated, 34, 36, 37, 39, 48, 121. PI. XXX.
Swalıow, Bank, 36, 38, 49, 145. Pl. XL.

Barn, 31, 36, 38, 49, 141. Pl. XXXIX.

Chimney, should be Chimney Swift q. v.

SwIFT, Chimney, 31, 36, 39, 47, 77. Pl. XI.

Tanager, Scarlet, $31,37,39,48,140$.

Summer, 31, 48, 139. PI. XXXVIII.

Thistle-BIRo, see American Goldfinch.

Thrasher (or Thrush), Brown, 36, 39, 50, 189. Pl. LVI.

Thrush, Golden-crowned, see Oven-bird.

Hermit, 35, 37, 39, 50, 203, 205.

Red, see Brown Thrasher.

Wilson's (or Tawny), 36, 38, 50, 205, 207. PI. LXIII.

Wood (or Song), 36, 39, 50, 205. PI. LXII.

Tıtmouse, Black-capped, see Chickadee.

TOWHEE, 36, 40, 48, 133. Pl. $\mathrm{XXXV}$.

VEERY, see Wilson's Thrush.

VIKEO, Blue-headed (or Solitary, 36, 39, 49, 155. PI. XLIV.

Red-eyed, 37, 39, 49, 153. PI. XLIII.

White-eyed, 36, 39, 49, 157. Pl. XLV. 


\section{Index}

VIREO, Yellow-throated, $36,39,49,151$.

Warbler, Bay-breasted, 37, 39, 49, 173. Pl. L.

Black and White, 36, 39, 49, 159. Pl. XLVI.

Black and Yellow, see Magnolia Warbler.

Blackburnian, 37, 38, 49, 165.

Black-poll, 37, 40, 49, 175. Pl. LI.

Black-throated Blue, 36, 39, 49, I 67. Pl. XLVII.

Black-throated Green, 37, 40, 49, 177. Pl. Lll.

Blue Yellow-backed, see Myrtle Warbler.

Chestnut-sided, 36, 39, 49, 171. PI. XLIX.

Hooded, 37, 38, 49, 184 .

Magnolia, 37, 38, 49; 169. PI. XLVIII.

Myrtle, 35, 38, 39, 49, 164 .

Palm, 36, 39, 49, 179, PI. Llll.

Parula, 36, 39, 49, 16 .

Worm-eating, 37, 39, 49, 160.

Yellow, 36, 37, 49, 162.

Yellow Red-poll, see Palm Warbler.

Yellow-rumped, see Myrtle Warbler.

Waxwing, Cedar, 31, 34, 49, 147. Pl. XLI.

WHIP-POOR-WILL, 36, 38, 46, 75. Pl. X.

WOODPECKER, DoWnY, 34, 46, 67 .

Golden-winged, see Flicker.

Hairy, 34, 46, 67. PI. VI.

Pigeon, see Flicker.

Red-headed, 35, 39, 46, 71. PI. VIII.

Yellow-bellied, see Yellow-bellied Sapsucker.

WREN, Golden-crowned (or crested), see Golden-crowned

Kinglet.

House, 31, 36, 39, 50, 194.

Long-billed Marsh, 37, 39, 50, 193. PI. LVIIl.

Ruby-crowned (or crested), see Ruby-crowned

Kinglet.

Winter, 34, 36, 39, 50, 191. Pl. LVII.

YellowBIRD, see American Goldfinch.

Summer, see Yellow-Warbler.

Yellowthront, Maryland, 23, 37, 40, 49, 180.

Yucker (or Yellowhammer), see Flicker. 


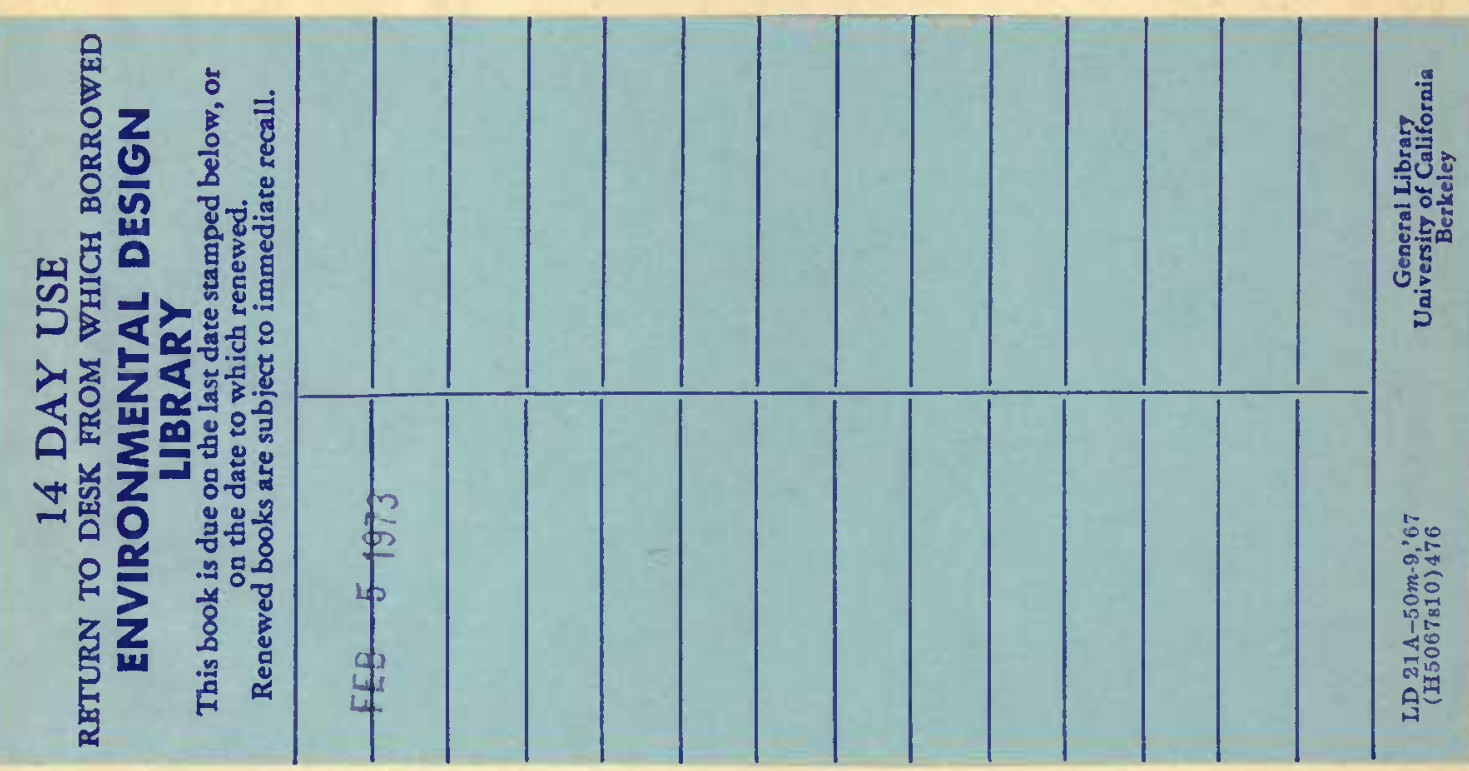




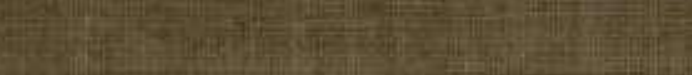

Io

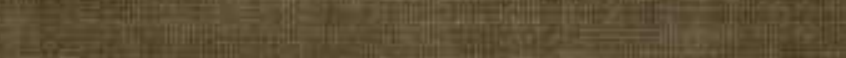

(t)

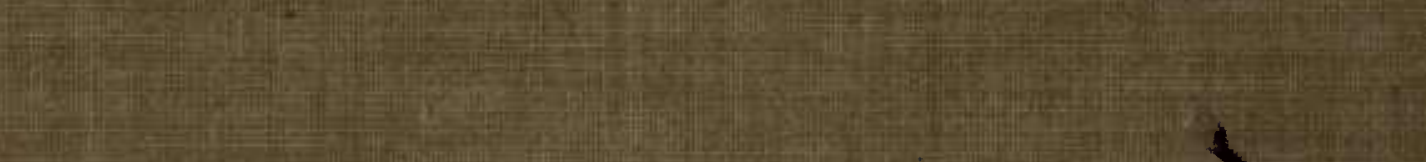

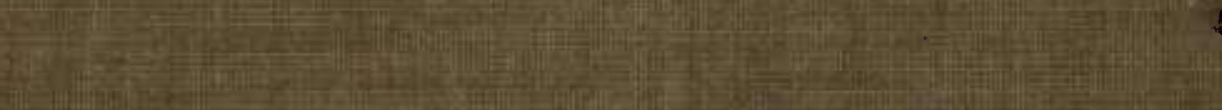

(1.60)

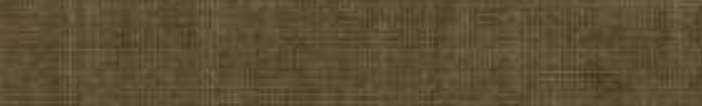

If

Cill

cind

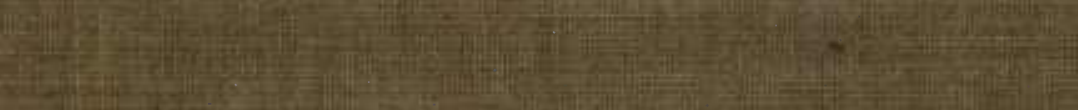

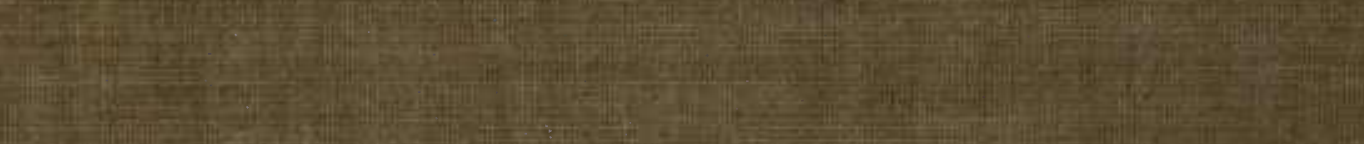

1.

If

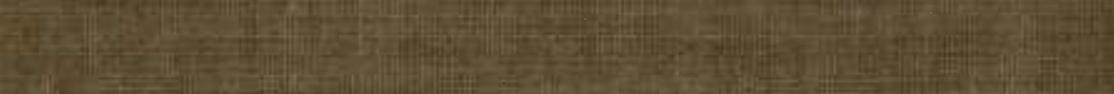

Whing

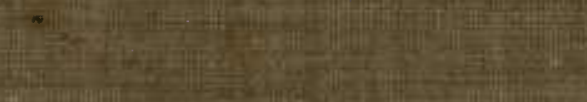

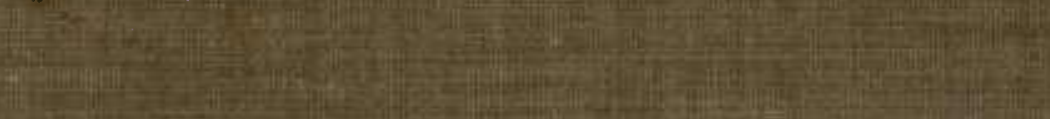

(1)

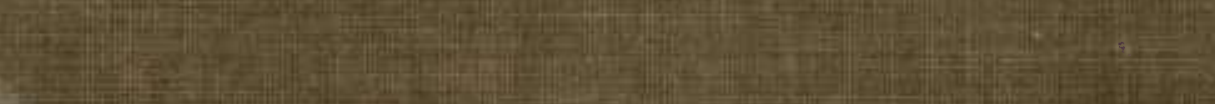

